\author{
UNIVERSIDAD AUTÓNOMA METROPOLITANA \\ UNIDAD IZTAPALAPA \\ DIVISIÓN DE CIENCIAS BIOLÓGICAS Y DE LA SALUD
}

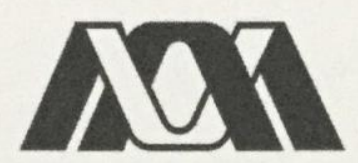

Casa abierta al tiempo

Endopoligalacturonasa de Kluyveromyces marxianus CDBBL-278: Un estudio comparativo de la expresión del gen y de la actividad enzimática bajo condiciones aerobias y anaerobias.

\title{
TESIS
}

Para obtener el grado de

Doctora en Biotecnología

PRESENTA

M en C. Alicia Rivera Noriega

Director

Dr. José Mariano García Garibay

Ciudad de México

21 de Noviembre de 2017

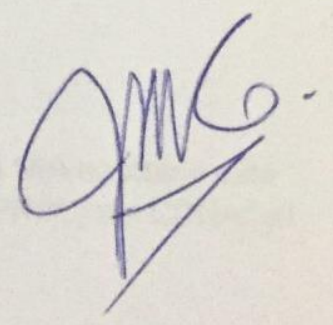




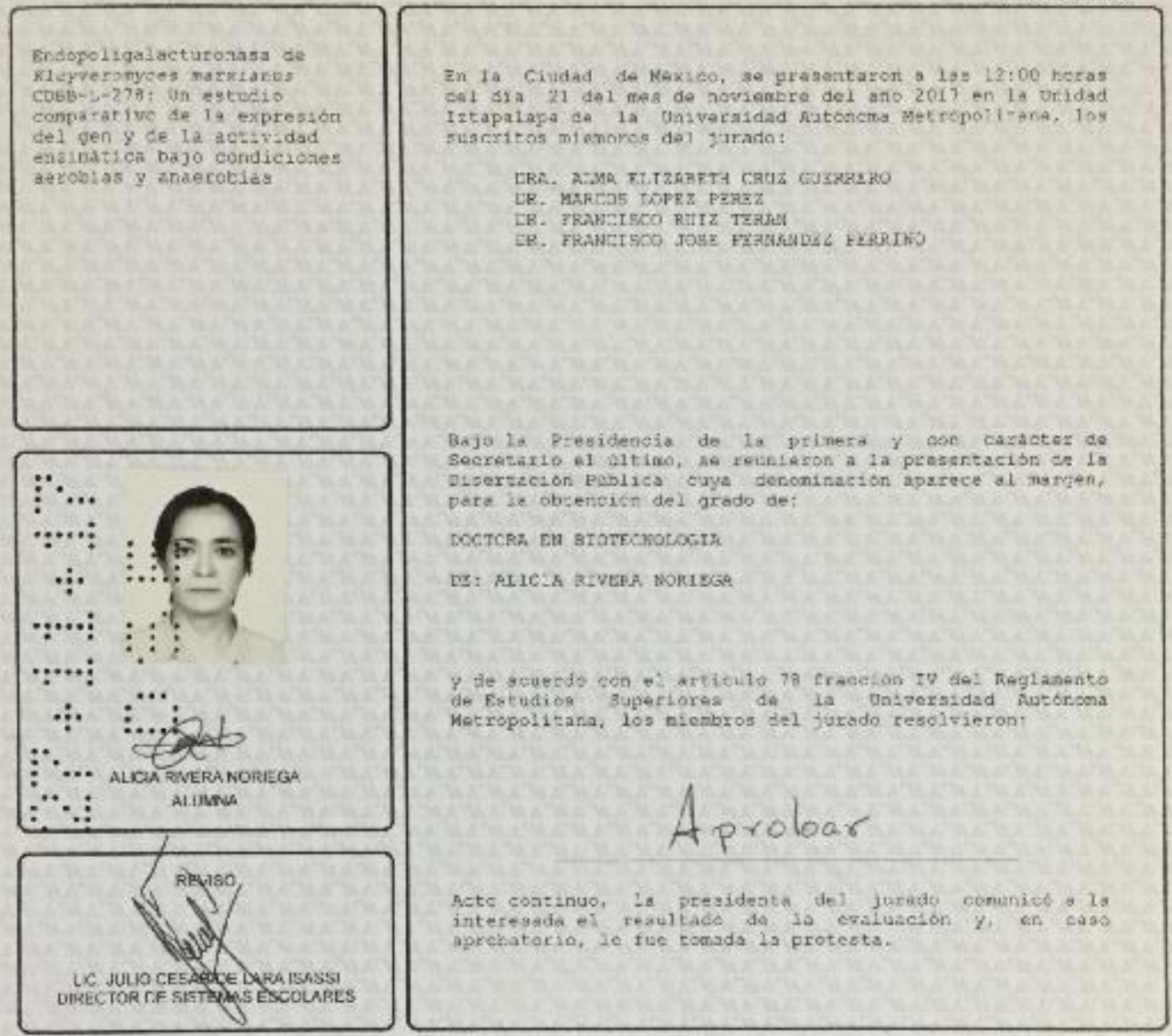

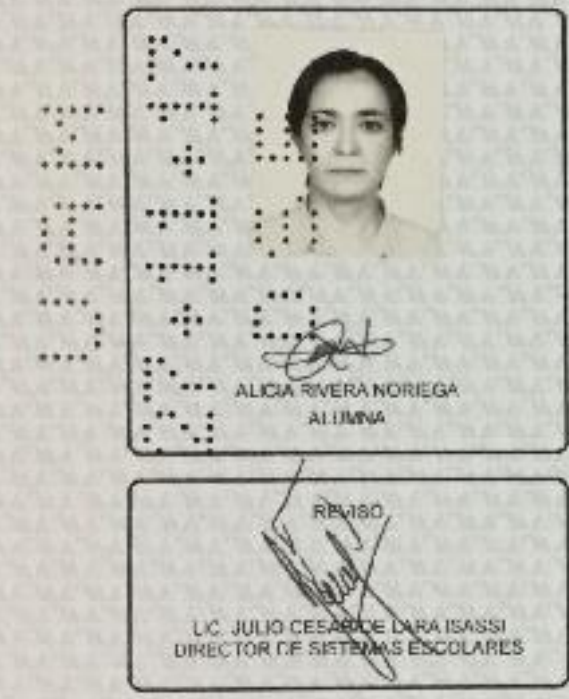
DOCTCRA EU BTOTECNOLOCIR

DE: AIIELS RLVEFA NORIEGS

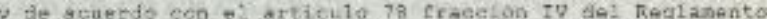

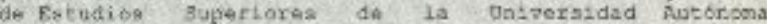
hetropolitana, loo nienbros del juxado resolifieroni
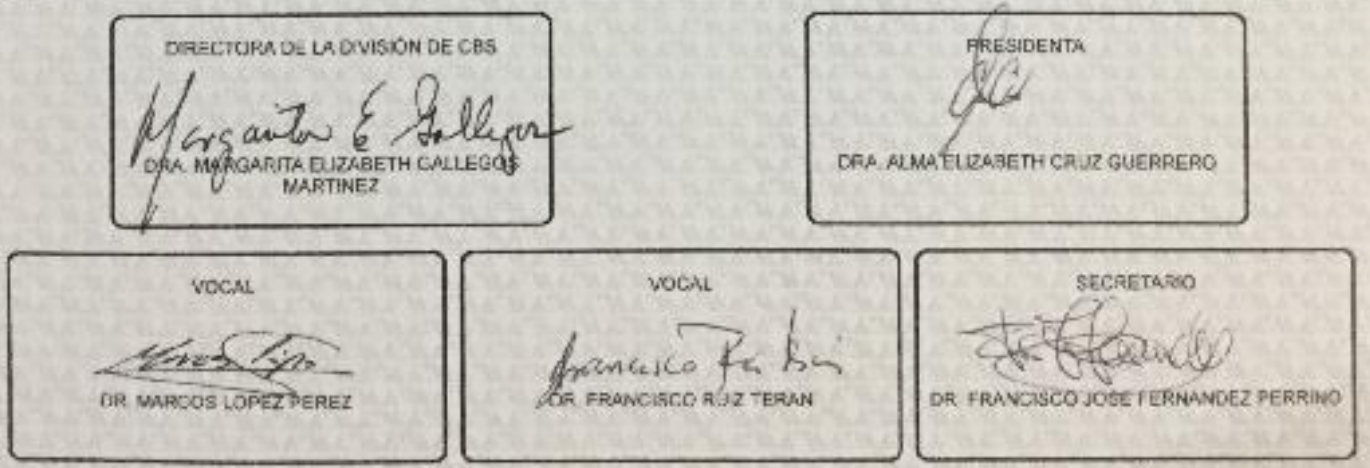
El Doctorado en biotecnología de la Universidad Autónoma Metropolitana está incluido en el Programa Nacional de Posgrados de Calidad (PNPC) del CONACyT, con la referencia 001466 
El jurado designado por la División de Ciencias Biológicas y de la Salud de la Unidad Iztapalapa aprobó la tesis

\section{ENDOPOLIGALACTURONASA DE Kluyveromyces marxianus CDBB-L-278: UN ESTUDIO COMPARATIVO DE LA EXPRESIÓN DEL GEN Y DE LA ACTIVIDAD ENZIMÁTICA BAJO CONDICIONES AEROBIAS Y ANAEROBIAS}

\section{Que presentó}

\section{Alicia Rivera Noriega}

\section{COMITÉ TUTORAL:}

Director: Dr. José Mariano García Garibay Asesor: Dra. Alma Elizabeth Cruz Guerrero Asesor: Dr. Marcos López Pérez

JURADO:

Presidente: Dra. Alma Elizabeth Cruz Guerrero

Secretario: Dr. Francisco José Fernández Perrino

Vocal: Dr. Marcos López Pérez

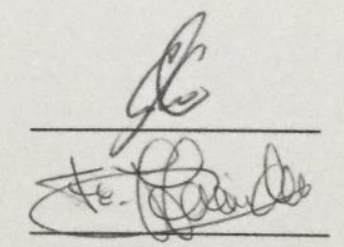

Vocal: Dr. Francisco Ruiz Terán

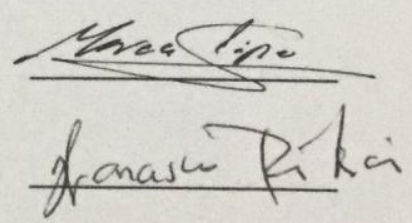


AGRADECIMIENTOS

A mi Director de Tesis, el Dr. José Mariano García Garibay, por confiar en mí para la realización de este proyecto, por su orientación y consejos para mejorar mi trabajo como investigador.

Al Dr. Francisco José Fernández Perrino y Marcos López Pérez por la orientación brindada en los experimentos de biología molecular.

A los Doctores Alma Elizabeth Cruz Guerrero, Francisco José Fernández Perrino, Marcos López Pérez y Francisco Ruíz Terán por el tiempo dedicado en la revisión de esta tesis.

A los Doctores Gabriela Rodríguez Serrano y Sergio Alatorre Santamaria, a la Maestra Lorena Gómez Ruiz, por el apoyo brindado durante mi estancia en la PP2.

Al Dr. Guillermo Aguilar Osorio de la Facultad de Química de la UNAM, por permitirme trabajar en su laboratorio y apoyarme en todo lo que necesite durante mi estancia.

A mis compañeros de la PP2, con quienes en ocasiones pasaba más tiempo que con mi familia, por la convivencia.

A mis padres José Luis Rivera Morúa y Eustolia Noriega Alvarado quienes me siguen apoyando con amor y paciencia, por todas las enseñanzas de vida. A mis hermanos por sus consejos y apoyo siempre que los necesito.

A mis amig@s de toda la vida porque a pesar de la distancia siguen pendientes de nuestro caminar.

A mi esposo Jorge Augusto Ríos Durán y a mis hijos Vale y Abi, quienes soportan mis numerosas ausencias con amor y paciencia, quienes están ahí para apoyarme, consolarme y alentarme cuando las cosas no marchan bien. "Los amo hasta el cielo, las estrellas, el infinito y más para allá" 


\section{INDICE}

\section{RESUMEN}

\section{ABSTRACT}

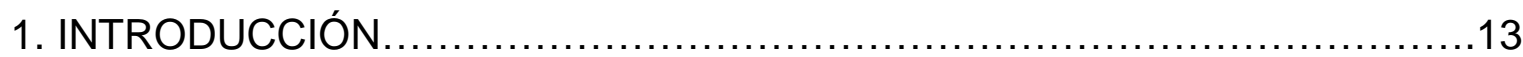

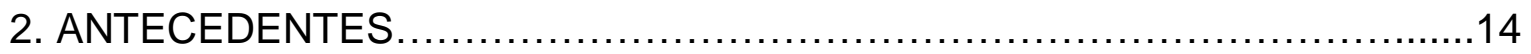

2.1 Kluyveromyces marxianus.......................................... 14

2.2 Kluyveromyces marxianus CDBBL-278............................. 15

2.3 Pectinas y enzimas pectinolíticas....................................15

2.4 Endopoligalacturonasas (endo-PG) en levaduras.....................18

2.5 Genes de pectinasas en K. marxinus ...............................21

2.6 Estudio de la expresión de genes.....................................22

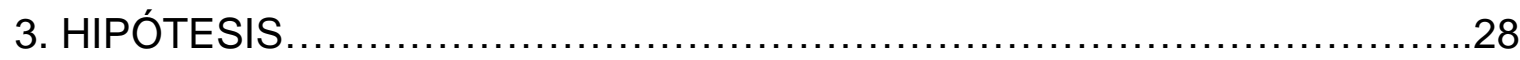

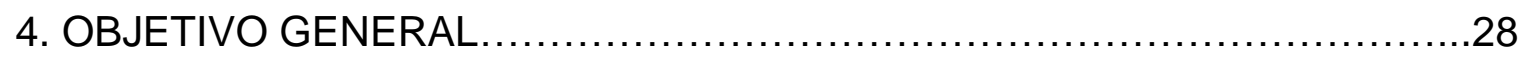

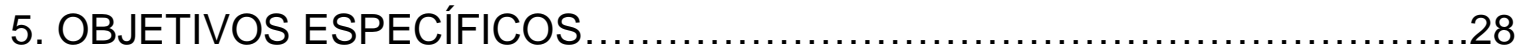

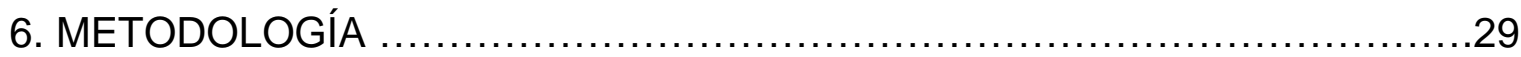

\subsection{ESTRATEGIA EXPERIMENTAL}

6.1.1 Aislamiento e identificación del gen de la endo-PG en la cepa $K$.

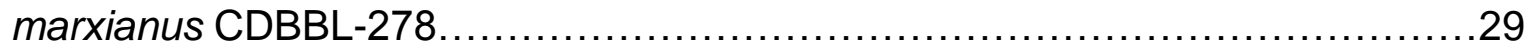

6.1.2 Cuantificación del gen de la endo-PG mediante PCR cuantitativa bajo diferentes condiciones de crecimiento (oxígeno disuelto) .......................30

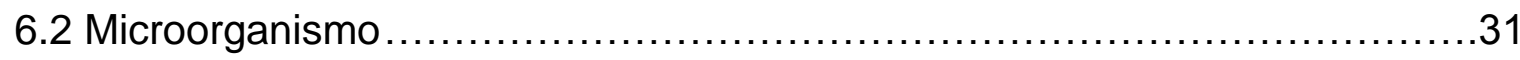

6.3 Identificación del gen que codifica para la endo-PG de la cepa de $K$. marxianus CDBB-L-278 
6.3.1 Preparación del paquete celular.....

6.3.2 Extracción de DNA ...............................................

6.3.3 Amplificación del gen que codifica para endo-PG...................33

6.3.4 Secuenciación e identificación del gen de la enzima endo-PG de la cepa de K. marxianus CDBBL-278.

6.4 Distancia filogenética entre la endo-PG de $K$. marxianus y otras endo-PG de levaduras y hongos. 34

6.5 Crecimiento de K. marxianus CDBBL-278 y actividad enzimática de la endoPG bajo diferentes condiciones de oxígeno disuelto. .35

6.5.1 Medio de cultivo 35

6.5.2 Inóculo. 35

6.5.3 Condiciones de crecimiento .36

6.5.4 Determinación de crecimiento 36

6.5.5 Determinación de actividad enzimática mediante la cuantificación de azúcares reductores por el método de Nelson-Somogyi. 37

6.6 Expresión del gen bajo condiciones aerobias y anaerobias. .38

6.6.1 Obtención de cDNA .38

6.6.1.1 Obtención del paquete celular .38

6.6.1.2 Extracción de RNA. 39

6.6.1.3 Tratamiento con DNAsa a las muestras de RNA extraído .41

6.6.1.4 Transcripción inversa .41

6.6.2 Diseño de cebadores y sondas de hidrólisis para el PCR cuantitativo.

6.6.3 Ensayos de validación del método de PCR cuantitativo .45 
6.6.4 Cuantificación de la expresión del gen de la endo-PG en las diferentes condiciones de crecimiento.

7. RESULTADOS Y DISCUSIÓN

7.1 Extracción e identificación del gen de la enzima endo-PG en la cepa $K$. marxianus CDBBL-278.

7.2 Distancia filogenética de la endo-PG de K. marxianus CDBBL-278 con otras endo-PG de levaduras y hongos

7.3 Crecimiento y actividad enzimática bajo diferentes condiciones de oxígeno disuelto .58

7.4 Montaje de la técnica de extracción de RNA 63

7.4.1 Extracción de RNA en condiciones aerobias y anaerobias de crecimiento. 65

7.5 Tratamiento con DNAsa a las muestras de RNA......................69

7.6 Diseño de cebadores para el PCR cuantitativo. .70

7.6.1 Verificación del diseño de los cebadores y estandarización de las temperaturas de hibridación para el PCR tiempo real. .71

7.6.2 Verificación de la especificidad y amplificación por PCR tiempo real de las sondas. .75 7.7 Determinación de la eficiencia de amplificación de los genes EPG, $18 S$ y ACT1 con los cebadores diseñados. 78

7.8 Cuantificación del gen EPG durante el crecimiento de $K$. marxianus en condiciones de oxígeno controladas.

8. CONCLUSIONES. .87

9. PERSPECTIVAS .88 
10. BIBLIOGRAFÍA.

11. ANEXOS 96

12. PUBLICACIÓN CIENTÍFICA 104

\section{ÍNDICE DE FIGURAS}

Figura 1. Diagrama de acción de las enzimas pécticas: PMGL (pectinmetilgalacturonliasa), PGL (pectingalacturonliasa), PMG (pectinmetilgalacturonasa), PG (Poligalacturonasa), PE (Pectin esterasa)................17

Figura 2. Fundamento de la técnica para la cuantificación por PCR tiempo real

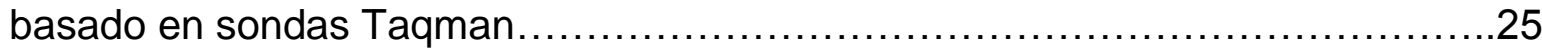

Figura 3. Electroforesis en gel de agarosa con los productos de la purificación del gen EPG obtenidos con el kit Montage PCR (Millipore). 48

Fig. 4 Alineamiento de la secuencia deducida de aminoácidos de la endo-PG de $K$. marxianus CDBBL-278 (KU240011) con la proteína EPG1 (cepa BKMY-719, No de acceso CAA03900.1) y proteína EPG1-2 (cepa CECT 1043 No. de acceso

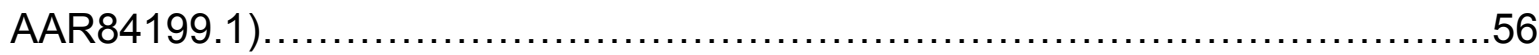

Figura 5. Árbol de máxima verosimilitud para el análisis filogenético de secuencia de aminoácidos 58

Figura 6. Crecimiento de biomasa y actividad endo-PG obtenidos en condiciones aerobias de crecimiento 59

Figura 7. Crecimiento de biomasa y actividad endo-PG obtenidos en condiciones anaerobias de crecimiento 60

Figura 8. Ajuste del crecimiento de K. marxianus al modelo logístico bajo diferentes condiciones de oxígeno disuelto 
Figura 9. Electroforesis en gel de agarosa al 1\% de los productos de extracción de RNA 63

Figura 10. Electroforesis de RNA total obtenido a partir del crecimiento de $K$. marxianus CDBBL-278 en condiciones aerobias y anaerobias 67

Figura 11. Electroforesis del producto de PCR obtenido a partir de RNA extraído de la levadura en crecimiento anaerobio después del tratamiento con DNAsa.....70

Figura 12. Electroforesis del producto de PCR con gradiente de temperatura de 52

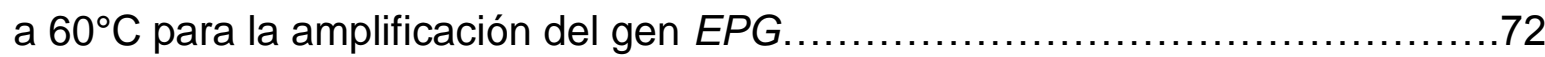

Figura 13. Electroforesis del producto de PCR con gradiente de temperatura de 53 a $63^{\circ} \mathrm{C}$ para la amplificación del gen $18 \mathrm{~S}$ .74

Figura 14. Electroforesis del producto de PCR con gradiente de temperatura de 53 a $57.2^{\circ} \mathrm{C}$ para la amplificación del gen $A C T 1$ .75

Figura 15. Curvas de amplificación por PCR tiempo real de los genes 185 y EPG para verificación de especificidad de los cebadores y sondas diseñados. . .76 Figura 16. Curvas de amplificación por PCR tiempo real del gene ACT1 para verificación de especificidad de los cebadores y sondas diseñados

Figura 17. Curvas de amplificación por PCR tiempo real y resultados de la eficiencia de amplificación para el gen ACT1 .79

Figura 18. Curvas de amplificación por PCR tiempo real y resultados de la eficiencia de amplificación obtenidos para el gen EPG. .80

Figura 19. Curvas de amplificación por PCR tiempo real y resultados de la eficiencia de amplificación obtenidos para el gen $18 S$ 81

Figura 20. Curvas de amplificación por PCR tiempo real para la cuantificación de la expresión del gen de la endo-PG en condiciones anaerobias de crecimiento...82

Figura 21. Curvas de amplificación por PCR tiempo real para la cuantificación de la expresión del gen de la endo-PG en condiciones aerobias de crecimiento....82 
Figura 22. Valores de Ct obtenidos bajo condiciones aerobias y anaerobias de crecimiento para $K$. marxianus..................................................... 84

Figura 23. Valores de $\mathrm{Ct}$ obtenidos para el gen blanco EPG y los genes normalizadores $18 S$ y $A C T 1$ bajo condiciones aerobias (A) y anaerobias (AN) de crecimiento. .85

\section{ÍNDICE DE TABLAS}

Tabla 1. Características de los cebadores diseñados para la amplificación de los genes EPG, $18 S$ y $A C T 1$ por medio de PCR tiempo real

Tabla 2. Comparación mediante BLAST de las secuencias de nucleótidos con alineamientos significativos con el gen de K. marxianus CDBBL-278. .50

Tabla 3. Comparación de la secuencia de aminoácidos para la endo-PG de $K$. marxianus CDBBL-278. 53-54

Tabla 4 Cuantificación de RNA con los diferentes métodos de extracción. 64

Tabla 5. Concentración y pureza del RNA extraído a partir del crecimiento aerobio 68

Tabla 6. Concentración y pureza del RNA extraído a partir del crecimiento anaerobio. .68 


\section{RESUMEN}

En el presente trabajo se realizó la extracción de DNA de la levadura $K$. marxianus CDBBL-278 con la finalidad de caracterizar el gen que codifica para la enzima endopoligalacturonasa (endo-PG). Se logró obtener la secuencia de 945 nucleótidos (315 aminoácidos) que codifican para la enzima endo-PG de esta levadura. Se realizó un análisis comparativo de la secuencia obtenida con otras dos endo-PG reportadas para $K$. marxianus y se encontró que la endo-PG de la levadura K. marxianus CDBBL-278 presenta un 99\% de identidad con el alelo EPG1-2 y un $98 \%$ de identidad con el gen EPG1, manteniendo una mayor similitud con el primero, además presenta un $99 \%$ de identidad con otras secuencias del cromosoma 1 de $K$. marxianus reportadas en la base de datos del National Center of Biotechnology Information (NCBI). A partir de la secuencia de aminoácidos, se llevó a cabo una reconstrucción filogenética mostrando que la endo-PG de $K$. marxianus CDBBL-278 representa un linaje evolutivo separado de las endo-PG de otras levaduras pertenecientes a esta misma especie. Finalmente se cuantificó el nivel de expresión del gen de la endo-PG (EPG) de esta levadura bajo condiciones aerobias y anaerobias de crecimiento y se relacionó con la actividad enzimática. Los resultados señalan que el aumento de la producción de endo-PG bajo condiciones de cultivo anaerobio es una consecuencia de la regulación del gen EPG por la saturación de oxígeno disuelto en el medio de crecimiento. 


\section{Abstract}

Kluyveromyces marxianus is a good producer of endopolygalacturonase (EC. 3.2.1.15); it has been reported that its production is repressed under high dissolved oxygen tension. The expression of the endopolygalacturonase gene (EPG) from this yeast was compared under both aerobic and anaerobic conditions and was related to the enzyme activity. Specific enzyme production under anaerobic conditions $\left(0.233 \mathrm{uPG} \mathrm{mg}^{-1}\right)$ was five times higher than that obtained under aerobic conditions $\left(0.048 \mathrm{uPG} \mathrm{mg}{ }^{-1}\right)$, demonstrating that anaerobic growth promotes the synthesis of endo-PG; relative quantification of EPG gene expression was 21.19 times higher in anaerobic culture, suggesting that production of endo-PG under anaerobic culture conditions is a consequence of the regulation of the EPG gene by dissolved oxygen saturation in the growth medium. Results point out that the higher production of endo-PG under anaerobic culture conditions is a consequence of the regulation of EPG gene by dissolved oxygen saturation in the growth medium. 


\section{INTRODUCCIÓN}

La cepa Kluyveromyces marxianus CDBBL-278 es una extraordinaria productora de endo-PG (EC. 3.2.1.15) (Espinoza et al. 1992). Esta enzima pectinolítica ha demostrado tener utilidad en el procesamiento de vegetales, particularmente en la clarificación de jugo de manzana (Gómez Ruiz et al. 1988). En otras cepas de K. marxianus se ha secuenciado el gen de esta enzima, habiéndose encontrado dos alelos del mismo: EPG1 (Siekstele et al. 1999) y EPG1-2 (Sieiro et al. 2009). El gen de la cepa CDBBL-278 no ha sido secuenciado, pero se ha reportado que su actividad enzimática está regulada por el oxígeno disuelto en el medio de cultivo (Cruz-Guerrero et al. 1999).

En este trabajo se aisló y secuenció el gen de la endo-PG de $K$. marxianus CDBBL-278, posteriormente se obtuvo la estructura primaria, se realizó también un estudio taxonómico basado en la secuencia de la enzima para obtener la relación filogenética de ésta con otras enzimas poligalacturonasas. Se investigó mediante PCR tiempo real transcripción inversa (RT-q-PCR) la expresión del gen de la enzima endo-PG bajo dos condiciones de oxígeno disuelto, con la finalidad de demostrar si el nivel de expresión del gen se ve afectado por la concentración de oxígeno disuelto en el medio y su repercusión en la actividad de la enzima. 


\section{ANTECEDENTES}

\subsection{Kluyveromyces marxianus}

Cepas pertenecientes a la especie de levadura Kluyveromyces marxianus han sido aisladas a partir de una gran variedad de hábitats, lo que ha permitido demostrar una elevada diversidad metabólica y un alto grado de polimorfismo intraespecífico. Se han encontrado e investigado varias aplicaciones biotecnológicas con esta levadura: producción de enzimas ( $\beta$-galactosidasa, $\beta$ glucosidasa, inulinasa y poligalacturonasa), obtención de proteína unicelular, compuestos aromáticos y etanol, reducción de contenido de lactosa en productos alimenticios, producción de bioingredientes a partir de suero de queso; en biorremediación, como agente anticolesterolémico; y como huésped para la producción de proteínas heterólogas (Graciano et al. 2008).

K. marxianus ha sufrido varios cambios en su clasificación taxonómica, lo cual ha conducido al uso de varios nombres para esta especie y levaduras estrechamente relacionadas. Esto ha creado confusión, en muchos casos, entre aquellos que buscan las aplicaciones biotecnológicas de esta levadura tan versátil y no son expertos en taxonomía de levaduras.

La especie $K$. marxianus incluye ahora las levaduras antiguamente conocidas como Saccharomyces marxianus (nombrada por Hansen en 1888) y Saccharomyces fragilis (nombrada por Jörgensen en 1909). En 1970 estas dos especies fueron clasificadas dentro del género Kluyveromyces, siendo respectivamente $K$. marxianus y $K$. fragilis. Otras especies ahora consideradas 
como sinónimos de $K$. marxianus son $K$. bulgaricus, $K$. cicerisporus y $K$. wikenii (Graciano et al. 2008).

El hecho de que K. marxianus haya sido representada por cinco nomenclaturas de especies diferentes refleja la heterogeneidad fenética de las especies, y explica por qué es difícil distinguirlas de otros taxones relacionados, especialmente de $K$. lactis. Sin embargo K. marxianus es la única especie de Kluyveromyces que asimila inulina, que no asimila o fermenta alfa-glucósidos y crece bien a $37^{\circ} \mathrm{C}$ (Kurtzman y Fell 2000).

\section{2 K. marxianus CDBBL-278}

La cepa K. marxianus CDBBL-278, (Colección del Departamento de Biotecnología y Bioingeniería) obtenida de la colección de cultivos microbianos del Centro de Investigación y de Estudios Avanzados del Instituto Politécnico Nacional (CINVESTAV-IPN), ha sido utilizada previamente en nuestro grupo de trabajo, y se ha observado que es una cepa capaz de producir simultáneamente proteína unicelular y endo-poligalacturonasa en un medio con lactosa, sugiriendo la posibilidad de utilizar el suero de leche para la producción de estos dos productos de interés comercial (García-Garibay et al. 1987).

Así mismo, la enzima endo-PG ha sido utilizada para la clarificación de jugo de manzana, comparando su eficiencia de clarificación con la de una pectinasa 
comercial, determinándose que no hay diferencia entre ambas enzimas (GómezRuiz et al. 1988).

En otro estudio se observó que esta misma cepa fue capaz de producir simultáneamente las enzimas lactasa y pectinasa, además de lactasa e inulinasa bajo condiciones específicas de crecimiento (Espinoza et al. 1992).

La misma levadura fue estudiada por Cruz-Guerrero et al. (1995), observando que es una levadura hiperproductora de inulinasa comparada con otras dos levaduras reportadas como productoras de esta enzima.

\subsection{Pectinas y enzimas pectinolíticas}

Las pectinas son heteropolisacáridos constituyentes de los componentes estructurales mayoritarios de la pared celular primaria y lámina media de plantas superiores.

Consisten de un esqueleto que contiene mayoritariamente una gran proporción de subunidades de ácido poligalacturónico unidas por enlaces glucosídicos $\alpha-1,4$, parcialmente metil esterificado. Este compuesto es conocido como pectina, mientras que el compuesto no metilado, recibe el nombre de ácido péctico o ácido poligalacturónico (Blanco et al. 1999).

Las enzimas que hidrolizan sustancias pécticas son conocidas como enzimas pécticas, pectinasas o enzimas pectinolíticas (Figura 1) y pertenecen a la familia de polisacaridasas que contribuyen a la degradación de pectina de plantas. 
Las pectinasas se encuentran ampliamente distribuidas en plantas superiores donde están involucradas en la modificación de sustratos pécticos durante el proceso de maduración natural de algunas frutas. Muchas pectinasas también son producidas por microorganismos, algunas de las cuales se ha reportado que están involucradas en la proliferación de microrganismos fitopatógenos (AlimardaniTheuil et al. 2011).

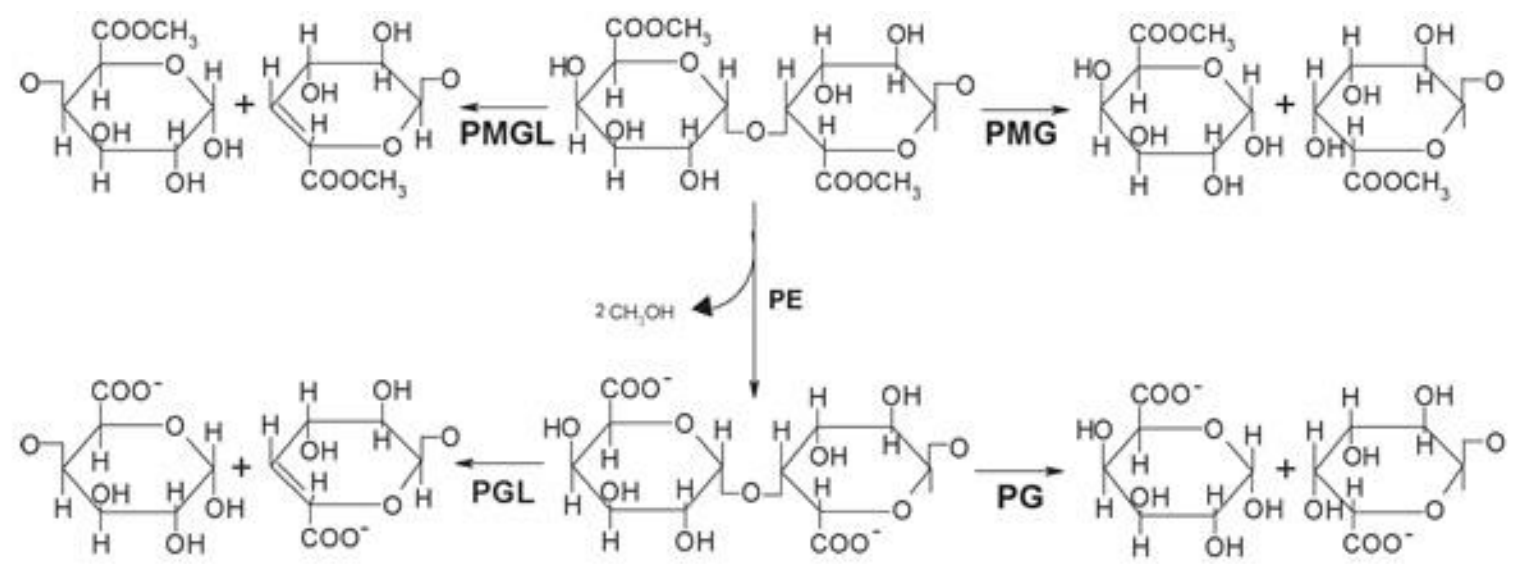

Figura 1. Diagrama de acción de las enzimas pécticas: PMGL (pectinmetilgalacturonliasa), PGL (pectin-galacturonliasa), PMG (pectin metilgalacturonasa), PG (Poligalacturonasa), PE (Pectin esterasa)

De acuerdo al patrón de acción sobre la pectina o el ácido poligalacturónico, las enzimas pectinasas se clasifican en dos grandes grupos: pectin-esteras (des esterifican la pectina removiendo el residuo metodillo) o des polimerasas (las cuales rompen la cadena principal). Las enzimas des polimerasas se dividen en poligalacturonasas (hidrolíticas) y liasas (rompen uniones glicosídicas por $\beta$ - 
eliminación). A su vez estas dos últimas se clasifican con base en su preferencia de hidrólisis contra pectina, ácido péctico, o ácido poligalacturónico, siendo su patrón de hidrólisis al azar (endo) o terminal (exo) (Blanco et al. 1999).

Las pectinasas fueron de las primeras enzimas utilizadas en forma casera. Su aplicación comercial fue observada en 1930 para la preparación de vinos y jugos de fruta. Actualmente las pectinasas son de las enzimas más utilizadas en la industria de frutas y textiles (Kashyap et al. 2001)

Las pectinasas ácidas son utilizadas en la industria productora de jugos de fruta y vino y éstas frecuentemente provienen de fuentes fúngicas, especialmente a partir de Aspergillus niger.

Las pectinasas alcalinas son utilizadas en la industria textil para el encurtido y el desengomado de cultivos de fibra, y para la producción de papel de buena calidad; también se usan en la fermentación de café y el té, las extracciones de aceite de diferentes vegetales, y el tratamiento de las aguas residuales. Estas enzimas provienen mayoritariamente de fuentes bacterianas como Bacillus spp (Kashyap et al. 2001).

\subsection{Endopoligalacturonasas (endo-PG) en levaduras}

Los primeros autores en describir la producción de endo-PG por levaduras fueron Luh y Phaff en 1951. En 1954, dichos autores publicaron un estudio de éstas enzimas, comparándolas con enzimas reportadas en hongos filamentosos (Luh y Phaff, 1954). 
Las pectinasas de levaduras son usualmente enzimas exocelulares con una masa molecular variable y de naturaleza glicoproteínica. En algunas levaduras se ha demostrado la presencia de varias isoenzimas, tal es el caso de Saccharomyces fragilis y K. marxianus (Blanco et al. 1999). Las enzimas pécticas de levaduras son exclusivamente endo-PG, es decir, son enzimas que degradan al azar la cadena principal, en los puntos no metilados, vía hidrólisis del enlace $\alpha-1,4$ glucosídico.

Se ha reportado que la producción de pectinasa es una capacidad constitutiva en las levaduras ya que no se requieren la pectina, el ácido poligalacturónico, o el ácido galacturónico para inducir la síntesis de la enzima (Blanco et al. 1999) Sin embargo, la capacidad pectinolítica de algunas especies de levaduras como Cryptococcus albidus (Federici, 1985), Kluyveromyces fragilis (García Garibay et al. 1987) y Geotrichum lactis (Pardo et al. 1991) se han descrito como inducibles y la poligalacturonasa de S. fragilis como parcialmente constitutiva (Lim y Suzuki, 1980). Wimborne y Rickard (1978) postularon que la enzima endo-PG de K. fragilis se producía de forma parcialmente constitutiva después de observar que la adición de pectina al medio de cultivo aumentó al doble la producción de pectinasa. García Garibay et al. (1987) obtuvieron actividad poligalacturonasa en una cepa de $K$. fragilis al adicionar pectina a un medio de cultivo con lactosa como fuente de carbono y en condiciones aerobias.

Otra característica común para la mayoría de las enzimas pécticas es la represión catabólica; sin embargo, de acuerdo a Schwan y Rose (1996), la poligalacturonasa de $K$. marxianus es muy inusual ya que su producción es constitutiva y no se 
reprime por carbohidratos; dichos autores obtuvieron altos rendimientos en la producción de la enzima a concentraciones de glucosa y fructosa mayores al $10 \%$ (peso/volumen) bajo condiciones anaerobias de autoinducción. Cruz Guerrero (1995), realizó un estudio del efecto represivo/inductor de la glucosa en la producción de la enzima endo-PG y encontró que a concentraciones de $0.2-2 \%$ de glucosa tanto en condiciones aerobias como anaerobias hay un incremento en la actividad de la enzima, siendo mayor en condiciones anaerobias.

La actividad poligalacturonasa en las levaduras también está relacionada con la cantidad de oxígeno disuelto en el medio. Varias especies, como K. marxianus, $K$. fragilis (Blanco et al. 1999) y K. lactis (Murad y Foda, 1992) presentan capacidad pectinolítica cuando crecen sin agitación y bajo condiciones anaerobias y no presentan actividad cuando hay niveles altos de aireación. Cruz Guerrero et al. (1999), demostraron que la producción de la enzima endo-PG es constitutiva bajo condiciones anaerobias con una concentración umbral de oxígeno disuelto (OD) de $3.3 \mathrm{mg} / \mathrm{ml}(60 \% \mathrm{OD})$, observaron también que a concentraciones de $20 \%$ y $40 \%$ se produce la enzima, sugiriendo una condición umbral entre 40 y $60 \%$ para reprimir la producción de la endo-PG. Observaron también que la adición de pectina al medio incrementó la producción de la endo-PG bajo las condiciones de oxígeno disuelto en estudio (20,40 y $60 \%)$ lo cual indica que la represión de la síntesis de la endo-PG se revierte por la adición de pectina.

En la gran mayoría de los estudios publicados de $K$. marxianus, los objetivos no están dirigidos a explicar su bioquímica, metabolismo o fisiología. La mayoría de 
los trabajos se han enfocado a explorar las aplicaciones biotecnológicas de éste organismo, sin investigar lo que ocurre a nivel intracelular (Graciano et al. 2008). En otros casos, K. marxianus simplemente es utilizada como una fuente de compuestos específicos, mayoritariamente enzimas. En términos de estudios bioquímicos de enzimas que tienen interés industrial, $K$. marxianus ha sido utilizada como una fuente de inulinasas, $\beta$-galactosidasa, $\beta$-glucosidasa y endo$P G$.

\subsection{Genes de pectinasas en K. marxianus}

En los últimos años, varios estudios se han enfocado al análisis estructural y la regulación de la expresión de genes que codifican pectinasas. Para el caso de las levaduras los genes que codifican para endo-PG reportados hasta la fecha son: EPG1 (Siekstele et al. 1999) y alelo EPG1-2 (Sieiro et al. 2009) para K. marxianus y el gen PGU1 (PGL1) para S. cerevisiae (Blanco et al. 1998). Las características del gen EPG1 (identificado en la cepa de K. marxianus BKMY-719 aislada de uvas), posee un ORF (marco abierto de lectura) de 1083 pb (pares de bases) que codifican para un polipéptido de 361 aminoácidos. La secuencia de aminoácidos y el tamaño del polipéptido son similares a lo reportado para PG de hongos. La secuencia del gen contiene dos potenciales sitios de $\mathrm{N}$-glicosilación y una secuencia señal. Posee una masa molecular teórica de 34,702 Da y un pl de 6.05. Esta enzima posee cuatro isoenzimas con masas moleculares de 45, 42, 39 y 36 $\mathrm{kDa}$ (la diferencia en masa se debe a modificaciones post-traduccionales (Alimardan-Tehuili et al. 2011). 
Las características del gen EPG1-2 (identificado en la cepa de $K$. marxianus CECT 1043) son las siguientes: consiste en 1086 pb los cuales codifican para una proteína de 362 aminoácidos. Comparado con el gen EPG1, el alelo EPG1-2 contiene una valina adicional en la posición 122. Los genes EPG1 y EPG1-2 difieren en otros 12 aminoácidos, diferencia que no afecta a las regiones conservadas de la PG. El polipéptido posee 2 puntos hipotéticos de glicosilación situados en los aminoácidos $\mathrm{N}^{189}$ y $\mathrm{N}^{293}$ (asparagina-189 y asparagina 293) (Sieiro et al. 2009).

\subsection{Estudio de la expresión de genes}

El análisis cuantitativo de los ácidos nucleicos ha tenido un rol importante en el campo de la investigación biológica. La medición de la expresión de genes (mRNA, RNA mensajero) se ha utilizado extensamente para monitorear respuestas biológicas a varios estímulos. Se han descrito muchos métodos para el análisis cuantitativo de secuencias de ácidos nucleicos (tanto para DNA como RNA). La técnica de PCR ha demostrado ser una herramienta poderosa para el análisis cuantitativo de los ácidos nucleicos (Heid et al. 1996). Comparado con los métodos basados en cultivo, el PCR es más rápido, más sensible y más específico.

EI PCR en tiempo real ofrece la posibilidad de cuantificar poblaciones microbianas a través de la medición del número de genes. Combinado con la transcripción reversa $(\mathrm{RT})$ el PCR cuantitativo (qPCR) puede también estimar la cantidad de 
transcritos producidos bajo un estímulo particular. Actualmente, el PCR cuantitativo (qPCR) y el PCR cuantitativo con retrotranscripción (RT-q-PCR) se han convertido en los métodos de elección para cuantificar genes y expresión de genes respectivamente (Postollec et al. 2011).

La reacción en cadena de la polimerasa con retrotranscripción o transcripción inversa (RT-PCR) es un método para amplificar enzimáticamente (indirectamente) e in vitro secuencias definidas de RNA mensajero (RNAm). El RT-PCR puede ser usado para comparar niveles de RNAm en diferentes poblaciones, caracterizar patrones de expresión de RNAm y discriminar entre RNAm relacionados (TaiLeong et al. 2007).

El RT-PCR puede llevarse a cabo de dos formas: PCR punto final y el PCR tiempo real. EI PCR tiempo real consiste en una sucesión de ciclos de amplificación en la cual el molde de ácido nucleico se desnaturaliza, se alinea con cebadores específicos y se elonga para generar una cadena complementaria usando una DNA polimerasa termoestable. Esto resulta en un incremento exponencial del número de ampliaciones (productos de amplificación) que, en contraste con el PCR punto final, puede ser monitoreado en cada ciclo (en tiempo real) utilizando un reportero fluorescente. El incremento en la fluorescencia es graficado contra el número de ciclo para generar una curva de amplificación, a partir de la cual, un valor de ciclo de amplificación $\mathrm{Cq}$ (frecuentemente descrito como Ct o ciclo umbral), puede ser cuantificado (Postollec et al. 2011). 
Varias técnicas de detección están disponibles actualmente y su elección depende de la aplicación. La química Taqman aprovecha la actividad exonucleasa 5'- 3'de la Taq DNA polimerasa para degradar una sonda durante la PCR (Figura 2). La sonda de degradación contiene un colorante delator fluorescente en el extremo 5' y un colorante inhibidor en el extremo $3^{\prime}$. Al estar bloqueado el extremo $3^{\prime}$ la sonda no puede extenderse como un primer. Durante la PCR en presencia de una secuencia diana la sonda se hibrida específicamente. Cuando la sonda está intacta, la proximidad del colorante delator al colorante inhibidor produce la supresión de la fluorescencia delatora. Durante la reacción, la actividad exonucleasa 5'- 3'de la Taq DNA polimerasa degrada la sonda entre los colorantes delator e inhibidor solamente si la sonda se hibrida con la secuencia diana. De esta manera la fluorescencia aumenta a medida que progresa la amplificación. La acumulación del producto de PCR se detecta monitoreando el incremento de la fluorescencia del colorante delator (Querci et al. 2007). 


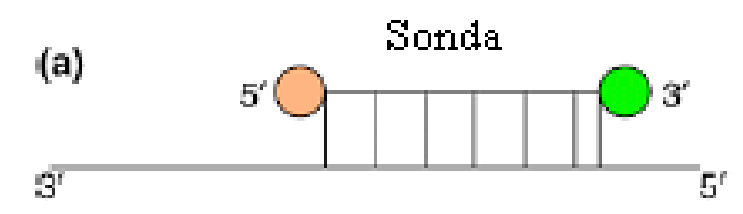

Secuencia blanco

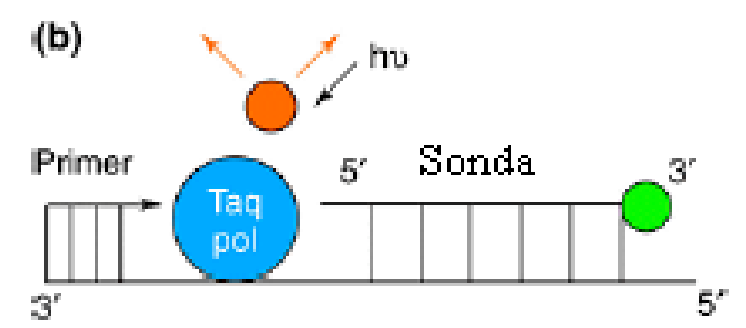

Secuencia blanco

fotocrom oreportero $\bigcirc$
fotocrom o quencher $\bigcirc$
quencher

(a)Cuando la sonda, hibridada o no, cstá intacta el fotocromo reporter no emite por acción del quencher.

(b) La sonda es hidrolizada durante la reacción de PCR y el reporter fluoresce.

Figura 2. Fundamento de la técnica para la cuantificación por PCR tiempo real basado en sondas Taqman

Hay dos categorías comunes de cuantificación usando el PCR tiempo real, la cuantificación absoluta y la cuantificación relativa.

La cuantificación relativa comúnmente se lleva a cabo por normalización de los niveles de expresión del gen de interés con genes housekeeping (constitutivos). La normalización corrige las diferencias en las concentraciones de DNA 
resultantes de variaciones durante la preparación de la muestra para permitir la comparación cruzada entre muestras. Cuando se normaliza un gen de referencia, es muy importante que el gen de referencia sea experimentalmente validado para asegurar que la medición de éste sea confiable. Los datos normalizados se reportan como el cociente de la concentración de RNAm del gen de interés y la concentración del gen de referencia (Brookman-Amissah et al. 2015).

Livak y Schmittgen (2001) reportaron el primer método para la conversión de valores de Ct (valores de ciclo de cuantificación) en cantidades relativas normalizadas (NRQ). Este modelo simple asume el $100 \%$ de eficiencia de amplificación (reflejado como un 2 para la base de la función exponencial E) utilizando solo un gen de referencia para la normalización $\left(N R Q=2^{\Delta \Delta c t}\right)$.

Pfaffl (2001) modificó el modelo anterior, ajustando las diferencias en la eficiencia de amplificación entre el gen de interés (goi) y el gen de referencia (ref).

$$
N R Q=\frac{E_{g o i}^{\Delta C t, g o i}}{E_{r e f}^{\Delta C t, r e f}}
$$

$\mathrm{NRQ}=$ Cantidad relativa normalizada

$E_{\text {goi }}=$ Eficiencia de amplificación del gen blanco

$\Delta \mathrm{Ct}_{\text {goi }}=$ Diferencia de valores $\mathrm{Ct}$ del gen blanco en las condiciones bajo estudio $\mathrm{E}_{\mathrm{ref}}=$ Eficiencia de amplificación del gen de referencia

$\Delta \mathrm{Ct}_{\text {ref }}=$ Diferencia de valores $\mathrm{Ct}$ del gen de referencia en las condiciones bajo estudio 
Este modelo constituye una mejora, pero no cumple con el uso de múltiples genes de referencia, lo cual es un requisito para una adecuada medición de las diferencias de expresión (Vandesompele et al, 2002).

Hellemans et al. (2007) ampliaron este último modelo tomando en cuenta la estabilidad de expresión de múltiples genes de referencia para mejorar la normalización.

La cuantificación relativa podría dar sólo una comparación de la proporción del gen de interés y no el número de copias en una concentración definida de poblaciones de RNAm, por lo que existe también una cuantificación absoluta, la cual depende de una curva estándar construida a partir de concentraciones conocidas de un molde estándar correspondientes a los niveles de los datos del PCR. Frecuentemente los estándares son derivados a partir de plásmidos purificados de DNA de doble cadena, RNA transcrito in vitro o DNA de cadena sencilla sintetizado in vitro. La cantidad es cuantificada espectrofotométricamente a $260 \mathrm{~nm}$ o con un marcador de DNA fluorescente y convertido a número de copias usando el peso molecular de RNA o de la secuencia de DNA (Tai-Leong et al. 2007). 


\section{HIPÓTESIS}

El oxígeno disuelto en el medio de cultivo de crecimiento tiene un efecto en la regulación de la expresión del gen de la endopoligalacturonasa de K. marxianus.

\section{OBJETIVO GENERAL}

Identificar y caracterizar la endo-PG de Kluyveromyces marxianus CDBBL-278 así como analizar el efecto de las condiciones de crecimiento en la actividad de la enzima y en la expresión del gen.

\section{OBJETIVOS ESPECÍFICOS}

Obtener la relación filogenética entre la endo-PG de K. marxianus CDBBL-278 y las endo-PG de otras levaduras y hongos

Evaluar el efecto de las condiciones de oxígeno en el crecimiento y actividad enzimática de Kluyveromyces marxianus CDBBL-278 


\section{METODOLOGÍA}

\subsection{ESTRATEGIA EXPERIMENTAL}

6.1.1 Aislamiento e identificación del gen de la endo-PG en la cepa $K$. marxianus CDBBL-278

Extracción del ADN de la levadura

Secuenciación del fragmento del gen amplificado
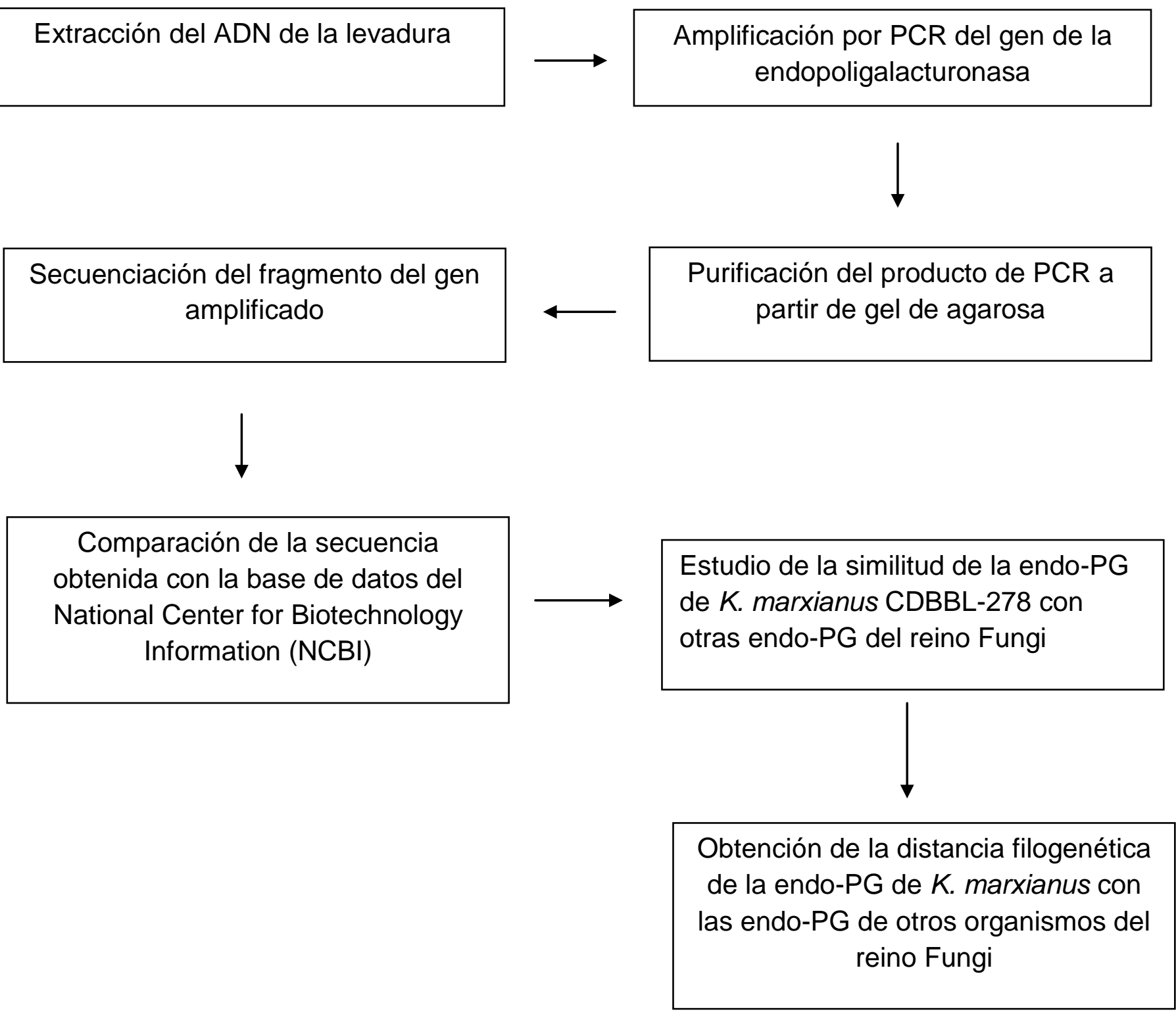
6.1.2. Cuantificación del gen de la endo-PG mediante PCR cuantitativo bajo diferentes condiciones de crecimiento (oxígeno disuelto)

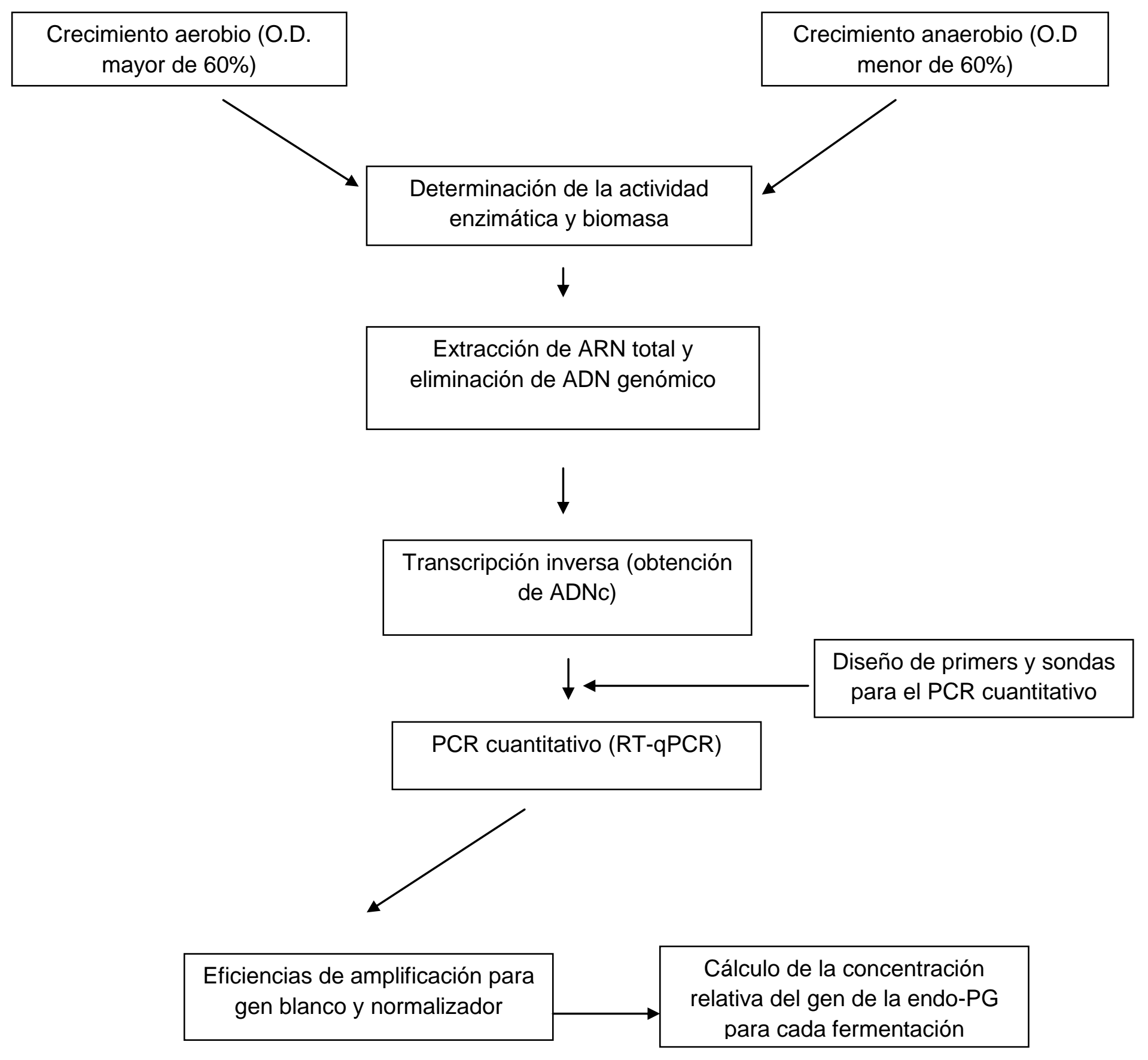




\subsection{Microorganismo}

Se utilizó la levadura Kluyveromyces marxianus CDBBL-278 obtenida de la colección de cultivos del CINVESTAV (Centro de Investigaciones y Estudios Avanzados) del Instituto Politécnico Nacional, la cual se mantuvo en tubos inclinados con agar papa dextrosa (Difco, Sparks MD, USA).

6.3 Identificación del gen que codifica para la endo-PG de la cepa de K. marxianus CDBBL-278

\subsubsection{Preparación del paquete celular}

Se inoculó la levadura en caldo YM (0.1\% extracto de levadura, $0.5 \%$ peptona, $2 \%$ glucosa; Bioxon, México). Se incubó con agitación orbital a 200 rpm durante 24 h a $30{ }^{\circ} \mathrm{C}$. Al final de la incubación se centrifugaron las células a $3020 \times g$ durante 15 min. Las células se lavaron dos veces con agua destilada estéril, eliminando el sobrenadante después de cada lavado. Se transfirió el paquete celular a tubos Eppendorf y se resuspendió en $1 \mathrm{ml}$ de agua estéril. Los tubos se congelaron para posterior extracción de DNA.

\subsubsection{Extracción de DNA}

El paquete celular se descongeló y se centrifugó en microcentrífuga a $12000 \times g$ durante $10 \mathrm{~min}$. Se eliminó el sobrenadante y se añadieron a las células $500 \mu \mathrm{l}$ de 
buffer de extracción y el equivalente a $200 \mu$ l de perlas de vidrio lavadas en ácido (425-600 $\mu \mathrm{m}$; Sigma). La suspensión se agitó en vortex a velocidad máxima durante 3 min. Se incubó en baño de agua a $65^{\circ} \mathrm{C}$ durante $1 \mathrm{~h}$. Después de la incubación la suspensión se agitó a máxima velocidad en vortex durante 3 min y se centrifugó a $12000 \times$ g durante 10 min. El sobrenadante se transfirió a un tubo Eppendorf nuevo y estéril, se le añadieron $700 \mu \mathrm{l}$ de una mezcla de fenol/cloroformo/alcohol isoamílico (24:24:1, Sigma) se agitó suavemente inclinando el tubo y se centrifugó a 12000 x g durante 10 min. El sobrenadante se transfirió a un tubo limpio y estéril y se añadió nuevamente la mezcla de fenol/cloroformo/alcohol isoamílico, repitiendo también la centrifugación. Se transfirió el sobrenadante a un tubo Eppendorf nuevo y estéril y se añadieron 500 $\mu \mathrm{l}$ de cloroformo, se agitó suavemente y se centrifugó a 12000 × $g$ durante 5 min. Se transfirió el sobrenadante a un tubo nuevo y estéril y se añadieron $324 \mu \mathrm{l}$ de isopropanol frío (Sigma). El sobrenadante se mantuvo a $4{ }^{\circ} \mathrm{C}$ durante 5 min para precipitar el DNA. Para aquellos casos en los que no se observó DNA precipitado, se añadieron $4 \mu \mathrm{l}$ de acetato de amonio $3 \mathrm{M}$ y se mantuvo a $4{ }^{\circ} \mathrm{C}$ durante $1 \mathrm{~h}$. Se centrifugó el DNA a 12000 x g durante 5 min. Se descartó el sobrenadante y el DNA precipitado se lavó con $1 \mathrm{ml}$ de etanol frio añadiéndolo lentamente por las paredes del tubo. Se centrifugó a 12000 × g durante 5 min descartando el etanol. La pastilla de DNA se diluyó en agua desionizada estéril y se incubó en baño de agua a $55{ }^{\circ} \mathrm{C}$ durante $15 \mathrm{~min}$. El DNA se guardó en congelación para su uso posterior. 


\subsubsection{Amplificación del gen que codifica para endo-PG}

Para las reacciones de amplificación (PCR) se utilizaron 10-25 ng de DNA genómico como molde. Se emplearon los cebadores reportados por Sieiro et al. (2009): cebador de ida (forward, fw) es KM1 (5'ATGTTATTCAGCAACACCTTATTGAT-3') y de regreso (reverse, rw) KM1REV (5'TTAACAGAAGGCTCCGCTACCAG-3'). La reacción de PCR se llevó a cabo en 50 $\mu \mathrm{l}$ de volumen final con las siguientes concentraciones de reactivos: Buffer PCR 1X, $2.5 \mathrm{mM}$ de $\mathrm{MgCl}_{2}, 200 \mu \mathrm{M}$ de dNTPmix, $0.15 \mu \mathrm{M}$ de cada cebador, $1 \mathrm{UI}$ de Platinum Taq DNA polimerasa. Las condiciones de reacción del PCR fueron: desnaturalización inicial de $94{ }^{\circ} \mathrm{C}$ durante 2 min, 30 ciclos de $94{ }^{\circ} \mathrm{C}$ durante 1 min, $56{ }^{\circ} \mathrm{C}$ durante $1 \mathrm{~min}, 72{ }^{\circ} \mathrm{C}$ durante 1 min y una extensión final de $72{ }^{\circ} \mathrm{C}$ por 5 min. Los productos de amplificación se analizaron realizando una electroforesis en gel de agarosa al $2 \%$ teñidos con rojo texas $(0.5 \mu \mathrm{g} / \mathrm{ml})$ visualizándolos bajo luz UV en un fotodocumentador MiniLumi DNR, (Bio-Imaging Systems Ltd, Jerusalem, Israel)

6.3.4 Secuenciación e identificación del gen de la enzima endo-PG de la cepa de K. marxianus CDBBL-278

Los fragmentos de DNA amplificados se purificaron con el kit Wizard SV gel and PCR clean up system (Promega Madison WI, USA), siguiendo las especificaciones del proveedor, y se enviaron a secuenciar al Laboratorio Divisional de Biología Molecular de la UAM Iztapalapa en un equipo ABIPRISM 3100 AVANT. Las secuencias obtenidas se compararon en la base de datos del National Center for 
Biotechnology Information (http://ncbi.nih.gov), utilizando la herramienta BLAST (Basic Local Alignment Search Tool) para buscar las secuencias del gen relacionadas, con lo cual se obtuvo la identificación del mismo. La secuencia de nucleótidos de la región genómica que codifica para la endo-PG de la cepa Kluyveromyces marxianus CDBBL-278 se depositó en la base de datos del GenBank con el número de acceso KU240011.

6.4 Distancia filogenética entre la endo-PG de K.marxianus y otras endo-PG de levaduras y hongos

Para el análisis filogenético se alinearon mediante Clustal W (Larkin et al 2007) la secuencia de aminoácidos de 27 distintas endo-PG de levaduras y hongos con la secuencia proporcionada por el $\mathrm{NCBI}$ para la endo-PG de Kluyveromyces marxianus CDBBL-278 (No. de acceso ANB44747.1). Se utilizó el ProtTest (Darriba et al. 2011) con la finalidad de seleccionar el mejor ajuste por modelo de sustitución utilizando AIC (Akaike Information Criterion). Se seleccionó el modelo WAG+l+G+F (Matriz de sustitución WAF + parámetros I, G, F) Finalmente se utilizó el programa PhyML (algoritmo para estimar la Filogenia de Máxima Verosimilitud, Guindon y Gascuel, 2003) para inferir el árbol de máxima verosimilitud utilizando el modelo seleccionado por ProtTest. Se llevaron a cabo 100 ensayos de rutina utilizando PhyML. 
6.5 Crecimiento de Kluyveromyces marxianus CDBBL-278 y actividad enzimática dela endo-PG bajo diferentes condiciones de oxígeno disuelto

\subsubsection{Medio de cultivo}

Se preparó en agua destilada el medio de cultivo que a continuación se describe:

$0.1 \%$ de $\left(\mathrm{NH}_{4}\right)_{2} \mathrm{SO}_{4}, 0.05 \%$ de $\mathrm{KHPO}_{4}, 0.2 \%$ glucosa, $0.05 \%$ de $\mathrm{MgSO}_{4}, 0.2 \%$ extracto de levadura. Las sales utilizadas fueron J.T. Baker (N.J. USA) y los reactivos para cultivo microbiano Bioxon (México). Se ajustó el pH del medio a 5 con $\mathrm{NaOH}$ o $\mathrm{H}_{2} \mathrm{SO}_{4}$ según el caso. Se esterilizó a $121^{\circ} \mathrm{C}$ durante 15 min.

\section{5 .2 Inóculo}

Se prepararon $50 \mathrm{ml}$ de medio de cultivo de acuerdo a lo descrito en el apartado anterior en un matraz Erlenmeyer de $250 \mathrm{ml}$. Se inoculó el medio tomando con un asa bacteriológica las colonias de K. marxianus CDBBL-278 crecidas en una placa de agar papa dextrosa (PDA). Se incubó el cultivo a $30^{\circ} \mathrm{C}$ durante 16-18 horas con una agitación de 200 rpm. Para inocular este cultivo en el fermentador se ajustó la densidad óptica a 1.8 leyendo en espectrofotómetro (Shimadzu, UV1601, Kyoto, Japan) a una longitud de onda de $650 \mathrm{~nm}$. 


\subsubsection{Condiciones de crecimiento}

Para el estudio de la expresión del gen de la endo-PG en las diferentes condiciones de crecimiento se utilizó un fermentador Bioflo llc (New Brunswick) con $1 \mathrm{~L}$ del medio descrito en el apartado 2.1. El medio de cultivo se inoculó con $50 \mathrm{ml}$ del inóculo (5\%) de acuerdo a las condiciones antes descritas. Las condiciones de crecimiento se mantuvieron a $30{ }^{\circ} \mathrm{C}$ durante $9 \mathrm{~h}$ controlando la agitación manualmente para mantener la concentración de oxígeno disuelto mayor o igual a $60 \%$ (para el caso de la fermentación aerobia) con un flujo de aire constante de $2 \mathrm{~L} / \mathrm{min}$.

Las fermentaciones anaerobias se realizaron en el mismo fermentador con $1 \mathrm{~L}$ de medio de cultivo inoculado con el $5 \%$ de inóculo, ajustado a una absorbancia de 1.8. En esta fermentación no se administró aire y se mantuvo con una agitación de 50 rpm con la finalidad de homogenizar el medio.

Se tomaron muestras de $15 \mathrm{ml}$ en diferentes tiempos a lo largo de las fermentaciones para determinar la actividad enzimática por medio del método de Nelson Somogyi (Nelson 1944) y se recolectaron las células para proceder a la extracción de RNA.

\subsubsection{Determinación de crecimiento}

El crecimiento de la levadura se cuantificó por densidad óptica a 650 nm utilizando una curva patrón de peso seco, expresado en $\mathrm{mg} \mathrm{ml}^{-1}$. 
Los datos experimentales del crecimiento de la levadura se ajustaron al modelo logístico de Velhurst-Pearl (Ecuación 1) con la herramienta Solver de Excel de Microsoft office 2007.

$$
\mathrm{X}(\mathrm{t})=\frac{\mathrm{Xmax}}{1+\frac{\mathrm{Xmax}-\mathrm{Xo}}{\mathrm{Xo}} * \mathrm{e}^{-\mu \mathrm{t}}}
$$

(Ecuación 1)

Xo $=$ concentración de biomasa inicial en $\mathrm{g} \mathrm{L}^{-1}$

Xmax $=$ concentración de biomasa máxima producida en $\mathrm{g} \mathrm{L}^{-1}$ $\mu=$ tasa específica de crecimiento en $\mathrm{h}^{-1}$

6.5.5 Determinación de actividad enzimática mediante la cuantificación de azúcares reductores por el método de Nelson-Somogyi.

Se trabajó con el sobrenadante recolectado después de la centrifugación de las muestras tomadas durante la fermentación.

Se midió el aumento de azúcares reductores por el método de Nelson (1944) con algunas modificaciones como se describe a continuación: A un tubo de ensayo con $9.0 \mathrm{ml}$ de ácido poligalacturónico (sigma) al $0.1 \%$ (preparado en buffer de acetatos $0.1 \mathrm{M} \mathrm{pH}$ 5.0) se le adicionó $1 \mathrm{ml}$ de la solución de la enzima (extracto enzimático extracelular). El tubo se mantuvo en un baño de agua a $30^{\circ} \mathrm{C}$. Se tomó 
$1 \mathrm{ml}$ de la mezcla de reacción en los tiempos 1, 5, 10 y $15 \mathrm{~min}$, el volumen de cada muestra se colocó en diferentes tubos y se adicionó inmediatamente después $1 \mathrm{ml}$ del reactivo I de Nelson-Somogyi (apéndice 1) con el cual se detuvo la reacción.

Los tubos se incubaron en un baño de agua en ebullición durante 20 min. Transcurrido el tiempo se enfriaron los tubos y se les agregó $1 \mathrm{ml}$ del reactivo II de Nelson-Somogyi (apéndice 1) y se agitaron vigorosamente. Finalmente se les agregaron $17 \mathrm{ml}$ de agua destilada y se agitaron. Se realizó la lectura de absorbancia en un espectrofotómetro Shimadzu UV-1601 a una longitud de onda de $520 \mathrm{~nm}$. Todas las determinaciones se realizaron por duplicado. Finalmente los resultados de absorbancia se interpolaron en una curva patrón realizada con una solución de ácido galacturónico $(\mathrm{mg} / \mathrm{ml})$.

La unidad de endo-PG (uPG) fue definida como la cantidad de enzima que libera 1 $\mu$ mol de azúcares reductores por minuto. La actividad específica fue definida como la actividad enzimática por $\mathrm{mg}$ de biomasa de levadura. $\left(\mathrm{UPG} \mathrm{mg}^{-1}\right)$.

6.6. Expresión del gen bajo condiciones aerobias y anaerobias

\subsubsection{Obtención de cDNA}

6.6.1.1 Obtención del paquete celular. 
Se recolectó en tubos Nalgene (Thermoscientific, Rochester N.Y) de $50 \mathrm{ml}$ un volumen de $15 \mathrm{ml}$ de medio a partir de las fermentaciones. Se centrifugaron a $3020 \times g$ en una centrifuga durante 5 min a $4^{\circ} \mathrm{C}$.

Después de la centrifugación, se separó el sobrenadante y se conservó en un tubo Nalgene de $50 \mathrm{ml}$ para determinar la actividad enzimática. A la pastilla celular se le adicionó $1 \mathrm{ml}$ de agua DEPC estéril y se colectó en tubos Eppendorf de $1.5 \mathrm{ml}$. La pastilla celular se congeló en ultracongelador a $-70^{\circ} \mathrm{C}$ para la posterior extracción de RNA.

\subsubsection{Extracción de RNA}

Para realizar la extracción de RNA total a partir de las muestras de la fermentación se utilizaron diferentes metodologías con la finalidad de seleccionar aquella en la cual se obtuvieran los mejores resultados.

La metodología 1 consistió en utilizar el Kit de extracción Purelink RNA minikit de la marca Invitrogen (USA) siguiendo las instrucciones del proveedor.

El método de extracción 2 consistió en una extracción con Buffer LETS y posteriormente una purificación con buffer de acetatos-SDS calentando la muestra a $100{ }^{\circ} \mathrm{C}$ durante 5 min (Rivas et al 2001; Bleve et al. 2003).

La metodología 3 consistió en hacer la extracción de RNA con buffer LETS (200mM LiCl, $20 \mathrm{mM}$ EDTA, $20 \mathrm{mM}$ Tris- $\mathrm{HCl} \mathrm{pH}$ 8, 0.4\% SDS) y posteriormente 
purificar con fenol/cloroformo/alcohol isoamílico (25:24:1) (Bleve et al. 2003; Mannan, et al. 2009).

Cuando se utilizó el Purelink RNA minikit de la marca Ambion, se realizaron algunas modificaciones que a continuación se describen.

Se preparó el buffer de lisis justo antes de ser utilizado adicionando $10 \mu \mathrm{l}$ de $\beta$ mercaptoetanol por $1 \mathrm{ml}$ de buffer.

Se depositaron aproximadamente $250 \mu$ de perlas lavadas en ácido (425-600 $\mu \mathrm{m}$; Sigma) en tubos Eppendorf de $1.5 \mathrm{ml}$ y se mantuvieron en hielo. Se colectaron las células a partir del cultivo de levaduras centrifugando a $12000 \times \mathrm{g}$ a $4{ }^{\circ} \mathrm{C}$ durante 5 $\min$.

Después de centrifugar, se separó el sobrenadante del pellet. Al pellet se le adicionaron $0.5 \mathrm{ml}$ del buffer de lisis preparado con $\beta$-mercaptoetanol y se homogenizó el paquete celular en vortex a máxima velocidad durante 10 a 15 s.

Se transfirió la suspensión celular a cada uno de los tubos Eppendorf que contenían las perlas de vidrio. El resto de la extracción se llevó a cabo de acuerdo a las indicaciones del fabricante.

Se cuantificó la concentración de RNA extraído con el equipo NanoDrop 2000 (Thermoscientific) y se obtuvo también la relación de $260 / 280$ nm para conocer la calidad del RNA.

Se realizó un gel de agarosa al 1\% en condiciones nativas (no desnaturalizante) para observar las bandas y calidad del RNA extraído. La electroforesis se realizó a $60 \mathrm{~V}$ durante 90 min utilizando buffer TAE 1X como buffer de corrida. 


\subsubsection{Tratamiento con DNAsa a las muestras de RNA extraído}

Con la finalidad de eliminar el DNA genómico que pudiera interferir en la cuantificación de la expresión del gen de la endo-PG, se utilizó el kit RNase-Free DNase (Promega Madison WI, USA). La reacción se llevó a cabo con 100 ng de RNA total, se adicionaron $2 \mu \mathrm{L}$ de DNAsa, $2 \mu \mathrm{L}$ de buffer de la enzima y se llevó a un volumen final de reacción de $20 \mu \mathrm{l}$ con agua estéril libre de RNAsas. Se incubó $1 \mathrm{~h}$ a $37^{\circ} \mathrm{C}$, después de este tiempo se adicionaron $2 \mu \mathrm{l}$ de solución stop y se incubó a $65{ }^{\circ} \mathrm{C}$ durante 10 min para inactivar la enzima. Las muestras se conservaron a $-70^{\circ} \mathrm{C}$ hasta proceder con la reacción de transcripción.

\section{6.1. 4 Transcripción inversa}

La transcripción inversa (obtención de cDNA) se realizó a partir de $14 \mu \mathrm{L}$ de las muestras de RNA tratadas con DNAsa utilizando el RT primer mix, RT buffer y la transcriptasa inversa del kit Quantitec Reverse Transcription (Qiagen Hilden Germany), siguiendo las indicaciones de reacción descritas por el fabricante.

\subsubsection{Diseño de cebadores y sondas de hidrólisis para el PCR cuantitativo}

Para el diseño de cebadores y sondas de hidrólisis (Taqman) se utilizó el software proporcionado en la página web del IDT (Integrated DNA technologies), tomando como referencia los genes reportados en la base de datos del NCBI. En el caso del gen EPG se utilizó la secuencia con No. de acceso AY426825 la cual 
corresponde al gen de la enzima endo-PG, como genes de referencia 0 normalizadores se utilizaron el gen $18 S$ No. de acceso AB054675 y gen actina (ACT1) No. de acceso AJ389078, ambas secuencias reportadas para genes de la levadura Kluyveromyces marxianus.

Debido a que el software arroja varias opciones en el juego de primers-sonda se consideraron los siguientes criterios para la selección.

Para las sondas:

Criterio Tm (melting temperature): la $\mathrm{Tm}$ de la sonda Taqman debe ser $10{ }^{\circ} \mathrm{C}$ mayor que la Tm de los cebadores.

Criterio de longitud: Los cebadores deber tener de 15-30 bases de longitud

Contenido de GC: El contenido de GC debe ser idealmente de $30-80 \%$. Si hay un contenido mayor debe utilizarse una mayor temperatura de hibridación y cosolventes.

Grapa de GC: El número total de GC's en los últimos 5 nucleótidos en el extremo 3 'del primer no debe exceder de 2.

Las sondas no deben tener corridas de nucleótidos idénticos (especialmente 40 más guaninas consecutivas)

Para los cebadores

Diseñar los cebadores lo más cerca posible a la sonda sin que se solapen 
Longitud del amplicón: El máximo tamaño del amplicón no debe exceder de 400 bases. Idealmente debe ser de 50-150 bases.

Longitud de 15-30 bases

La temperatura de fusión debe estar entre $58-60{ }^{\circ} \mathrm{C}$. La Tm de ambos cebadores debe ser igual o una diferencia de hasta $1^{\circ} \mathrm{C}$.

Evitar complementariedad interna y complementariedad entre los cebadores especialmente en los extremos $3^{\prime}$.

Diseñarlos en las uniones exón-exón o en exones diferentes.

Verificar la especificidad de los cebadores realizando la amplificación de los genes por PCR. 
Tabla 1. Características de los cebadores diseñados para la amplificación de los genes EPG, 18S y ACT1 por medio de PCR tiempo real.

\begin{tabular}{|c|c|c|c|c|}
\hline Gen & $\begin{array}{l}\text { No. Acceso } \\
\text { GenBank }\end{array}$ & Descripción & $\begin{array}{l}\text { Secuencia de cebadores y } \\
\text { sondas } \\
\left(\begin{array}{lll}\left(5^{\prime}\right. & 3^{\prime}\end{array}\right)\end{array}$ & $\begin{array}{c}\text { Tamaño } \\
\text { del } \\
\text { producto } \\
\text { de PCR } \\
\text { (pb) }\end{array}$ \\
\hline EPG & AY426825 & $\begin{array}{c}\text { Enzima endo-PG de } K \text {. } \\
\text { marxianus }\end{array}$ & $\begin{array}{l}\text { fw-cac ttc ttg tcc aac act atc t } \\
\text { rw-ctg taa gcg gaa gag tca ac } \\
\text { Sonda FAM-agg tag caa ggt } \\
\text { ccc aat cac caa-TAMRA }\end{array}$ & 161 \\
\hline $18 \mathrm{~S}$ & AB054675 & Gen ribosomal & $\begin{array}{l}\text { fw- aat tcc agc tcc agt agc gt } \\
\text { rw-gaa gga aag atc cgg ttg aa } \\
\text { Sonda FAM-acc ggc caa cca } \\
\text { gac cca aa-TAMRA }\end{array}$ & 123 \\
\hline ACT & AJ389078 & $\begin{array}{l}\text { Proteína del } \\
\text { citoesqueleto }\end{array}$ & $\begin{array}{l}\text { Fw- aag aaa tgc aaa ccg ctt } \\
\text { ct } \\
\text { Rw- aac aga tgg atg gaa caa } \\
\text { agc } \\
\text { Sonda FAM- caa atg gtg ata } \\
\text { act tga caa tct ggc- TAMRA }\end{array}$ & 125 \\
\hline
\end{tabular}




\subsubsection{Ensayos de validación del método de PCR cuantitativo}

Con la finalidad de verificar si los cebadores diseñados son específicos, es decir, que amplifican un solo producto, y para cerciorarse de que no hay formación de estructuras secundarias tales como dímeros de cebadores, se llevó a cabo una reacción de PCR con DNA genómico.

Se utilizaron 10-25 ng de DNA genómico como molde empleando los cebadores diseñados en este trabajo, cuya secuencia para la amplificación del gen EPG es la siguiente: cebador fw (cac ttc ttg tcc aac act atc t) y cebador rw (ctg taa gcg gaa gag tca ac) y para el gen normalizador $18 S$ la secuencia del primer fw (aat tcc agc tcc agt agc gt) y primer rw (gaa gga aag atc cgg ttg aa). La reacción de PCR se llevó a cabo para cada gen en $25 \mu$ de volumen final con las siguientes concentraciones de reactivos: buffer PCR 1X, $2.5 \mathrm{mM}$ de $\mathrm{MgCl}_{2}, 200 \mu \mathrm{m}$ de dNTP mix, $0.15 \mu \mathrm{m}$ de cada cebador, $0.01 \mathrm{UI}$ de Platinum Taq DNA polimerasa. Las condiciones de reacción de PCR fueron: desnaturalización inicial, $94{ }^{\circ} \mathrm{C}$ durante 2 min; 30 ciclos de: $94{ }^{\circ} \mathrm{C}$ durante $1 \mathrm{~min}$, se realizó un gradiente de temperatura de 52 a $60^{\circ} \mathrm{C}, 72{ }^{\circ} \mathrm{C}$ durante $1 \mathrm{~min}$ y extensión final de $72{ }^{\circ} \mathrm{C}$ durante $5 \mathrm{~min}$. Los productos de amplificación se analizaron en un gel de agarosa al $2 \%$ teñidos con rojo texas $(0.5 \mu \mathrm{g} / \mathrm{ml})$ y visualizados bajo luz UV.

Con la finalidad de verificar el diseño adecuado de las sondas de hidrólisis para la cuantificación de la expresión del gen, se llevaron a cabo reacciones de amplificación en el equipo de PCR tiempo real para cada uno de los genes. 
Para las reacciones de PCR tiempo real se seleccionó la temperatura de hibridación en la cual se observó la amplificación de una sola banda para cada uno de los genes y también en la que no se presentara la formación de dímeros de primers.

Se emplearon los cebadores y sondas descritos en la Tabla 1 para amplificar fragmentos de los genes EPG, $18 S$ y $A C T 1$ diseñadas en este trabajo. Se llevó a cabo la reacción de PCR para cada uno de los genes en $25 \mu \mathrm{l}$ de volumen final con las siguientes concentraciones de reactivos: Taqman PCR Universal master mix $1 \mathrm{X}, 0.15 \mu \mathrm{m}$ de cada cebador, $0.05 \mu \mathrm{m}$ de la sonda y $4 \mu \mathrm{l}$ de cDNA. Las condiciones de reacción de PCR fueron: $50{ }^{\circ} \mathrm{C}$ durante $2 \min , 95{ }^{\circ} \mathrm{C} 10 \min$ y 40 ciclos a $95{ }^{\circ} \mathrm{C}$ durante 15 seg y $54{ }^{\circ} \mathrm{C}$ durante $1 \mathrm{~min}$. Las reacciones de PCR se realizaron por triplicado en el equipo Rotor Gene 5 adquiriendo la fluorescencia del fotocromo reportero para verificar la amplificación.

Se realizaron 4 diluciones en serie con factor 2 de dilución del cDNA obtenido (20, $10,5,2.5 \mathrm{ng} / \mathrm{\mu l})$. Las reacciones de PCR se llevaron a cabo en un volumen final de $25 \mu \mathrm{L}$ con las siguientes concentraciones de reactivos: Taqman PCR Universal master mix $1 \mathrm{X}, 0.15 \mu \mathrm{m}$ de cada cebador, $0.05 \mu \mathrm{m}$ de la sonda y $4 \mu \mathrm{l}$ de cDNA. Condiciones de reacción de PCR: $50{ }^{\circ} \mathrm{C}$ durante $2 \mathrm{~min}, 95^{\circ} \mathrm{C}$ durante 10 min y 40 ciclos a $95{ }^{\circ} \mathrm{C}$ durante $15 \mathrm{seg}$ y $54^{\circ} \mathrm{C}$ durante $1 \mathrm{~min}$. Las reacciones de PCR se realizaron por triplicado en el equipo Rotor Gene 5 adquiriendo la fluorescencia del fotocromo reportero para verificar la amplificación. 
6.6.4 Cuantificación de la expresión del gen de la endo-PG en las diferentes condiciones de crecimiento.

Para cuantificar la expresión del gen de la endo-PG en las diferentes condiciones de crecimiento se llevó a cabo un PCR tiempo real a partir de cDNA obtenido en las fermentaciones. Las muestras se amplificaron por triplicado en las condiciones de reacción descritas en el apartado anterior. Se realizó un control negativo de la reacción de PCR incluyendo todos los reactivos excepto cDNA. En todas las muestras se consideró un umbral de fluorescencia de 0.05 RFU. El nivel de expresión relativa del gen blanco se calculó de acuerdo a lo reportado por Hellemans et al. (2007), Ecuación 2.

$$
N R Q=\frac{E_{g o i}^{\Delta C t, g o i}}{\sqrt[f]{\prod_{o}^{f} E_{r e f_{o}}^{\Delta C t, r e f_{o}}}}
$$

Ecuación 2

$\mathrm{NRQ}=$ Cantidad relativa normalizada

$E_{g o i}=$ Eficiencia de amplificación del gen blanco

$\Delta \mathrm{Ct}_{\mathrm{goi}}=$ Diferencia en los valores $\mathrm{Ct}$ del gen blanco en las condiciones bajo estudio

$f=$ Número de genes de referencia utilizados para normalizar

$\pi=$ Producto

$E_{\text {refo }}=$ Eficiencia de amplificación del gen de referencia cero

$\Delta \mathrm{Ct}_{\text {refo }}=$ Diferencia en los valores de $\mathrm{Ct}$ del gen de referencia cero en las condiciones bajo estudio 


\section{RESULTADOS Y DISCUSIÓN}

7.1 Extracción de DNA e identificación del gen de la enzima endo-PG en la cepa K. marxianus CDBBL-278

Se llevó a cabo la extracción de DNA y posteriormente se realizó el PCR para amplificar el gen de la enzima endo-PG de la cepa de K. marxianus CDBBL-278, utilizando los cebadores descritos por Sieiro et al. (2009), obteniéndose un producto de PCR de aproximadamente $1000 \mathrm{pb}$ como lo describieron dichos autores (Figura 3). El producto se purificó de acuerdo a lo descrito en la metodología y finalmente se envió a secuenciar al Laboratorio Divisional de Biología Molecular de la UAM Iztapalapa.

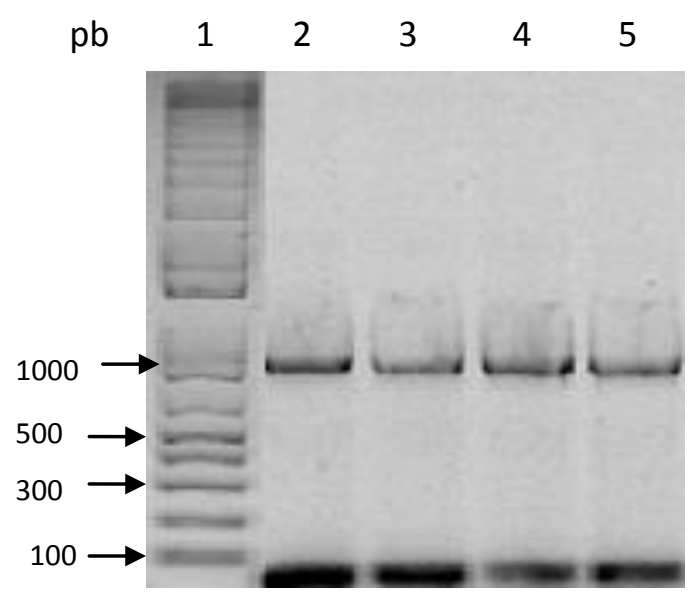

Figura 3. Electroforesis en gel de agarosa con los productos de la purificación del gen EPG obtenidos con el kit Montage PCR (Millipore). Carriles 2 al 5 productos de PCR de la cepa de K. marxianus CDBBL-278, carril 1 marcador de tamaño de DNA. 
A partir de las secuencias obtenidas con cada cebador se generó la secuencia consenso mediante el software Bioedit, con una longitud final de 945 nucleótidos, los cuales, al ser traducidos resultaron en 315 aminoácidos que corresponden a la enzima endo-PG de K. marxianus CDBBL-278. La secuencia de nucleótidos se depositó en la base de datos del Gen-Bank con número de acceso KU240011. Cabe señalar que la secuencia de nucleótidos y aminoácidos obtenida es menor a las reportadas por Siekstele et al. (1999) y Sieiro et al. (2009) ya que con los oligonucleótidos utilizados en este trabajo sólo se amplificó la proteína madura y no se incluyeron los 25 aminoácidos iniciales que constituyen la secuencia señal (Siekstele et al. 1999). Para examinar la relación de la secuencia de nucleótidos con otras secuencias reportadas en la base de datos del GenBank, se llevó a cabo una comparación por medio de BLAST. Los resultados obtenidos se muestran en la tabla 2. 
Tabla 2. Comparación mediante BLAST de las secuencias de nucleótidos con alineamientos significativos con el gen de K. marxianus CDBBL-278

\begin{tabular}{|c|c|c|c|}
\hline Descripción & $\begin{array}{l}\text { Valor } \\
\text { E }\end{array}$ & $\begin{array}{l}\text { Identidad } \\
\qquad \%)\end{array}$ & $\begin{array}{c}\text { No. de acceso en el } \\
\text { GenBank } \\
\text { (nucleótidos) }\end{array}$ \\
\hline $\begin{array}{l}\text { Fragmento del cromosoma } 1 \text { de Kluyveromyces } \\
\text { marxianus, cepa NBRC } 1777\end{array}$ & 0.0 & 99 & AP014599.1 \\
\hline $\begin{array}{l}\text { Fragmento del cromosoma } 1 \text { de Kluyveromyces } \\
\text { marxianus cepa CBS4857 }\end{array}$ & 0.0 & 99 & СР015054.1 \\
\hline $\begin{array}{l}\text { Fragmento del cromosoma } 1 \text { Kluyveromyces } \\
\text { marxianus cepa CCT } 7735 \text { (UFV-3) }\end{array}$ & 0.0 & 99 & СР009303.1 \\
\hline $\begin{array}{l}\text { Fragmento del cromosoma } 1 \text { Kluyveromyces } \\
\text { marxianus cepa DMKU3-1042 }\end{array}$ & 0.0 & 99 & AP012213.1 \\
\hline $\begin{array}{l}\text { Endo-PG Kluyveromyces marxianus gen EPG1 } \\
\text { alelo EPG1-2 Cepa CECT1043 }\end{array}$ & 0.0 & 99 & AY426825.1 \\
\hline $\begin{array}{l}\text { Endo-PG Kluyveromyces marxianus gen EPG1. } \\
\text { Cepa BKMY-719 }\end{array}$ & 0.0 & 98 & AJ000076.1 \\
\hline
\end{tabular}


Se observa en la Tabla 2 que la secuencia de nucleótidos obtenidos para el gen de la endo-PG de la cepa de K. marxianus CDBBL-278 tiene un $99 \%$ de similitud con el gen EPG1, alelo EPG1-2 (cepa CECT 1043) reportado por Sieiro et al. (2009), así como también con un fragmento del cromosoma 1 reportado para otras cepas de K. marxianus (Inokuma et al. 2015; Lertwattanasakul et al. 2015; Silveira et al. 2014), lo cual podría indicar que el gen EPG se encuentra en el cromosoma 1 en $K$. marxianus. Por otro lado, el gen de la endo-PG de $K$. marxianus CDBBL278 tiene un 98\% de similitud con el alelo del gen EPG1 (cepa BKMY-719).

Además de los valores del porcentaje de identidad, se muestra en la tabla el valor de expectancia $(E)$, el cual indica el nivel de significancia de un alineamiento: cuánto más pequeño es el valor $\mathrm{E}$, más significativo es el alineamiento.

7.2 Distancia filogenética de la endo-PG de K. marxianus CDBBL-278 con otras endo-PG de levaduras y hongos.

Se realizó también la comparación de la secuencia de aminoácidos de la endo-PG de K. marxianus CDBBL-278 (No. de acceso ANB44747.1) con otras proteínas endo-PG mediante un BLASTp, con la finalidad de examinar la similitud entre ellas. En el caso de otras endo-PG de K. marxianus, se encontró $99 \%$ de similitud con la proteína con No. de acceso AAR84199.1 codificada por el gen EPG1-2 cepa CECT 1043 reportada por Sieiro et al. (2009) y un 97\% de similitud con la proteína No de acceso CAA03900.1, codificada por el gen EPG1 cepa BKMY-719 reportado por Siekstele et al. (1999). Por otro lado, se encontró que la secuencia 
de aminoácidos de la endo-PG de K. marxianus CDBBL-278 presenta similitud de entre 59 y $61 \%$ con poligalacturonasas de Saccharomyces cerevisiae, Saccharomyces uvarum, Saccharomyces pastorianus y Saccharomyces paradoxus, así como con poligalacturonasas de hongos (Tabla 3). 
Tabla 3. Comparación de la secuencia de aminoácidos para la endo-PG de Kluyveromyces marxianus CDBBL-278

\begin{tabular}{|c|c|c|}
\hline Descripción & Identidad (\%) & $\begin{array}{l}\text { No. de acceso de la } \\
\text { proteína en GenBank }\end{array}$ \\
\hline Kluyveromyces marxianus cepa DMKU3-1042 (cromosoma 1) & 99 & ВАО38138.2 \\
\hline Kluyveromyces marxianus cepa CECT 1043 (Gen EPG1-2) & 99 & AAR84199.1 \\
\hline Kluyveromyces marxianus cepa BKMY-719 (gen EPG1) & 97 & CAA03900.1 \\
\hline Penicillium sp. CGMCC 1669 & 93 & AEL22832.1 \\
\hline Kluyveromyces wickerhamii & 70 & BAB69585.1 \\
\hline Saccharomyces pastorianus & 61 & CCA61339.1 \\
\hline Saccharomyces uvarum & 61 & CCA61336.1 \\
\hline Saccharomyces cerevisiae Fosters B & 59 & EGA58088.1 \\
\hline Saccharomyces sp. 'boulardi' & 59 & KOH49950.1 \\
\hline Saccharomyces arborícola H-6 & 59 & EJS43013.1 \\
\hline Aerobasidium melanogenum CBS110374 & 55 & KEQ64384.1 \\
\hline Verticillium alfalfae VaMs. 102 & 54 & XP_003002875.1 \\
\hline Thielavia arenaria & 54 & AIZ95162.1 \\
\hline Aureobasidium subglaciale EXF-2481 & 54 & XP_013341029.1 \\
\hline Talaromyces cellulolyticus & 54 & GAM33350.1 \\
\hline Aspergillus sojae & 53 & BAK22527.1 \\
\hline Pestalotiopsis fici W106-1 & 53 & XP_007836731.1 \\
\hline
\end{tabular}




\begin{tabular}{|c|c|c|}
\hline Talaromyces mRNAeffei PM1 & 53 & KFX46954.1 \\
\hline Penicillium griseoroseum & 52 & AAF06810.1 \\
\hline Colletotrichum fioriniae PJ7 & 52 & XP_007599497.1 \\
\hline Penicillium camemberti & 52 & CRL23357.1 \\
\hline Venturia nashicola & 51 & BAG72101.1 \\
\hline Penicillium expansum & 51 & KGO43284.1 \\
\hline Penicillium roqueforti FM164 & 53 & CDM27702.1 \\
\hline Fusarium langsethiae & 52 & KPA37956.1 \\
\hline Cryphonectria parasítica & 52 & AAB36616.1 \\
\hline Trichoderma virens & 51 & AHK61121.1 \\
\hline
\end{tabular}

\section{Continuación Tabla 3.}


Con la finalidad de comparar la secuencia deducida de aminoácidos de la endoPG de K. marxianus CDBBL-278 (No. de acceso ANB44747.1) con la proteína EPG1 de la cepa CECT 1043 (No. de acceso CAA03900.1) y la proteína EPG1-2 de la cepa BKMY-719 (No. de acceso (AAR84199.1), se realizó un alineamiento múltiple mediante Clustal W. Este alineamiento reveló que la proteína codificada por el gen EPG1-2 (cepa CECT 1043) y la secuencia de aminoácidos de la endoPG de K. marxianus CDBBL-278 tienen una valina en la posición 99, mientras que en la secuencia de la proteína EPG1 (cepa BKMY-719) este aminoácido no aparece (Figura 4). Además de la diferencia de este aminoácido entre las tres proteínas analizadas, en la Figura 4 se resaltan también otros aminoácidos que difieren entre las secuencias de las mismas, por ejemplo entre la proteína EPG1-2 de la cepa CECT 1043 y la endo-PG de la cepa CDBBL-278 los aminoácidos 55, 95, 107, 145, 172 y 305 coinciden entre sí y no con los mismos comparados con la proteína EPG1 de la cepa BKMY-719. Por otro lado, se observan en la Figura 4 otras diferencias entre los aminoácidos de la endo-PG de las cepas analizadas mostrando que la secuencia de aminoácidos de la endo-PG de $K$. marxianus CDBBL-278 coincide con algunos aminoácidos del gen EPG1 (aminoácidos 41 y 69) y no con los mismos en la proteína EPG1-2. Así mismo se observa que entre las tres secuencias hay similitud, además de otros aminoácidos, en la secuencia conservada del sitio activo (aminoácidos 193-206) y uno de los dos sitios hipotéticos de glicosilación (aminoácidos 165-168) reportados anteriormente por Siekstele et al. (1999). 


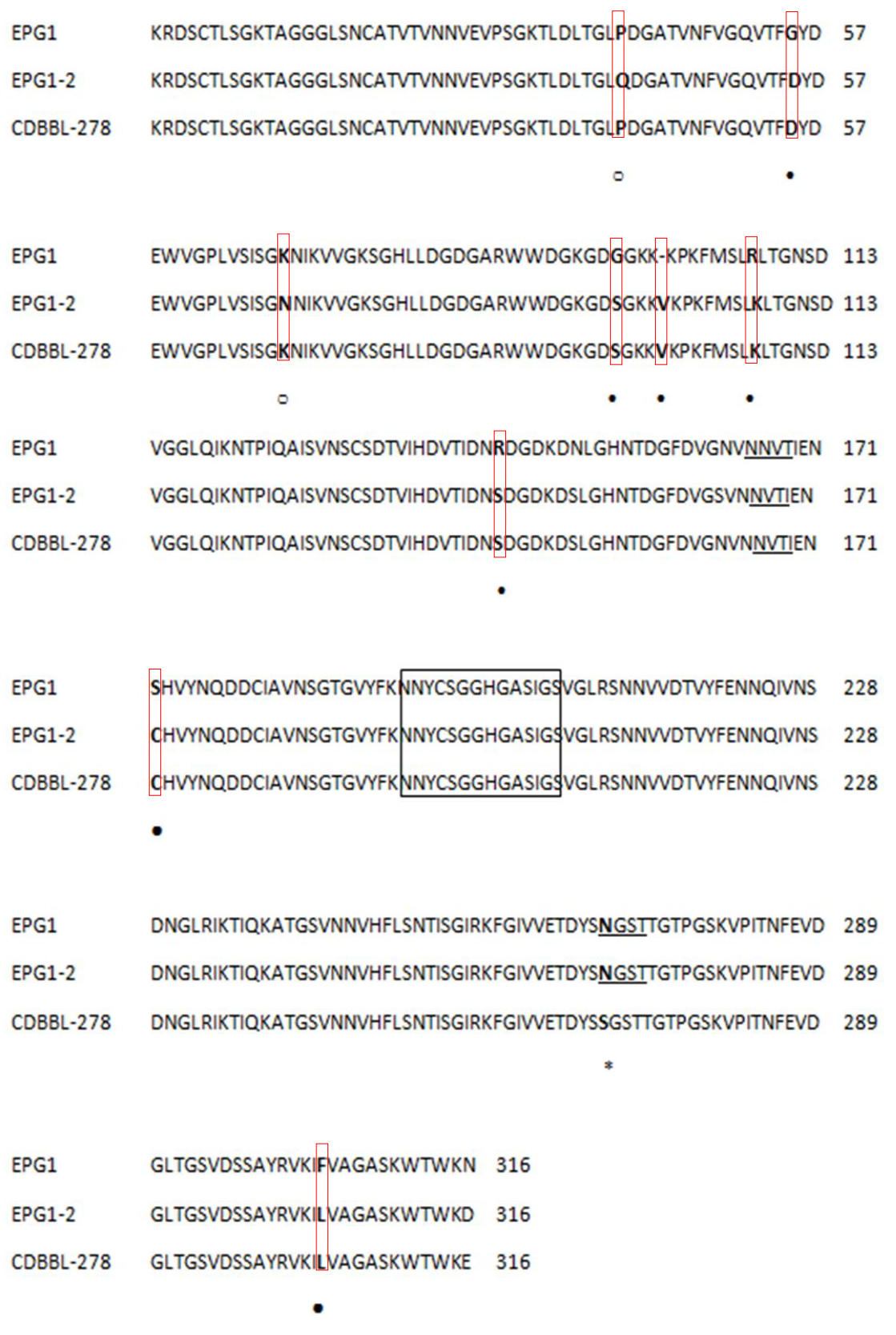

Fig. 4 Alineamiento de la secuencia deducida de aminoácidos de la endo-PG de $K$. marxianus CDBBL-278 (KU240011) con la proteína EPG1 (cepa BKMY-719, No de acceso CAA03900.1) y proteína EPG1-2 (cepa CECT 1043 No. de acceso AAR84199.1). Las diferencias de los aminoácidos entre las proteínas EPG1 y la CDBBL-278 se indican con •; mientras que los aminoácidos que difieren entre la proteína EPG1-2 y la CDBBL278 se indican con $\circ$; el recuadro indica el sitio activo de la poligalacturonasa; el sitio hipotético de glicosilación se indica subrayado; el * indica sustituciones conservadoras. 
Este análisis permite concluir que a pesar de que la endo-PG de la cepa CDBBL278 guarda una mayor similitud con la secuencia de aminoácidos presentada por la endo-PG de la cepa CECT 1043 (codificada por el alelo EPG 1-2), el gen de endo-PG de $K$. marxianus CDBBL-278 es una variante distinta no reportada previamente.

Por otra parte, se llevó a cabo la reconstrucción filogenética de la endo-PG de $K$. marxianus CDBBL-278 comparando la secuencia (No. de acceso ANB44747.1) con otras secuencias reportadas para endo-PG de levaduras y hongos (Tabla 3). Estas endo-PG se agruparon en dos grandes clados (Pezizomycotina y Saccharomycotina). Como se puede observar en la Figura 5, dentro del grupo Saccharomycotina se encuentran las poligalacturonasas de levaduras del género Saccharomyces y Kluyveromyces. La endo-PG de K. marxianus CDBBL-278 representa un linaje evolutivo separado entre un clado fuertemente soportado (valor de bootstrap de 98\%) formado por otras secuencias $K$. marxianus y $K$. wickerhamii (Figura 5). Dentro del grupo de Kluyveromyces se observa a su vez una división entre las endo-PG que tienen la valina adicional en la posición 123 de la proteína, lo cual indicaría que estas proteínas son ortólogas. 


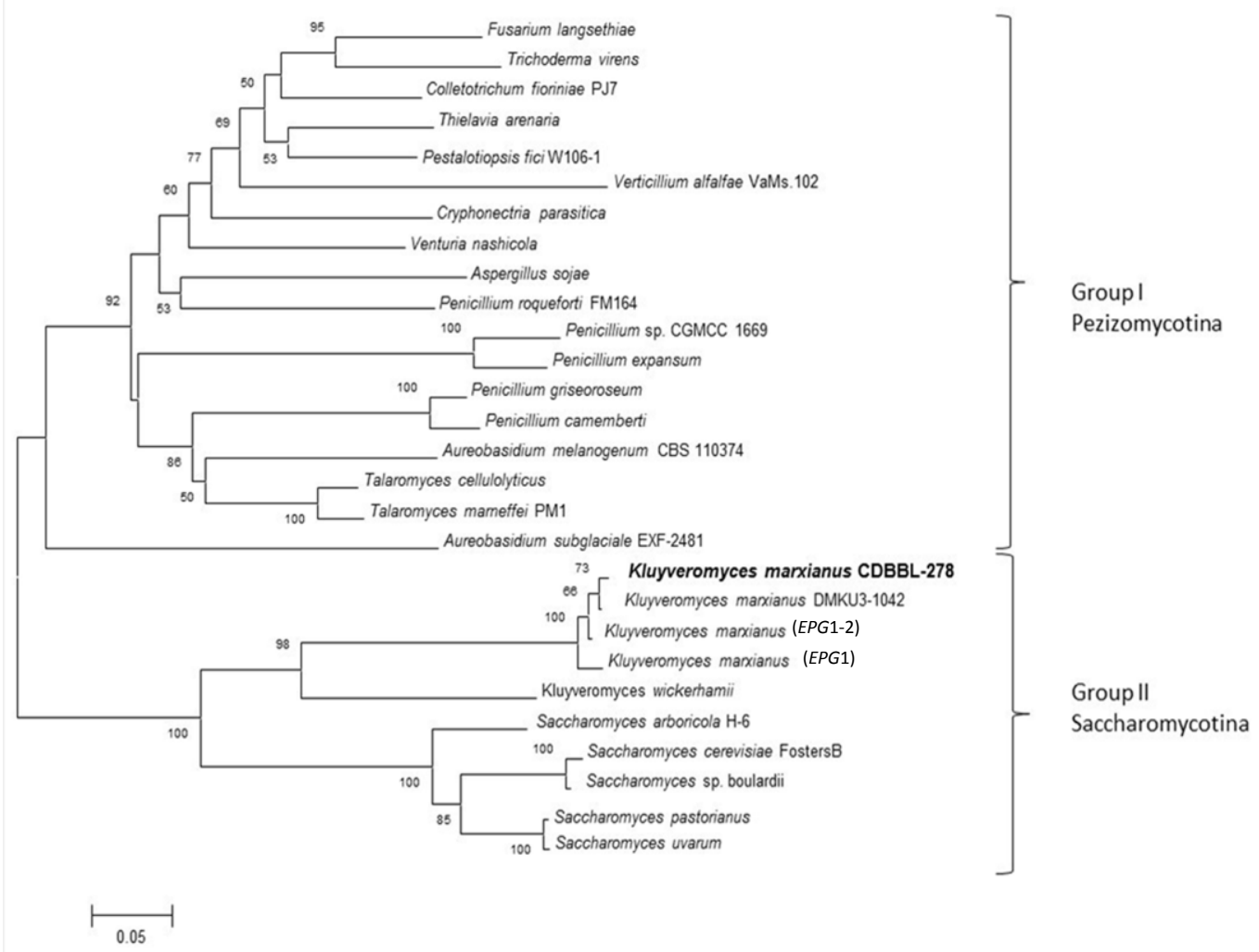

Figura 5. Árbol de máxima verosimilitud para el análisis filogenético de secuencia de aminoácidos. Los números en las ramificaciones indican el valor de bootstrap después de 1000 réplicas. La barra de escala muestra el porcentaje de disimilitud entre secuencias.

7.3 Crecimiento y actividad enzimática bajo diferentes condiciones de oxígeno disuelto

En la Figura 6 se muestra el comportamiento de la biomasa y la actividad enzimática asociada a esta, bajo la concentración de oxígeno disuelto de $60 \%$, obteniéndose una $\mu$ (velocidad específica de crecimiento) de $0.57 \mathrm{~h}^{-1}$ y un crecimiento máximo de $2.351 \mathrm{mg} / \mathrm{ml}$ a las $9 \mathrm{~h}$. La actividad enzimática específica (por mg de biomasa) cuando la concentración de oxígeno disuelto (OD) es del $60 \%$ es igual a cero (entre las cero y las tres horas de crecimiento), sin embargo se observa que conforme crece la levadura y el oxígeno disponible en el medio 
fluctúa entre el 50 y $60 \%$ de OD se presenta un aumento en dicha actividad como se muestra en la Figura 6 para los tiempos de fermentación 6 y 9 horas siendo de $0.035 \mathrm{uPG} / \mathrm{mg}$ biomasa y $0.048 \mathrm{uPG} / \mathrm{mg}$ de biomasa, respectivamente.

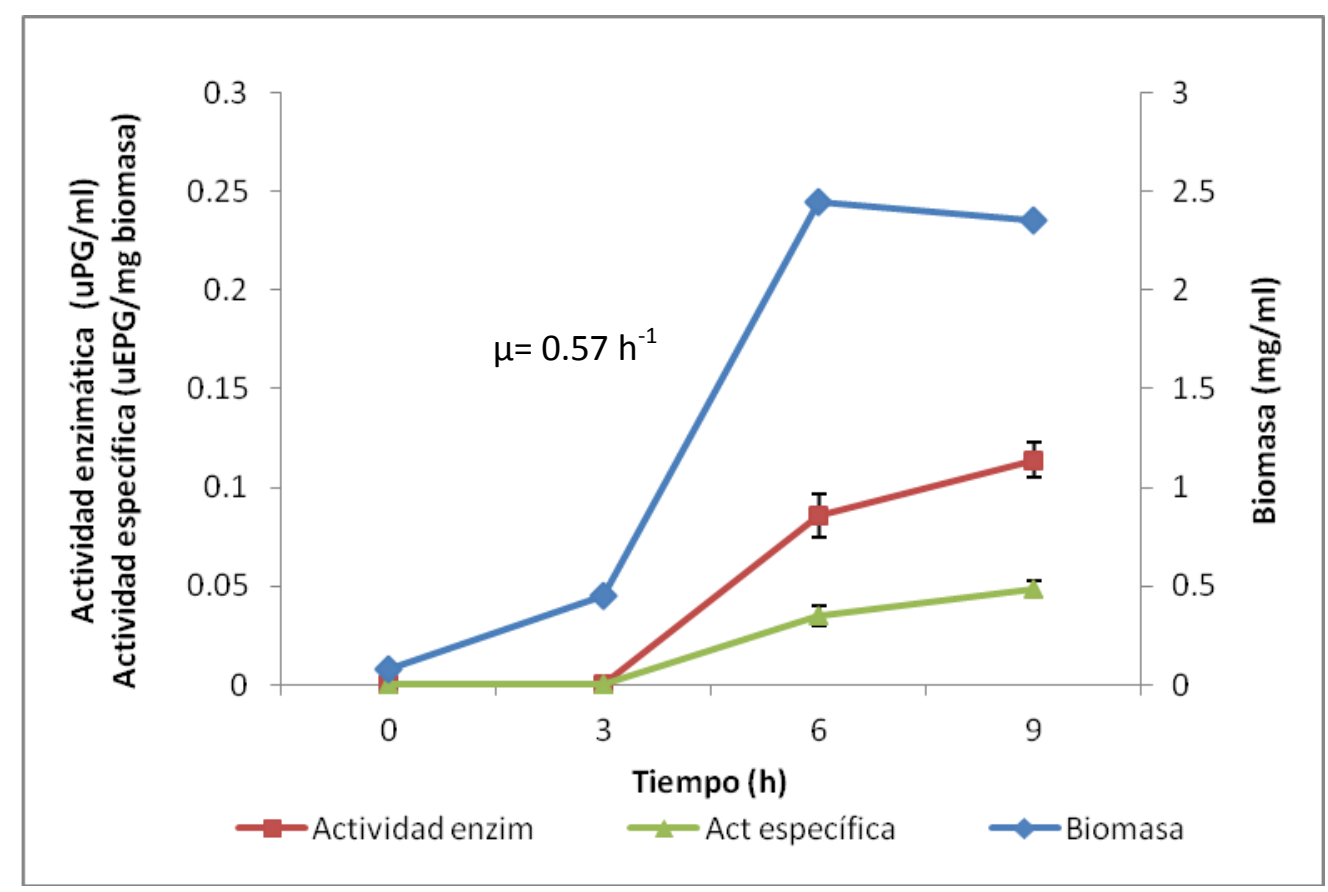

Figura 6. Crecimiento de biomasa y actividad endo-PG obtenidos en condiciones aerobias de crecimiento ( $60 \%$ de oxígeno disuelto)

En la Figura 7 se muestran los resultados obtenidos para la fermentación anaerobia. En esta fermentación se observó un menor crecimiento de la levadura resultando una $\mu$ de $0.324 \mathrm{~h}^{-1}$ con un crecimiento máximo de $0.65 \mathrm{mg} / \mathrm{ml}$ a las $9 \mathrm{~h}$. Se puede apreciar que a pesar de presentar un menor crecimiento de la biomasa, la actividad específica es hasta cinco veces mayor en comparación con la fermentación aerobia en los tiempos 6 y 9 h ( 0.130 uPG/mg biomasa y 0.233 $\mathrm{uPG} / \mathrm{mg}$ biomasa respectivamente). Estos resultados son similares a lo obtenido 
por otros autores en los que reportan que bajo una concentración de $60 \%$ de oxígeno disuelto de la actividad de la endo-PG se ve reprimida y bajo condiciones anaerobias de crecimiento la actividad enzimática aumenta (Wimborne y Rickard, 1978; Schawn et al. 1994; Cruz Guerrero et al, 1999).

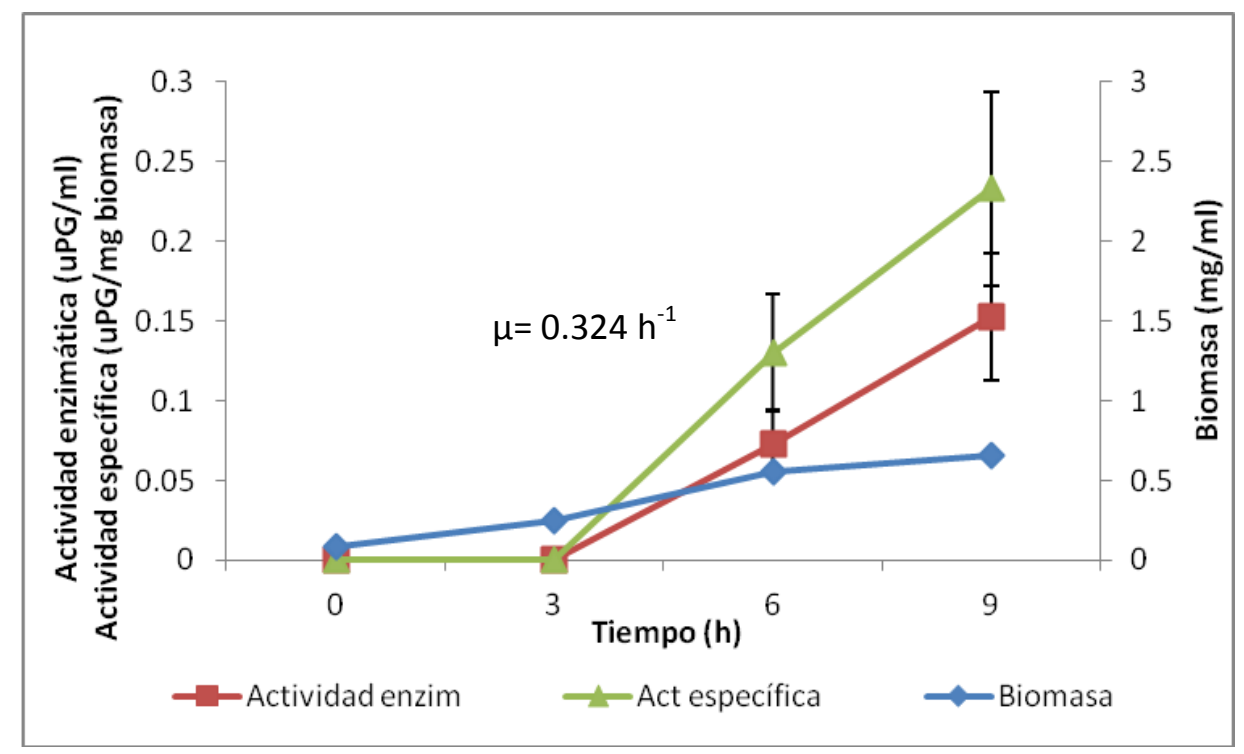

Figura 7. Crecimiento de biomasa y actividad endo-PG obtenidos en condiciones anaerobias de crecimiento ( $20 \%$ de oxígeno disuelto)

Se realizó el ajuste del crecimiento microbiano utilizando el modelo logístico (ecuación de Verhulst-Pearl) (Figura 8) cuyo resultado para la producción de biomasa en condiciones aerobias fueron de $2.56 \mathrm{mg} / \mathrm{ml}$ para el crecimiento máximo a las $9 \mathrm{~h}$, con una velocidad de crecimiento de $0.85 \mathrm{~h}^{-1}$ y para el caso de la producción de biomasa en condiciones anaerobias se obtuvo un crecimiento máximo de $0.71 \mathrm{mg} / \mathrm{ml}$ a las $9 \mathrm{~h}$, con una $\mu$ de $0.53 \mathrm{~h}^{-1}$. El ajuste al modelo 
logístico generó una correlación de 0.97 para las condiciones de crecimiento aerobio y de 0.99 para el crecimiento anaerobio; estos valores de correlación indican que el crecimiento poblacional se ajusta al modelo logístico empleado. El modelo logístico describe que una población no puede crecer indefinidamente ya que se encuentra limitada por la competencia, por los recursos alimenticios y territoriales; es decir una población estable debe llegar a un nivel de saturación característico (Neuhauser, 2004; Accinelli y Brida, 2006). Evidentemente las condiciones aerobias de crecimiento permitieron una producción más favorable de biomasa, a pesar de esto la actividad de la enzima no se ve tan favorecida como en el caso de las condiciones anaerobias en las que a pesar de la presencia de una menor biomasa la actividad enzimática fue mayor. 


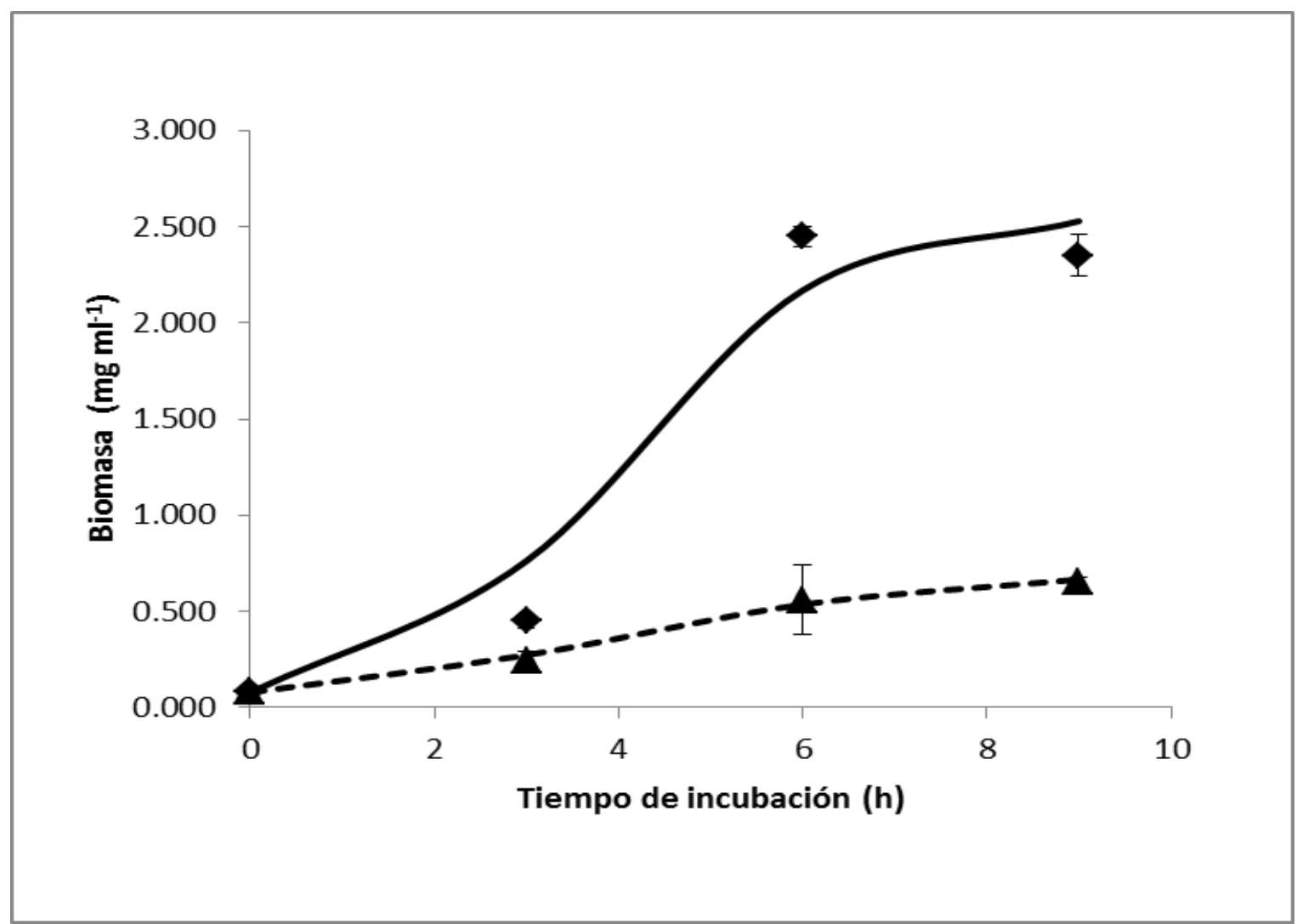

Figura 8. Ajuste del crecimiento de K.marxianus CDBBL-278 al modelo logístico bajo diferentes condiciones de oxígeno disuelto. La línea continua representa el ajuste al modelo logístico del crecimiento bajo condiciones aerobias. La línea punteada indica el crecimiento ajustado al modelo logístico bajo condiciones anaerobias El símbolo el crecimiento del microorganismo sin ajuste al modelo logístico bajo condiciones aerobias de crecimiento. El símbolo $\boldsymbol{\Delta}$ indica el crecimiento bajo condiciones anaerobias sin ajustar al modelo logístico.

A partir de estos cultivos se investigó si existe una correlación directa entre el aumento de la actividad de la endo-PG en condiciones anaerobias y un aumento en la expresión del gen. Este estudio es de gran importancia debido a que no hay 
reportes en los que se estudie la expresión del gen de enzimas poligalacturonasas que se encuentren reguladas por el oxígeno.

7.4 Montaje de la técnica de extracción de RNA

Con la finalidad de montar una técnica ideal para la extracción de RNA se ensayaron tres metodologías de extracción.

Los resultados de la extracción para cada uno de los métodos empleados se resumen en el gel de agarosa que se muestra en la Figura 9.

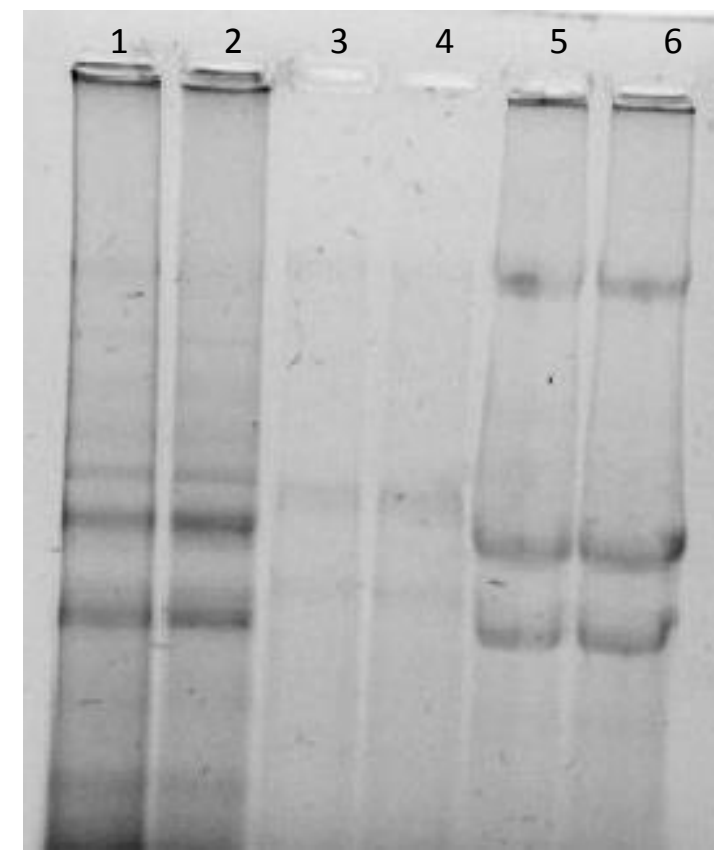

Figura 9. Electroforesis en gel de agarosa al 1\% de los productos de extracción de RNA. Carril 1 y 2: método 1 de extracción (Purelink RNA minikit); carril 3 y 4: método 2 de extracción (Buffer LETS/acetatos-SDS); carril 5 y 6: método 3 de extracción (Buffer LETS/fenol: cloroformo: isopropanol). 
Posterior a la extracción de RNA se procedió a cuantificar con el equipo Nanodrop la concentración de RNA extraída. Los resultados se muestran en la tabla 4.

Tabla 4 Cuantificación de RNA con los diferentes métodos de extracción

\begin{tabular}{|l|c|c|}
\hline \multicolumn{1}{|c|}{ Método de extracción } & Concentración (ng/ $\mathbf{\mu l )}$ & $\begin{array}{c}\text { Relación absorbancia } \\
\mathbf{( 2 6 0 / 2 8 0 )}\end{array}$ \\
\hline 1. Pure link RNA mini kit & 344.05 & 2.06 \\
\hline 2. Extracción LiCl/acetatos-SDS & 1412.6 & 2.19 \\
\hline $\begin{array}{l}\text { 3. Extracción } \\
\text { LiCl/fenol/cloroformo/isopropanol }\end{array}$ & 1767.4 & 2.11 \\
\hline
\end{tabular}

Un criterio para continuar con el proceso de obtención de cDNA y realizar el PCR cuantitativo es tener una relación de absorbancia de 260/280 igual a 2 (Vaudano et al. 2010), además de visualizar la integridad del RNA en un gel de agarosa en condiciones nativas o en un gel de agarosa en condiciones desnaturalizantes.

Se puede observar en la Tabla 4 que la relación 260/280 para las muestras extraídas se encuentra dentro de los valores adecuados para ser considerada como una buena extracción. Esta relación de 260/280 es importante ya que indica el grado de contaminación de la muestra con diferentes reactivos. En la longitud de onda de $260 \mathrm{~nm}$ se obtiene el pico máximo de absorbancia para los ácidos nucleicos y en 280 se obtiene un pico máximo de absorbancia para proteínas y 
compuestos fenólicos. Si la relación 260/280 es menor de 2, éste resultado es un indicativo de que la muestra puede contener residuos de proteínas o compuestos fenólicos los cuales pueden interferir en la reacción de PCR inhibiéndola. Si el valor de relación 260/280 es igual a dos o mayor pero en el gel de agarosa no hay presencia de bandas o éstas son muy difusas, significaría que se degradó el RNA y solo se están cuantificando los reactivos con los que se realizó la extracción. Si por el contrario se observa en el gel una sola banda intensa en la parte superior esto indica la presencia de DNA genómico. Por tanto es importante además de cuantificar realizar el gel de agarosa.

En la Figura 9 se muestra el gel de agarosa al $1 \%$ en condiciones nativas donde se observan las bandas características del gen ribosomal 28S (banda superior) y 18S (banda inferior) en todas las muestras, siendo más marcadas (mayor intensidad) y con menos contaminación de DNA genómico en la extracción realizada con el kit.

Con base en estos resultados se concluyó que el método en el que se extrae RNA de mejor calidad es con el Pure link RNA minikit (método 1) por lo que con este método se realizaron las extracciones a partir de las fermentaciones.

7.4.1 Extracción de RNA en condiciones aerobias y anaerobias de crecimiento

Después de los experimentos de crecimiento de K. marxianus CDBBL-278 bajo las diferentes condiciones de aireación, se llevó a cabo la extracción de RNA de 
acuerdo a lo descrito en la metodología. En la Figura 10A se muestra el gel de agarosa de la extracción de RNA en condiciones de crecimiento aerobio donde se observan las bandas características de RNA ribosomal $28 \mathrm{~S}$ y $18 \mathrm{~S}$; sin embargo, también se observa DNA genómico, el cual se considera una contaminación ya que la presencia de este podría subestimar la concentración real del RNAm del gen de la endo-PG. En la tabla 5 se resumen los resultados de la cuantificación del RNA extraído en los diferentes tiempos de crecimiento así como los valores de relación de absorbancia a 260/280. 


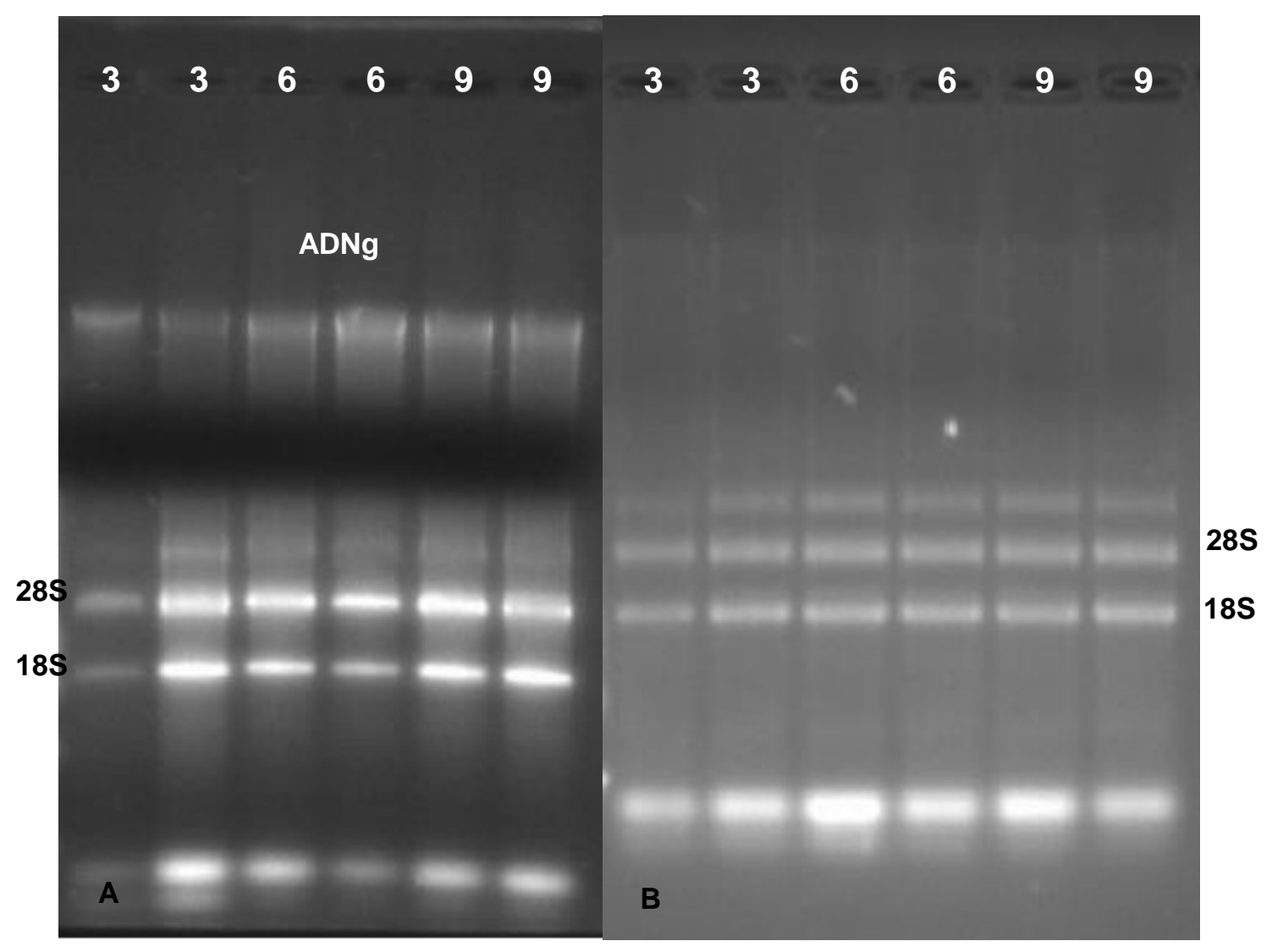

Figura 10. Electroforesis de RNA total obtenido a partir del crecimiento de K. marxianus CDBBL-278 en condiciones aerobias (A) y anaerobias (B). Los carriles marcados con el número 3,6 y 9 representan los tiempos (en horas) de crecimiento a partir de los cuales se obtuvieron las muestras.

En la Figura 10B se muestra el gel de agarosa de la extracción de RNA obtenido a partir del crecimiento en condiciones anaerobias. Se observa en el gel las bandas representativas del RNA ribosomal $28 S$ y $18 S$ así como la presencia de DNA genómico que como se mencionó anteriormente se considera un contaminante. En la tabla 6 se resumen los resultados de la concentración de RNA obtenido en los diferentes tiempos de crecimiento así como la pureza del mismo reportado como 
la relación de absorbancia de 260/280. Dicha relación debe ser de al menos 1.9 ya que de lo contrario existe la posibilidad de tener compuestos que pueden inhibir la reacción.

Tabla 5. Concentración y pureza del RNA extraído a partir del crecimiento aerobio

\begin{tabular}{|c|c|c|}
\hline $\begin{array}{c}\text { Muestra } \\
\text { (tiempo de } \\
\text { crecimiento en } \mathbf{h})\end{array}$ & $\begin{array}{c}\text { Concentración } \\
\text { RNA }(\mathbf{n g} / \boldsymbol{\mu L})\end{array}$ & $\begin{array}{l}\text { Pureza de RNA } \\
\text { relación de } \\
\text { absorbancia } \\
\text { 260/280) }\end{array}$ \\
\hline 3 & 15.2 & 1.94 \\
\hline 6 & 55.8 & 2.13 \\
\hline 9 & 52.8 & 2.10 \\
\hline
\end{tabular}

Tabla 6. Concentración y pureza del RNA extraído a partir del crecimiento anaerobio.

\begin{tabular}{|c|c|c|}
\hline $\begin{array}{c}\text { Muestra } \\
\text { (tiempo de } \\
\text { crecimiento en } \mathrm{h})\end{array}$ & $\begin{array}{c}\text { Concentración } \\
\text { RNA (ng/ } \boldsymbol{\mu L})\end{array}$ & $\begin{array}{c}\text { Pureza de RNA relación } \\
\text { de absorbancia 260/280 }\end{array}$ \\
\hline 3 & 15.7 & 1.98 \\
\hline 6 & 44.5 & 2.12 \\
\hline 9 & 58.5 & 2.14 \\
\hline
\end{tabular}

7.5 Tratamiento con DNAsa a las muestras de RNA 
Con la finalidad de eliminar el DNA genómico (gDNA) que se extrajo junto con el RNA se llevó a cabo un tratamiento con la enzima DNAsa libre de RNAsa de la marca Promega.

Se tomaron alícuotas de RNA para obtener una concentración de 100 ng. Se realizó una modificación al protocolo recomendado por el proveedor ya que se añadió el doble de cada uno de los reactivos y se incubó durante $1 \mathrm{~h}$ a $37^{\circ} \mathrm{C}$. Con la finalidad de asegurar la eliminación total del gDNA presente en las muestras de RNA extraído. Después del tratamiento con la enzima DNAsa se realizó un PCR punto final para corroborar que no había amplificación en las muestras de RNA. Una vez que se aseguró la no amplificación por medio de PCR de las muestras de RNA se procedió a realizar la reacción de transcripción inversa para pasar el RNA a DNA complementario (cDNA) y con este último realizar el PCR tiempo real o cuantitativo (RT-q-PCR).

En la Figura 11 se observa el gel de agarosa de los productos de PCR realizados a las muestras de RNA después del tratamiento de DNAsa. Como se esperaba en estas muestras (carriles 1 y 2 ) no hay amplificación ya que el molde para el PCR es DNA y en estas muestras existe sólo RNA. En los carriles 3 y 4 se observa la amplificación de una banda después de la transcripción inversa (para obtener cDNA a partir de RNA). Estos resultados corroboran que el tratamiento con DNAsa utilizado para la eliminación de gDNA fue el adecuado, por lo que se utilizó este método para tratar el resto de las muestras de las fermentaciones. En caso de que hubiera aparecido una banda de amplificación después del tratamiento con DNAsa 
del RNA extraído, se tendría que repetir el tratamiento con DNAsa hasta que no se obtuviera producto de amplificación.

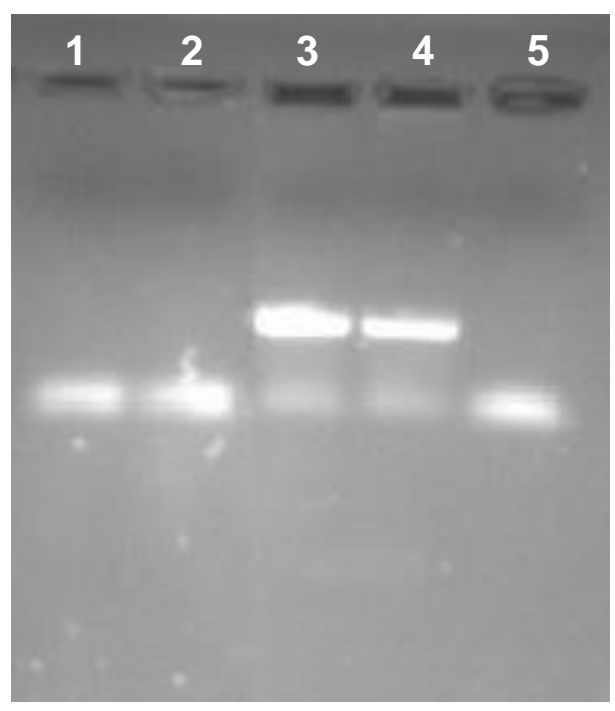

Figura 11. Electroforesis del producto de PCR obtenido a partir de RNA extraído de la levadura en crecimiento anaerobio después del tratamiento con DNAsa. Carril 1 y 2: amplificación de RNA después de tratamiento de DNAsa; carril 3 y 4: amplificación de cDNA obtenido a partir de las muestras de los carriles 1 y 2; Carril 5: Control negativo de reactivos.

\subsection{Diseño de cebadores para el PCR cuantitativo}

Una vez que se comprobó la presencia del gen EPG en la cepa de K. marxianus CDBBL-278, se llevó a cabo el diseño de los cebadores que se utilizaron en el PCR cuantitativo.

Se utilizó el software proporcionado en la página del IDT (https://www.idtdna.com) siguiendo las instrucciones especificadas para obtener diferentes combinaciones 
de cebadores y al final se seleccionó un juego de cebadores tomando en cuenta los criterios de selección mencionados en la metodología.

7.6.1 Verificación del diseño de los cebadores y estandarización de las temperaturas de hibridación para el PCR tiempo real

Después del diseño de los cebadores, éstos se probaron realizando un PCR punto final con gradiente de temperatura para encontrar la temperatura de hibridación que no provocara la formación de dímeros de cebadores u otras estructuras secundarias entre ellos. Posteriormente se realizó una electroforesis en gel de agarosa al 2\% utilizando buffer TBE como solución de corrida; en dicho gel se verificó la presencia de una sola banda con el tamaño de amplicón esperado de acuerdo al diseño del cebador. En la Figura 12 se muestra el gel de agarosa correspondiente a la amplificación del gen de la endo-PG. 


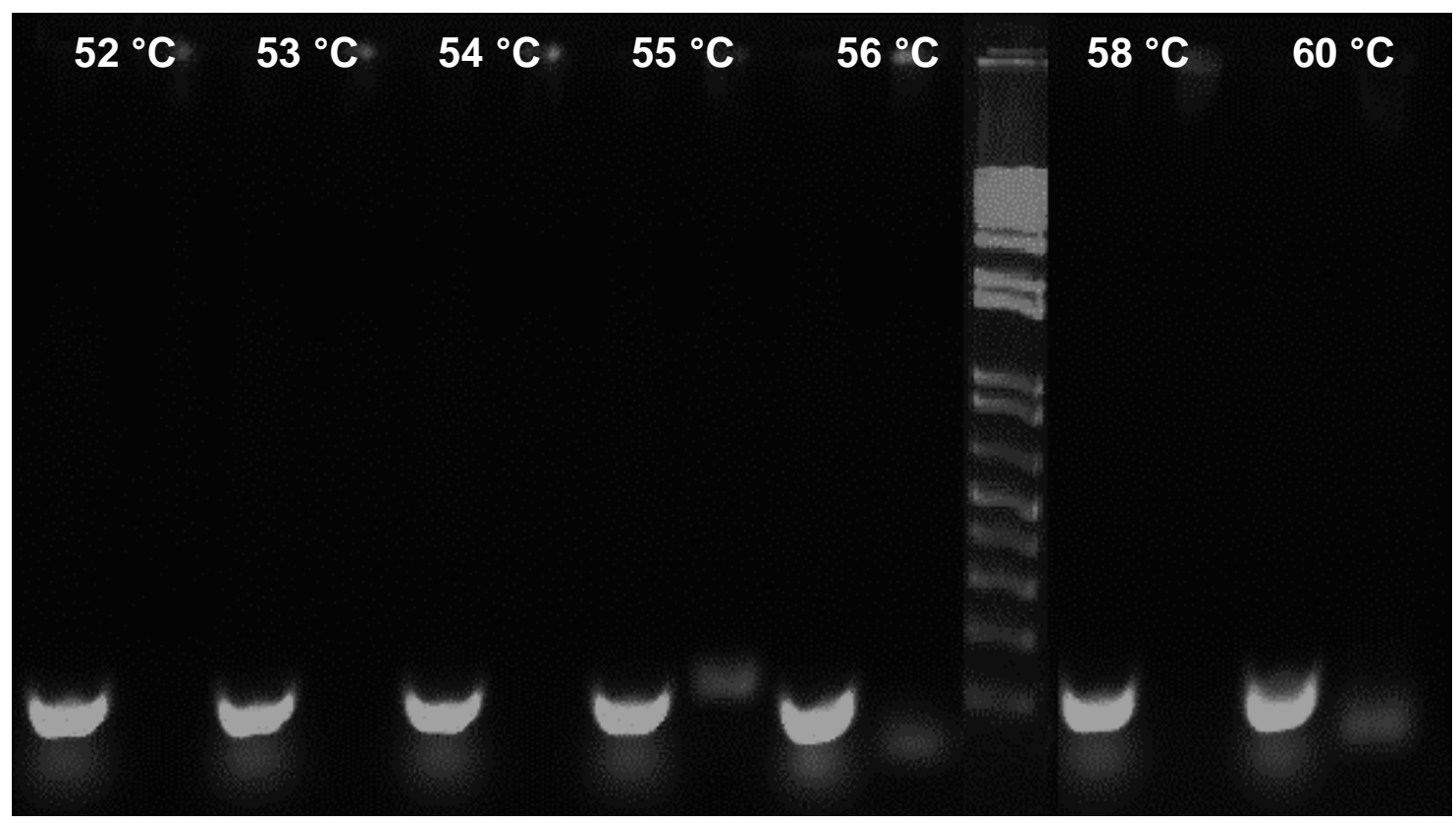

Figura 12. Electroforesis del producto de PCR con gradiente de temperatura de 52 a 60 ${ }^{\circ} \mathrm{C}$ para la amplificación del gen EPG. M: Marcador de talla molecular.

Se observa que en las temperaturas de $52,53,54$ y $58{ }^{\circ} \mathrm{C}$ se obtiene la amplificación de una sola banda de alrededor de 150 pares de bases en las muestras positivas y la ausencia de amplificación en los controles negativos. Por otra parte, se observa también la amplificación de una sola banda en las muestras positivas de las temperaturas de 55,56 y $60^{\circ} \mathrm{C}$; sin embargo en los controles negativos de estas temperaturas se observa una banda la cuál puede deberse a la formación de dímeros de cebadores, o alguna otra estructura secundaria lo cual significa que estas temperaturas de hibridación no son adecuadas para llevar a cabo las reacciones de amplificación.

La Figura 13 muestra el gel de agarosa de los productos de PCR obtenidos con el gradiente de temperatura de hibridación de 53 a $63{ }^{\circ} \mathrm{C}$ para verificar la 
amplificación del gen 18S. Bajo estas condiciones se obtuvo la amplificación de una sola banda correspondiente aproximadamente a 123 pares de bases, lo cual significa que los cebadores diseñados son específicos para amplificar el fragmento del gen $18 \mathrm{~S}$ esperado. Se observa también que en el intervalo de temperatura de 53 a $63^{\circ} \mathrm{C}$ no hay formación de estructuras secundarias, ya que en los controles negativos no hay presencia de bandas amplificadas. Por lo que la amplificación del gen $18 \mathrm{~S}$ con los cebadores aquí especificados es factible en el intervalo de temperatura de 53 a $63^{\circ} \mathrm{C}$. 

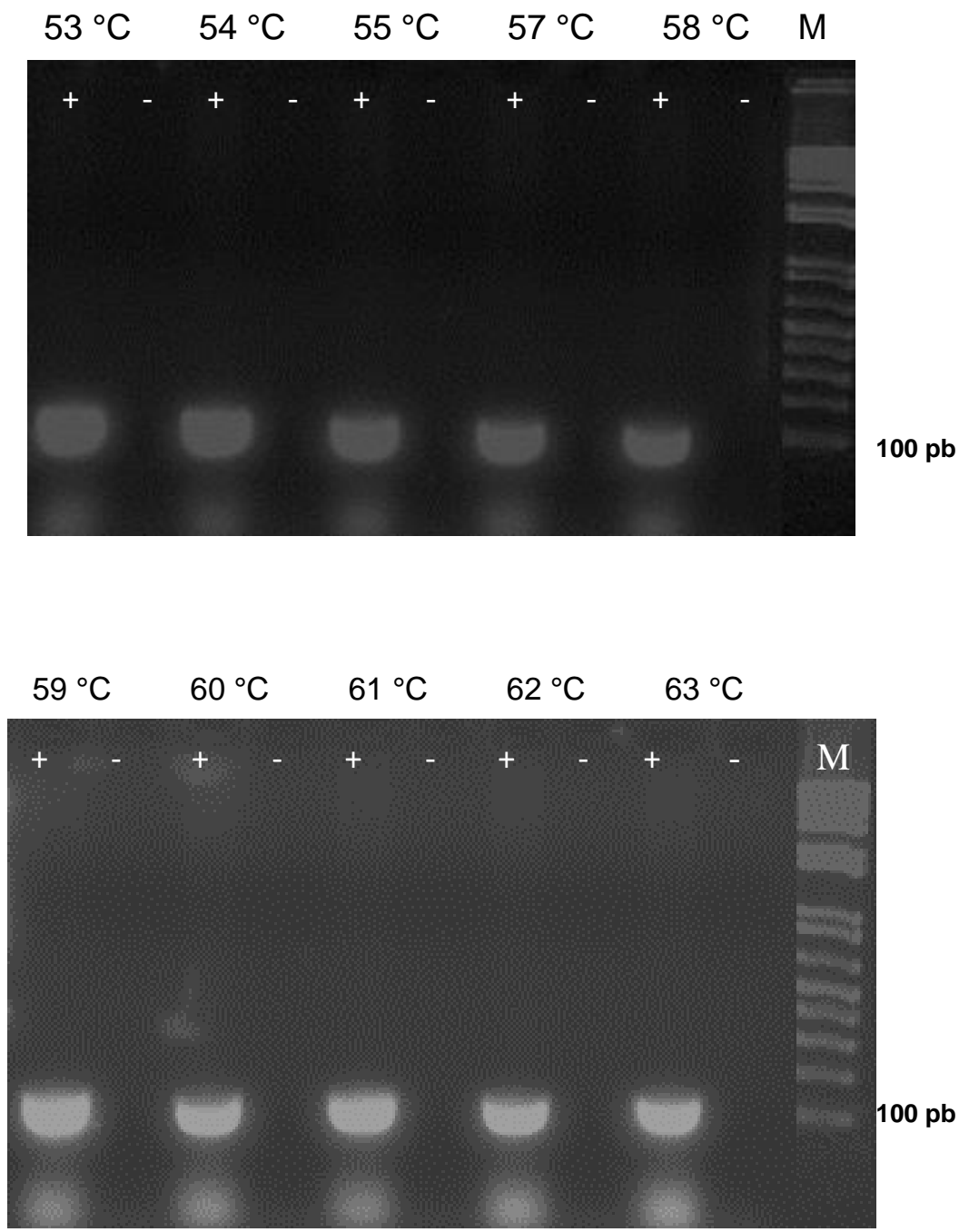

Figura 13. Electroforesis del producto de PCR con gradiente de temperatura de 53 a 63 ${ }^{\circ} \mathrm{C}$ para la amplificación del gen $18 S$

Finalmente se realizó un PCR con gradiente de temperatura de hibridación de 53 a $57.2^{\circ} \mathrm{C}$ para verificar la amplificación del gen $A C T 1$. Se puede observar en la Figura 14, que en el intervalo de temperatura experimentado se obtiene la amplificación de una sola banda correspondiente aproximadamente a 125 pares de bases lo cual significa que los cebadores diseñados son específicos para amplificar el fragmento del gen $A C T 1$ esperado. Se observa también que en el 
intervalo de temperatura de 53 a $57.2{ }^{\circ} \mathrm{C}$ no hay formación de estructuras secundarias, ya que en los controles negativos no hay presencia de bandas amplificadas. Por lo que la amplificación del gen $A C T 1$ con los cebadores aquí especificados es factible en el intervalo de temperatura de 53 a $57.2^{\circ} \mathrm{C}$.

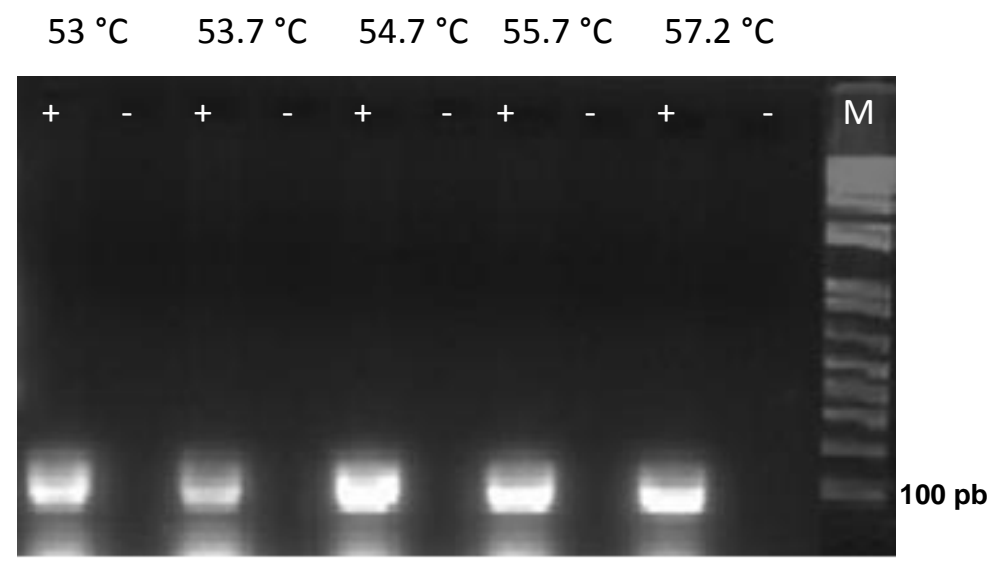

Figura 14. Electroforesis del producto de PCR con gradiente de temperatura de 53 a 57.2 ${ }^{\circ} \mathrm{C}$ para la amplificación del gen $A C T 1$

7.6.2 Verificación de la especificidad y amplificación por PCR tiempo real de las sondas

Una vez que se verificó que los cebadores diseñados amplificaban una sola banda y después de encontrar la temperatura en la cual no se observa la formación de estructuras secundarias se procedió a examinar las sondas.

Para tal efecto se realizaron reacciones de PCR tiempo real para cada uno de los genes con sus respectivos juegos de sondas y cebadores. Las reacciones de PCR se realizaron de acuerdo a lo descrito en el punto 5.1.2 descrito en la metodología. 
En la Figura 15 se observa el gráfico de PCR tiempo real para los ensayos del gen EPG y 18S. Se observa que para los dos genes hay un aumento en la fluorescencia, este aumento en la señal de fluorescencia es un indicio de que las sondas están bien diseñadas.

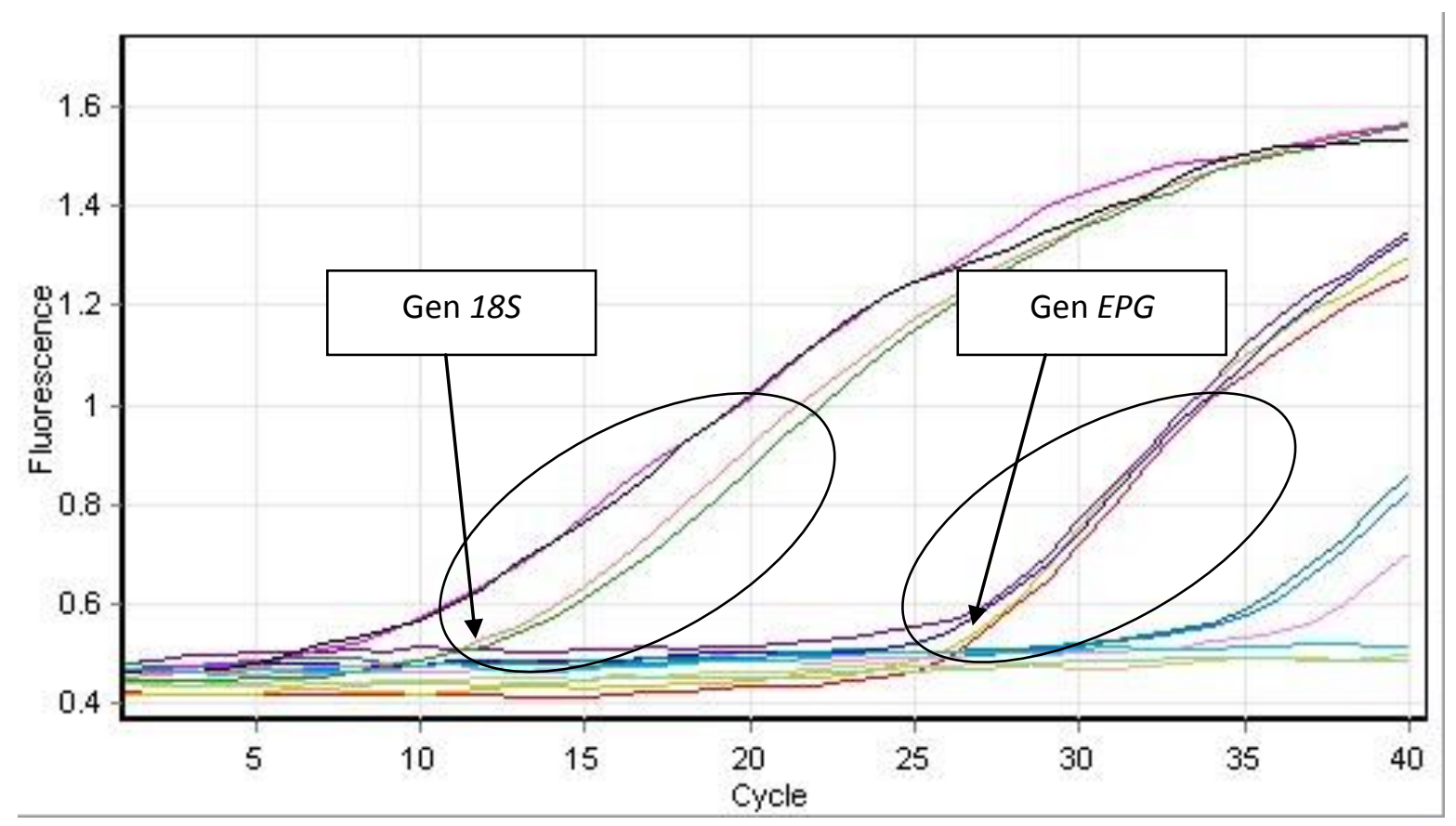

Figura 15. Curvas de amplificación por PCR tiempo real de los genes $18 S$ (izquierda) y EPG (derecha) para verificación de especificidad de los cebadores y sondas diseñados.

En la Figura 16 se observa el gráfico de amplificación por PCR tiempo real para los ensayos del gen ACT1. Se observa que hay un aumento en la fluorescencia durante la amplificación de este gen, este aumento en la señal de fluorescencia es un indicio de que la sonda fue bien diseñada. 


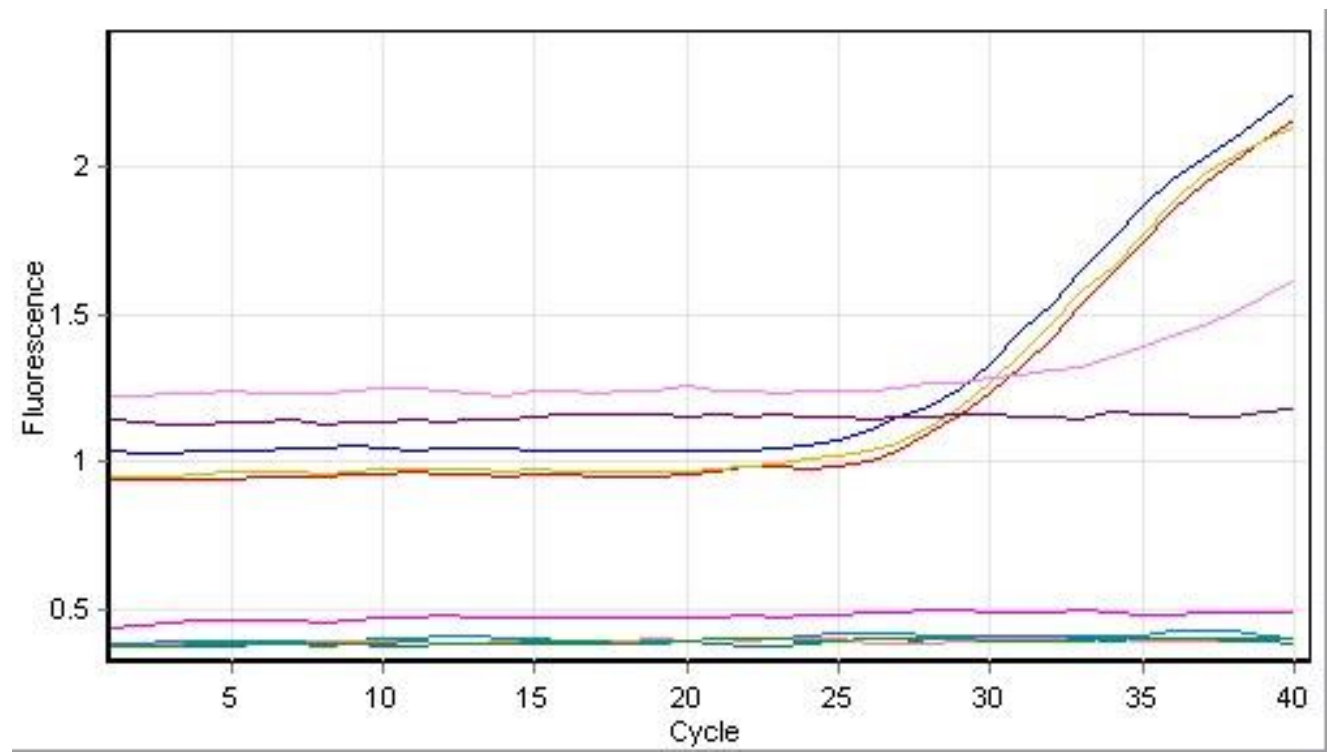

Figura 16. Curvas de amplificación por PCR tiempo real del gen ACT1 para verificación de especificidad de los cebadores y sondas diseñados

Una vez que se confirmó que el diseño de los cebadores para cada gen amplificara el tamaño de los fragmentos esperados, se obtuviera una sola banda como producto de la amplificación y la ausencia de formación de estructuras secundarias; y para el caso de las sondas que se observara el aumento en la señal de fluorescencia se procedió a trabajar en la estandarización de las condiciones de PCR tiempo real para obtener la eficiencia de amplificación para los cebadores. 
7.7 Determinación de la eficiencia de amplificación de los genes EPG, $18 S$ y ACT1

Debido a que se llevó a cabo una cuantificación relativa de la expresión del gen de la endo-PG con respecto a la expresión de genes normalizadores, fue necesario determinar la eficiencia de amplificación de cada uno de los genes en una condición de crecimiento para posteriormente realizar los cálculos de los niveles de expresión.

Para determinar la eficiencia de amplificación se decidió utilizar una sola temperatura de hibridación para los tres genes. Se seleccionó la temperatura de $54{ }^{\circ} \mathrm{C}$ ya que cuando se realizaron los gradientes de temperatura se observó que bajo estas condiciones no hay formación de estructuras secundarias en ninguno de los casos y se obtiene también un solo producto de amplificación. Para el PCR tiempo real se utilizó el cDNA obtenido de la fermentación aerobia. Las diluciones y reacciones de PCR se llevaron a cabo de acuerdo a lo descrito en el punto 6.1 de la metodología. Se amplificaron los genes $A C T 1,18 S$ y EPG.

Los resultados obtenidos para el gen $A C T 1$ se muestran en la Figura 17. En el panel A se observan las curvas de amplificación, los duplicados para cada dilución y el control negativo de reactivos. En el panel B se encuentra el valor de la eficiencia de amplificación obtenido para este par de cebadores siendo el valor de 100\%. Los valores de Ct obtenidos para cada dilución se muestran en el Anexo 1. Cabe señalar que se obtiene un buen coeficiente de correlación (0.998) para los valores de curva de actina y una eficiencia de amplificación de 101\%. Las eficiencias derivadas de las series de diluciones no son valores exactos sino son 
estimadas con una incertidumbre. Esto explica las eficiencias aparentemente imposibles mayores a 100\%, lo que sugiere también que valores de eficiencia de 94\% no son realmente diferentes de valores de 99\% (Brookman- Amissah et al. 2015).

Panel A

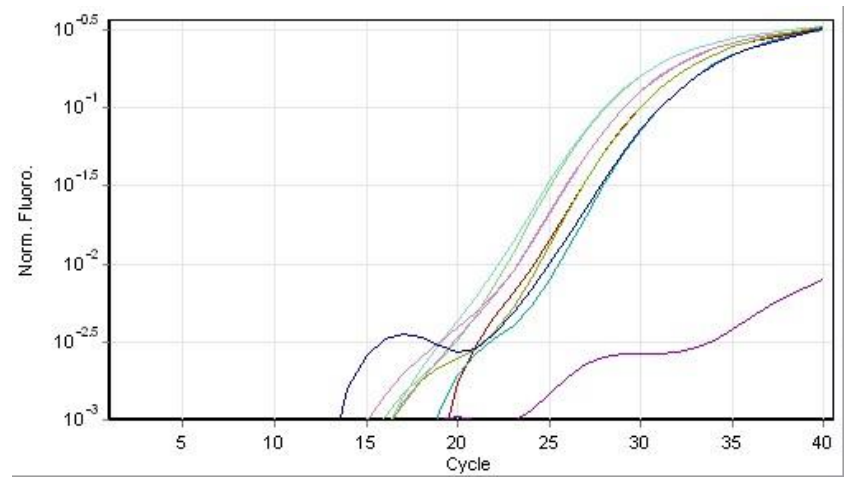

Panel B

\begin{tabular}{|l|l|}
\hline Eficiencia de la & $1.01338\left(^{*}=\right.$ \\
reacción $\left(^{*}\right)$ & $\left.10^{\wedge}(-1 / \mathrm{m})-1\right)$ \\
\hline M (pendiente) & -3.29028 \\
\hline $\begin{array}{l}\text { B (ordenada al } \\
\text { origen) }\end{array}$ & 32.66217 \\
\hline Valor $\mathrm{R}$ & 0.99916 \\
\hline Valor $\mathrm{R}^{\wedge} 2$ & 0.99832 \\
\hline
\end{tabular}

Figura 17. Curvas de amplificación por PCR tiempo real y resultados de la eficiencia de amplificación obtenidos para el gen ACT1.

Para el caso de la eficiencia de amplificación del gen EPG los resultados se observan en la Figura 18. Se aprecia en el panel A, el duplicado para cada dilución de las curvas de amplificación para el gen EPG. En el panel B se presenta la eficiencia de amplificación. Los valores de la concentración de las diluciones y los 
valores de CT obtenidos para cada dilución se presentan en el Anexo 1. En este caso se obtuvo un valor de eficiencia de amplificación de 98\%.

Panel A

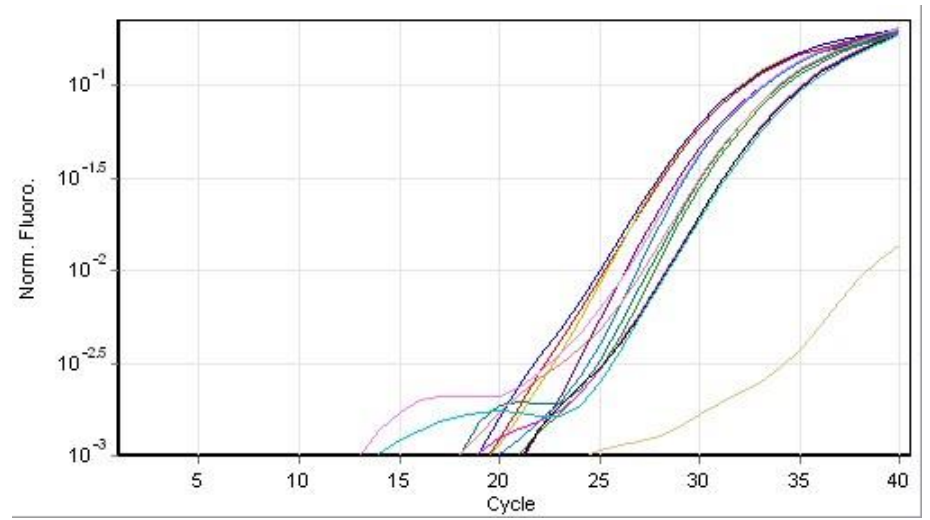

Panel B

\begin{tabular}{|l|l|}
\hline $\begin{array}{l}\text { Eficiencia } \\
\text { de la reacción }\left(^{*}\right)\end{array}$ & $\begin{array}{l}0.98853\left(^{*}=\right. \\
\left.10^{\wedge}(-1 / \mathrm{m})-1\right)\end{array}$ \\
\hline M (pendiente) & -3.34972 \\
\hline $\begin{array}{l}\text { B (ordenada al } \\
\text { origen) }\end{array}$ & 36.96344 \\
\hline Valor R & 0.99485 \\
\hline Valor $\mathrm{R}^{\wedge} 2$ & 0.98972 \\
\hline
\end{tabular}

Figura 18. Curvas de amplificación por PCR tiempo real y resultados de la eficiencia de amplificación obtenidos para el gen EPG

Los resultados de eficiencia de amplificación para el gen $18 \mathrm{~S}$ se muestran en la Figura 19. Se obtuvo una eficiencia de amplificación de 99\%. 
Panel A

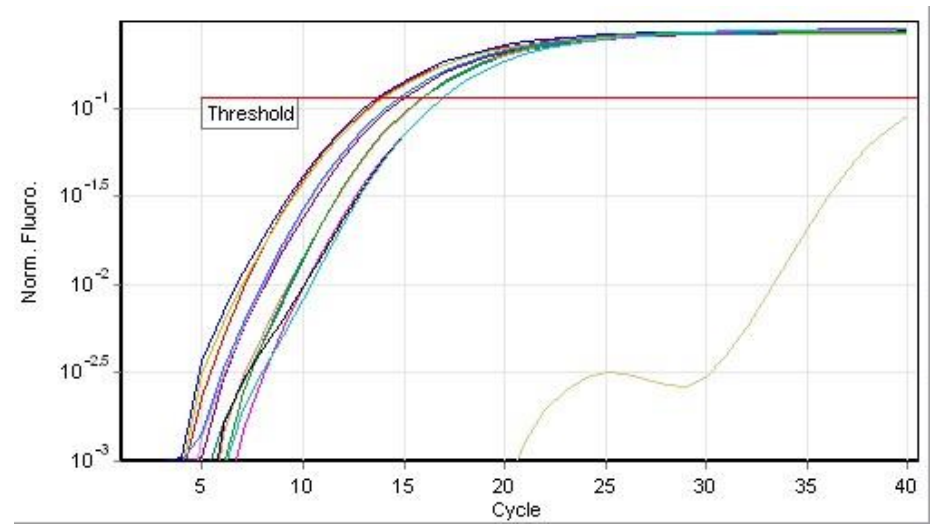

\begin{tabular}{|l|l|}
\hline $\begin{array}{l}\text { Eficiencia de la } \\
\text { reacción }\left(^{*}\right)\end{array}$ & $\begin{array}{l}0.99025\left(^{*}=10^{\wedge}(-\right. \\
1 / \mathrm{m})-1)\end{array}$ \\
\hline $\mathrm{M}$ (pendiente) & -3.34551 \\
\hline $\begin{array}{l}\mathrm{B} \text { (ordenada al } \\
\text { origen) }\end{array}$ & 18.20439 \\
\hline Valor $\mathrm{R}$ & 0.997 \\
\hline Valor $\mathrm{R}^{\wedge} 2$ & 0.994 \\
\hline
\end{tabular}

Figura 19 Curvas de amplificación por PCR tiempo real y resultados de la eficiencia de amplificación obtenidos para el gen $18 S$

7.8 Cuantificación del gen EPG durante el crecimiento de $K$. marxianus en condiciones de oxígeno controladas

Finalmente se realizó un experimento en el cual se amplificó el gen EPG a partir muestras de cDNA obtenidas durante el crecimiento aerobio y anaerobio. Además de estas muestras también se realizó el PCR de controles negativos de reactivos. Las curvas de amplificación para las muestras obtenidas durante el crecimiento en condiciones anaerobias se muestran en la Figura 20 y en la Figura 21 para el caso del crecimiento en condiciones aerobias. Los Valores de Ct obtenidos en la PCR se muestran en el Anexo 2 para cada una de las diferentes muestras. 


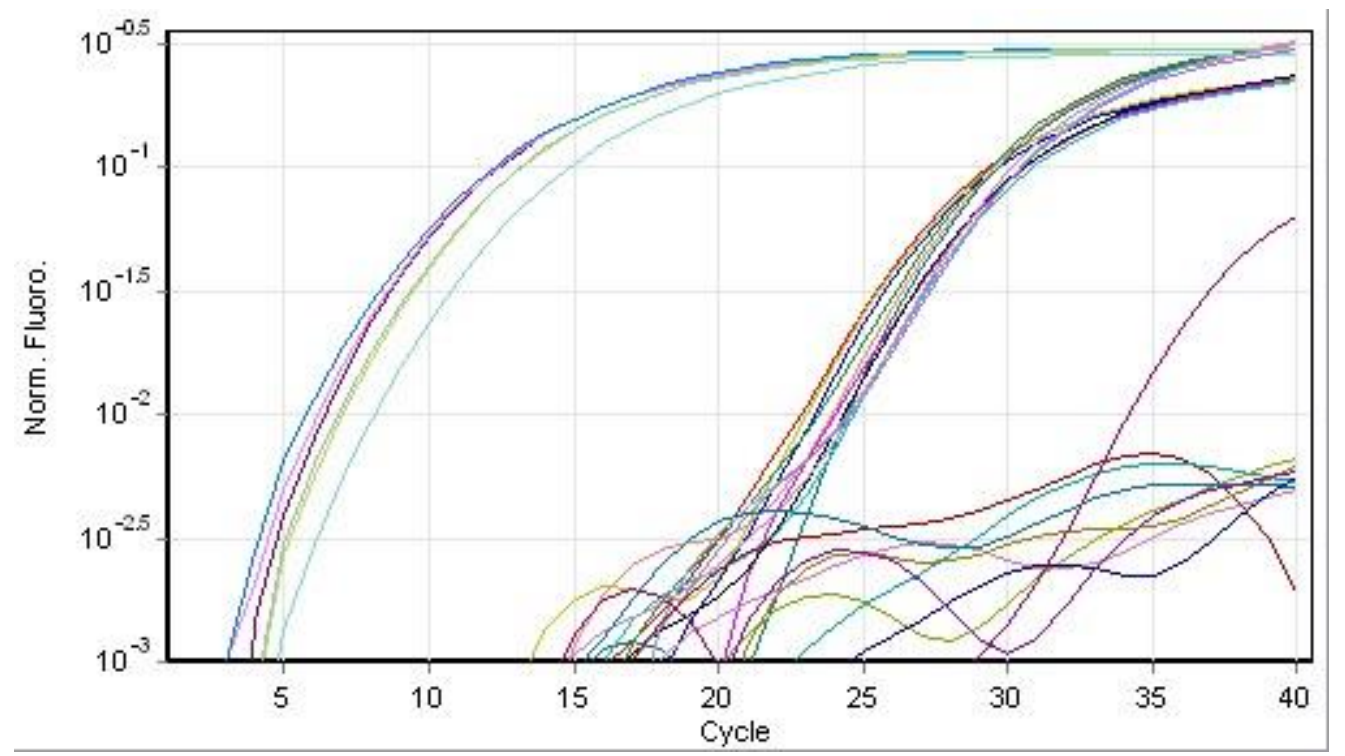

Figura 20. Curvas de amplificación por PCR tiempo real para la cuantificación de la expresión del gen de la endo-PG en condiciones anaerobias de crecimiento.

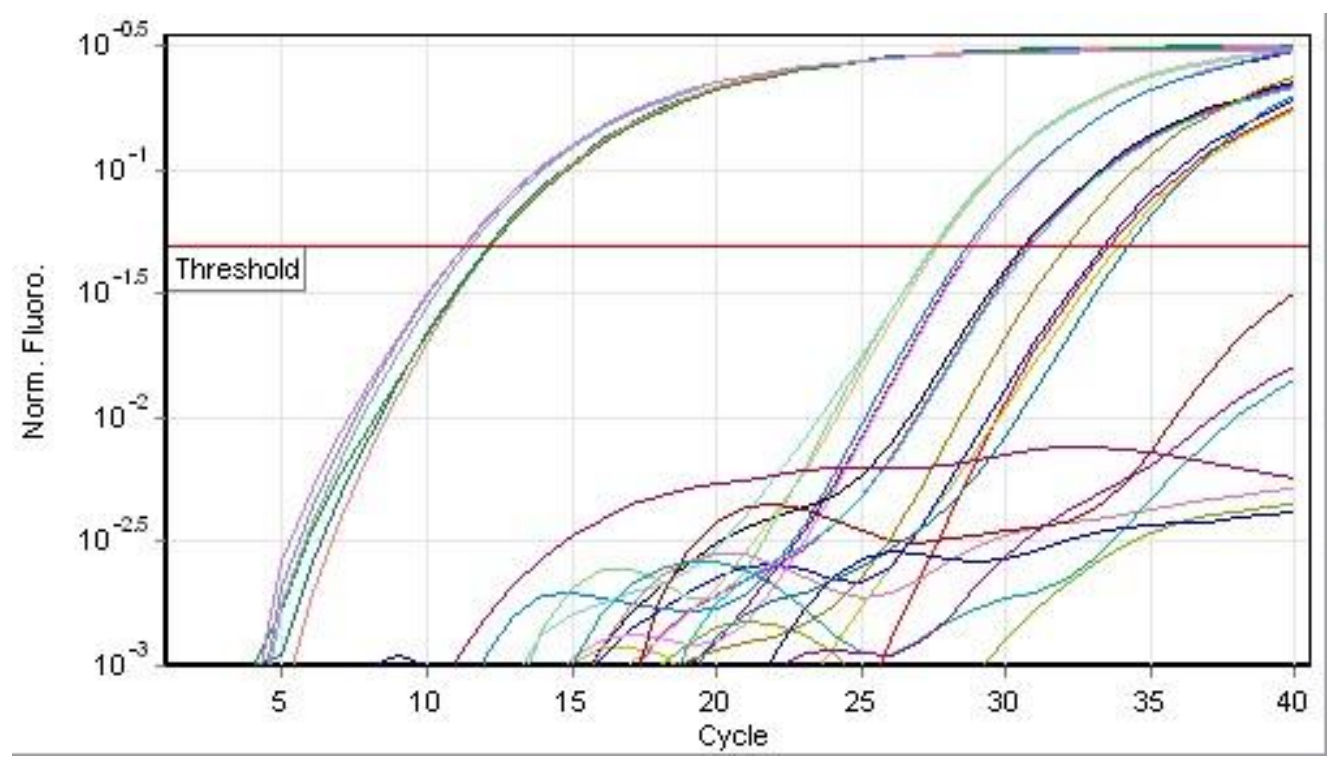

Figura 21. Curvas de amplificación por PCR tiempo real para la cuantificación de la expresión del gen de la endo-PG en condiciones aerobias de crecimiento 
El promedio del valor de Ct para el gen EPG obtenido a las 9 horas de crecimiento bajo condiciones anaerobias fue de $27.94 \pm 0.87$, mientras que para el crecimiento aerobio en el mismo tiempo fue de 32.69 \pm 1.34 (Figura 22); ya que el valor de $\mathrm{Ct}$ es inversamente proporcional al valor inicial de cDNA presente en las muestras, se observa que se obtuvo un mayor nivel de expresión del gen EPG bajo condiciones anaerobias de crecimiento. Estos resultados confirman que disminuyendo la saturación de OD en el medio de crecimiento se favorece la inducción de la expresión del gen, resultando un incremento en la actividad de la endo-PG. Este hallazgo es muy importante ya que actualmente no hay referencias donde se estudien enzimas pectinasas que se regulan bajo diferentes concentraciones de oxígeno, adicionalmente es preciso incidir que tampoco hay documentación donde se haya analizado la correlación de la actividad de estas enzimas con los niveles de expresión de los genes. 


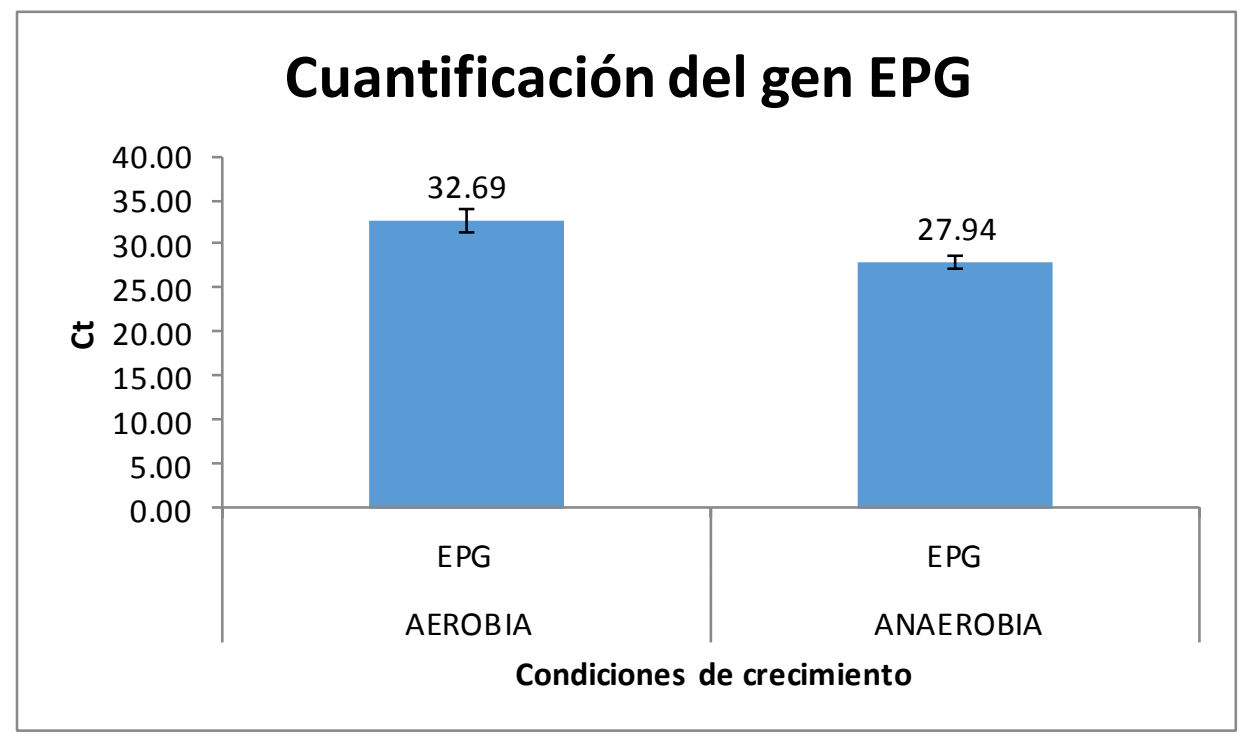

Figura 22. Valores de Ct obtenidos bajo condiciones aerobias y anaerobias de crecimiento para K. marxianus

En la Figura 23 se muestra el gráfico con los valores de Ct para la cuantificación del gen EPG y los genes utilizados como normalizadores $18 S$ y $A C T 1$. Se observa que hay diferencia significativa entre los valores de Ct obtenidos para el gen EPG en condiciones aerobias y anaerobias de crecimiento, mientras que para los genes normalizadores $A C T 1$ y $18 S$ no hay diferencia significativa en la expresión entre las dos condiciones en estudio; se muestra también un claro aumento en la expresión del gen EPG en condiciones anaerobias de crecimiento comparado con las condicione aerobias, lo cual demuestra una inducción del gen bajo condiciones aerobias. 


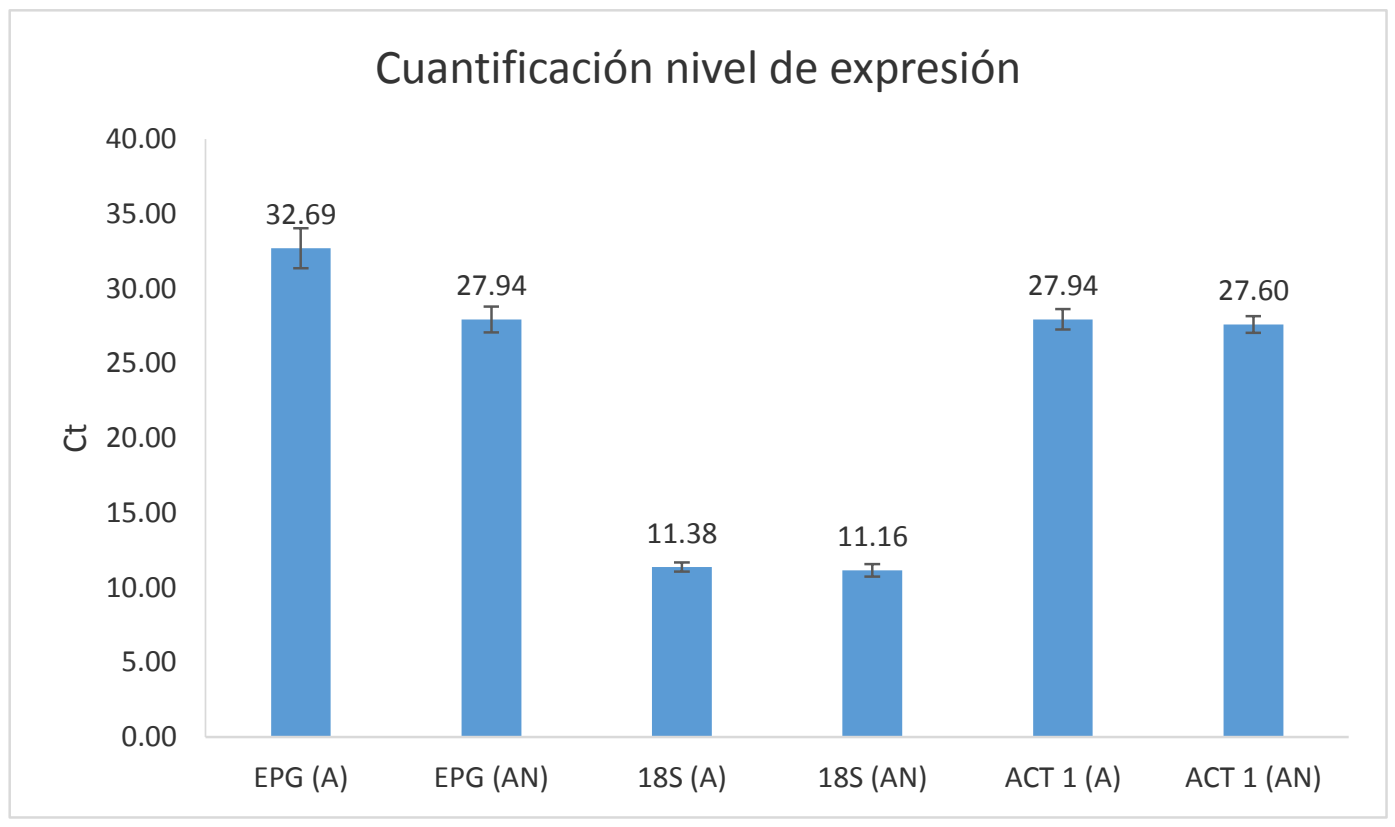

Figura 23. Valores de Ct obtenidos para el gen blanco EPG y los genes normalizadores $18 S$ y $A C T 1$ bajo condiciones aerobias (A) y anaerobias (AN) de crecimiento.

Finalmente se realizó la cuantificación relativa del gen EPG mediante la ecuación reportada por Hellemans et al (2007) (Ecuación 2), mostrando que hay un aumento de 21.19 veces la expresión del gen en condiciones anaerobias comparado con el crecimiento en condiciones aerobias. Estos resultados coinciden con los valores de Ct encontrados donde, se observa una mayor cantidad de cDNA en el crecimiento anaerobio con respecto al aerobio.

Los resultados muestran que la expresión del gen EPG no es constitutiva como lo reportan algunos autores (Wimborne y Rickard et al. 1978, Schwan et al. 1996) si no que es inducida por la concentración de OD en el medio de cultivo. Debido al incremento en la expresión del gen EPG obtenido por $K$. marxianus bajo 
condiciones anaerobias, se podría suponer que su regulación tiene lugar a nivel transcripcional, es decir, podría estar regulado por algunos factores relacionados a con la adaptación de la levadura a condiciones de crecimiento anaerobio o factores de estrés, como sucede con el gen PUG1 de Saccharomyces cerevisiae el cual codifica una endo-PG, En tal caso, se ha estudiado que su expresión es regulada por factores transcripcionales que regulan también genes responsables del fenómeno de floculación y formación de pseudomicelio bajo condiciones de estrés por inanición (Louw et al. 2010).

Se observó también que la actividad específica de la endo-PG se incrementó 5 veces bajo condiciones anaerobias comparado con el crecimiento aerobio, lo cual se puede correlacionar con el aumento en el nivel de la expresión del gen observado. El hecho de que el aumento en el nivel de expresión del gen sea mayor que el incremento en la actividad enzimática bajo condiciones anaerobias, podría deberse a control de la traducción, ya que no todo el RNAm que se produce es traducido a proteína (Shah et al. 2013), o a otros mecanismos de control de la expresión génica como la estabilidad del ARNm, cuya vida media se ve afectada por la presencia de otras moléculas reguladoras las cuales se encargan de degradar al ARNm en el citosol o a modificaciones post-traduccionales que pueden conducir a un cambio en su actividad (Reece et al. 2011) 


\section{CONCLUSIONES}

El gen de endo-PG de K. marxianus CDBBL-278 es una variante distinta a las otras secuencias reportadas para esta misma enzima (EPG1 y EPG1 alelo EPG12)

El análisis filogenético reveló una clara separación entre las endo-PG del género Saccharomyces y las del género Kluyveromyces, y entre las endo-PG del género Kluyveromyces se observa una diferencia entre las endo-PG de K. marxianus que contienen el aminoácido adicional valina (cepas DMKU3-1042, CECT 1043 y CDBBL-278) y la cepa que no tiene este aminoácido (cepa BMKY-719).

Se confirma la hipótesis de que el nivel de oxígeno disuelto en el medio de cultivo repercute en el nivel de expresión del gen de la endo-PG al observar una mayor expresión del gen en condiciones de crecimiento anaerobio comparado con el aerobio.

Las condiciones de crecimiento anaerobio promovieron la actividad de la endo-PG así como la expresión del gen EPG estos resultados resaltan que el aumento en la producción de la endo-PG bajo condiciones de cultivo anaerobio es una consecuencia de la regulación del gen EPG debido a la saturación del OD en el medio de cultivo. 


\section{PERSPECTIVAS}

La expresión del gen EPG es una cuestión compleja, por una parte, se ha demostrado que se reprime por el oxígeno, pero se ha reportado que es inducida por la pectina en condiciones aerobias (García Garibay et al. 1987); por lo que vale la pena estudiar los diversos aspectos involucrados en la represión-activación de éste gen, que parece ser inusual.

Algunas de las perspectivas que se derivan de este estudio se circunscriben a la cuantificación del gen de la endo-PG agregando como inductor pectina al medio de crecimiento en condiciones aerobias y comparar la expresión del gen en estas condiciones con las de crecimiento anaerobio, con la finalidad de evaluar si los inductores aumentan en la misma proporción la expresión y actividad de la enzima.

Por otra parte se podría realizar un estudio utilizando la técnica de microarreglos, para analizar los genes que se activan adicionando pectina como inductor a un medio en crecimiento aerobio para $K$. marxianus, y otro estudio para determinar los genes que se activan bajo condiciones de crecimiento anaerobio; con la finalidad de elucidar si el gen de la endo-PG se regula de la misma forma con dos inductores diferentes. 


\section{BIBLIOGRAFIA}

- Accinelli E, Brida J.G. (2006) Crecimiento económico óptimo y crecimiento poblacional: Una version mejorada del modelo de Ramsey. Papeles de población. 12(47):227-241

- Alimardani-Theuil P, Gainvors-Claisse A, Duchiron F. (2011). Yeasts: An attractive source of pectinases-From gene expression to potential applications: A review. Process Biochemistry. 46: 1525-1537

- Blanco P., Sieiro C., Reboredo NM, Villa TG. (1998). Cloning, molecular characterization, and expression of an endo-polygalacturonase- enconding gene fron Saccharomyces cerevisiae IM1-8b. FEMS Microbiology Letters 164:249-255

- Blanco P., Sieiro C., G. Villa T. (1999) Production of pectic enzymes in yeast. FEMS Microbiology Letters.175:1-9

- Bleve G, Rizzotti L, Dellaglio F, Torriani S. (2003) Development of reverse Transcription (RT)-PCR and real time RT-PCR assays for rapid detection and quantification of viable yeast and molds contaminating yogurts and pasteurized food products. Applied and Environmental Microbiology. 69: 4116-4122

- Brookman-Amissah Nicola, Packer Hans, Prediger Ellen, Sabel Jaime (Editores). (2015). qPCR Application Guide Experimental Overview, Protocol, Troubleshooting. IDT technology. 4a edicion. www.idtdna.com/pages/landing/qpcr/guide. Última revision 26 de Junio de 2017

- Cruz Guerrero A. E (1995). Regulación de la síntesis y excreción de enzimas extracelulares de Kluyveromyces marxianus. Tesis de Maestría. Universidad Autónoma Metropolitana (UAM) 72 pag. 
- Cruz Guerrero A. E., García Peña I., Barzana E., García Garibay M., Gómez Ruíz L. (1995). Kluyveromyces marxianus CDBB-L-278 a wild inulinase hyperproducing strain. Journal of Fermentation and Bioengineering. 80: 159-163

- Cruz Guerrero. A. E., Bárzana E., García G. M., Gómez R L. (1999). Dissolved oxygen threshold for the repression of endo-polygalacturonase production by Kluyveromyces marxianus. Process Biochemistry 34:621-624

- Darriba D, Taboada GL, Doallo R, et al. (2011). ProtTest 3: fast selection of best-fit models of protein evolution. Bioinformatics. 27:1164-1165

- Espinoza P, Bárzana E, García-Garibay M, Gómez-Ruiz L. (1992). Evaluation of Kluyveromyces marxianus for the production of lactase simultaneously to pectinase or inulinase. Biotechnology Letters. 14: 10531058

- Federici F. (1985) Production, purification and partial characterization of an endopolygalacturonase from Cryptococcus albidus var. albidus. Antonie van Leeuwenhoek. 51 (2) 139-150.

- García Garibay. M., Gómez Ruíz. L., y Bárzana E. (1987) Studies on the simultaneous production of single cell protein and poligalacturonase from Kluyveromyces fragilis. Biotechnology Letters. 9 (6): 411-416

- Gómez-Ruiz L, García-Garibay M, Bárzana E. (1988). Utilization of endopolygalacturonase from Kluyveromyces fragilis in the clarification of apple juice. Journal of Food Science. 53: 1236-1237, 1240

- Graciano F. G., Heinzle E., Wittmann C., K. Gombert A. (2008). The yeast Kluyveromyces marxianus and its biotechnological potential. Applied Microbiology and Biotechnology. 79:339-354 
- Guindon S, Gascuel O. (2003). A simple, fast, and accurate algorithm to estimate large phylogenies by maximum likelihood. Systematic Biology. 52: 696-704

- Heid A. C., Stevens Junko., Livak Kenneth J., Williams P Mickey. (1996). Real time quantitative PCR. Genome Methods. 6: 986-994

- Hellemans J, Mortier G, De Paepe A, Speleman F, Vandesompele J. (2007). QBase relative quantification framework and software for management and automated analysis of real-time quantitative PCR data. Genome Biology. 8: $\mathrm{R} 19$

- Inokuma K, Ishii J, Hara KY, Mochizuki M, Hasunuma T, Kondo A. (2015). Complete genome sequence of Kluyveromyces marxianus NBRC1777, a nonconventional thermotolerant yeast. Journals ASM org; 3(2) e00389-15

- Kashyap D.R., Vohra P.K., Chopra S. Tewari R. (2001). Applications of pectinases in the commercial sector: A review. Bioresource Technology. 77: 215-227

- Kurtzman C. P., Fell J. W. (Editores). The Yeast, a Taxonomic Study. 4a Edición. Edit Elsevier. 2000 pp 236-238

- Larkin M. A., Blackshields G., Brown N. P., Chenna R., McGettigan P. A., McWilliam H., Valentin F., Wallace I. M., Wilm A., Lopez R Thompson J. D. Gibson T. J. Higgins D. G. (2007). Clustal W and Clustal X version 2.0. Bioinformatics. 23: 2947-2948

- Lertwattanasakul N, Kosaka T, Hosoyama A, Akira Hosoyama, Suzuki Y, Rodrussamee N, Matsutani M, Murata M, Fujimoto N, Suprayogi, Tsuchikane K, Limtong S, Fujita N and Yamad M. (2015) Genetic basis of the highly efficient yeast Kluyveromyces marxianus: complete genome sequence and transcriptome analyses. Biotechnology and Biofuels. 8:47 
- Lim J., Yamasaki Y., Suzuki Y., Ozawa J. (1980) Multiple forms of endopolygalacturonase from Saccharomyces fragilis. Agricultural and Biology Chemistry. 44, 473-480.

- Livak K.J., Schmittgen T.D. (2001). Analysis of relative gene expression data using real time quantitative PCR and the 2(-Delta Delta $C(T)$ method. Methods. 25:402-408

- Louw C., Young R.P., van Rensburg P., Benoit D. (2010). Regulation of endo-polygacturonase activity in Saccharomyces cerevisiae. FEMS Yeast Research. 10:44-57

- Luh B. S., Phaff H .J. (1951) Studies on polygalacturonase of certain yeast. Archives of Biochemistry and Biophysics. 33:212-217

- Luh B. S., Phaf H. J. (1954). Properties of yeast polygalacturonase. Archives of Biochemistry and Biophysics. 48: 23-37

- Mannan MA, Sharma S, Ganesan K. (2009). Total RNA isolation from recalcitrant yeast cells. Analytical Biochemistry. 389(1): 77-79

- Murad H. A, Foda MS. (1992). Production of yeast polygalacturonase on dairy wastes. Bioresource Technology. 41(3): 247-250

- Nelson N. (1944). A photometric adaptation of the Somogyi method for the determination of glucose. Journal of Biological Chemistry. 153 (2):375-380

- Neuhauser C. Matemáticas para Ciencias. Ed Pearson Educación. 2ª edición. 2004. 1016 paginas. Pág. 486

- Pardo C., Lapeña M.A., Gacto M. (1991) Purification and characterization of an extracellular exopolygalacturonase from Geotrichum lactis. Canadian Journal of Microbioogy. 37, 974-977. 
- Pfaffl M.W. (2001). A new mathematical model for relative quantification in real time RT-PCR. Nucleic Acids Research. 29:2002-2007

- Postollec F., Falentin H, Pavan S, Combrisson J, Sohier D (2011). Recent advances in quantitative PCR (qPCR) applications in food microbiology. Food Microbiology. 28: 848-861

- Querci M, Jermini M y Van den Eede G (Editores). Curso de formación sobre: Análisis de la presencia de organismos genéticamente modificados en muestras de alimentos. Sesión 10.2007. http.//mbg.jrc.ec.europa.eu/capacitybuilding/documentation.htm. Última revision 25 de Junio de 2017

- Reece, J. B., Urry, L. A., Cain, M. L., Wasserman, S. A., Minorsky, P. V. y Jackson, R. B. (2011). Campbell biology. 10a ed. San Francisco, CA: Pearson. pp. 372-376

- Rivas R, Vizcaino N, Buey R. M., Mateos P. F., Martínez-Molina E., Velázquez E. (2001). An effective, rapid and simple method for RNA extraction from bacteria and yeast. Journal of Microbiology Methods. 47(1):59-63

- Schwan RF., Rose AH. (1994) Polygalacturonase production by Kluyveromyces marxianus: effect of medium composition. Journal of Applied Bacteriology. 76:62-67

- Schwan RF, Cooper RM, Wheals AE. (1996). Endopolygalacturonase of the yeast Kluyveromyces marxianus is constitutive, highly active on native pectin and is the main extracellular protein. In: Pectins and Pectinases, Proceedings of an International Symposium. (Visser J, Voragen AGJ Eds). Elsevier Science Publisher, New York 
- Shah P, Ding Y, Niemczyk M, Kudla G, Plotkin JB. (2013). Rate-limiting steps in yeast protein translation. Cell 13: 1589-1601

- Sieiro C., F. Sestelo Ana Belen., G. Villa Tomas (2009). Cloning, characterization, and functional analysis of the EPG1-2 gene: A new allele coding for an endopolygalacturonase in Kluyveromyces marxianus. Journal of Agricultural and Food Chemistry. 57:8921-8926

- Siekstele R., Bartkeviciute D. Sasnauskas K. (1999). Cloning, targeted disruption and heterologous expression of the Kluyveromyces marxianus endopolygalacturonase gene (EPG1). Yeast. 15(4):311-322

- Silveira W. B., Diniz R. H. S., Cerdán M. E., González-Siso M I., Robson de A Souza R, Vidigal P., Brustolini J. B. O, de Almeida Prata E R. B., Medeiros C. A, Paiva C L, Nascimento M, Ferreira G. E., dos Santos C V, Bragança S. C. R, Fernandes R T A. Colombo L T, Passos L F M. (2014) Genomic Sequence of the yeast Kluyveromyces marxianus CCT 7735 (UFV-3), a highly lactose-fermenting yeast isolated from the Brazilian dairy industry. Genome Announcements. 2(6) e01136-14

- Tai-Leong D, Gupta A, Fen B H, Wan Guoqiang, Foong Yoong Li, HengPhon Too, Fook Tim Chew, Dietmar Werner Hutmacher (2007) Absolute quantification of gene expression in biomaterials research using real time PCR. Biomaterials. 28:203-210

- Vandesompele J., Kubsita M., Pfaffl MW. Reference gene validation software for improve normalization. In Real Time PCR: An Essential Guide $2^{\text {nd }}$ edition. Edited by: Edwards K, Logan J, Saunders N. Horizon Scientific Press; Norwich. 2002

- Vaudano E, Costantini A, Noti O, Garcia-Moruno E. (2010). An RT-qPCR approach to study the expression of genes responsible for sugar 
- assimilation during rehydration of active dry yeast. Food Microbiology. 27:802-807

- Wimborne M.P., Rickard P.A.D. (1978) Pectinolytic activity of Sacharomyces fragilis cultured in controlled environments. Biotechnology and Bioengineering. 20:231-242 


\section{ANEXOS}

\section{Anexo 1}

\section{Preparación de reactivos para actividad enzimática}

Reactivo 1 Nelson Somogyi

Solución A

En $800 \mathrm{ml}$ de agua destilada disolver $25 \mathrm{~g}$ de $\mathrm{Na}_{2} \mathrm{CO}_{3}$, añadir poco a poco hasta disolución total $25 \mathrm{~g}$ de $\mathrm{KNaC}_{4} \mathrm{H}_{4} \mathrm{O}_{6} \cdot 4 \mathrm{H}_{2} \mathrm{O}, 200 \mathrm{~g}$ de $\mathrm{Na}_{2} \mathrm{SO}_{4}$ y $20 \mathrm{~g}$ de $\mathrm{NaHCO}_{3}$. Aforar la solución a 1 litro con agua destilada. Conservar en frasco ámbar a temperatura ambiente

\section{Solución B}

En $200 \mathrm{ml}$ de agua destilada, añadir por las paredes del recipiente 4 gotas de $\mathrm{H}_{2} \mathrm{SO}_{4}$ concentrado, posteriormente, añadir $30 \mathrm{~g}$ de $\mathrm{CuSO}_{4} .5 \mathrm{H}_{2} \mathrm{O}$

Para obtener el reactivo final, mezclar $1 \mathrm{ml}$ de la solución B y $25 \mathrm{ml}$ de la solución A

Reactivo 2 Nelson Somogyi

\section{Solución A}

En $450 \mathrm{ml}$ de agua destilada añadir por las paredes del recipiente, lentamente, 21 $\mathrm{ml}$ de $\mathrm{H}_{2} \mathrm{SO}_{4}$ concentrado. Posteriormente añadir $25 \mathrm{~g}$ de $\left(\mathrm{NH}_{4}\right)_{6} \mathrm{Mo}_{7} \mathrm{O}_{24} \cdot 4 \mathrm{H}_{2} \mathrm{O}$.

Solución B

En $25 \mathrm{ml}$ de agua destilada disolver $3 \mathrm{~g} \mathrm{Na}_{3} \mathrm{AsO}_{4} .7 \mathrm{H}_{2} \mathrm{O}$

Mezclar lentamente y con agitación las soluciones A y B y aforar a $500 \mathrm{ml}$ con agua destilada. Calentar a $55^{\circ} \mathrm{C}$ durante $30 \mathrm{~min}$. Dejar enfriar y guardar en frasco ámbar. 


\section{Anexo 2}

Tabla 1. Valores de Ct obtenidos para la determinación de la eficiencia de amplificación del gen ACT1

\begin{tabular}{|c|l|c|}
\hline No. & \multicolumn{1}{|c|}{ Nombre } & Ct \\
\hline 1 & ACT D1 & 28.40 \\
\hline 2 & ACT D1.2 & 28.34 \\
\hline 3 & ACT D2 & 29.43 \\
\hline 4 & ACT D2.2 & 29.42 \\
\hline 5 & ACT D3 & 30.30 \\
\hline 6 & ACT D3.2 & 30.31 \\
\hline 7 & ACT D4 & 31.37 \\
\hline 8 & ACT D4.2 & 31.38 \\
\hline 9 & NTC ACT & \\
\hline & (Control negativo) & \\
\hline
\end{tabular}


Tabla 2. Valores de Ct obtenidos para la determinación de la eficiencia de amplificación del gen EPG

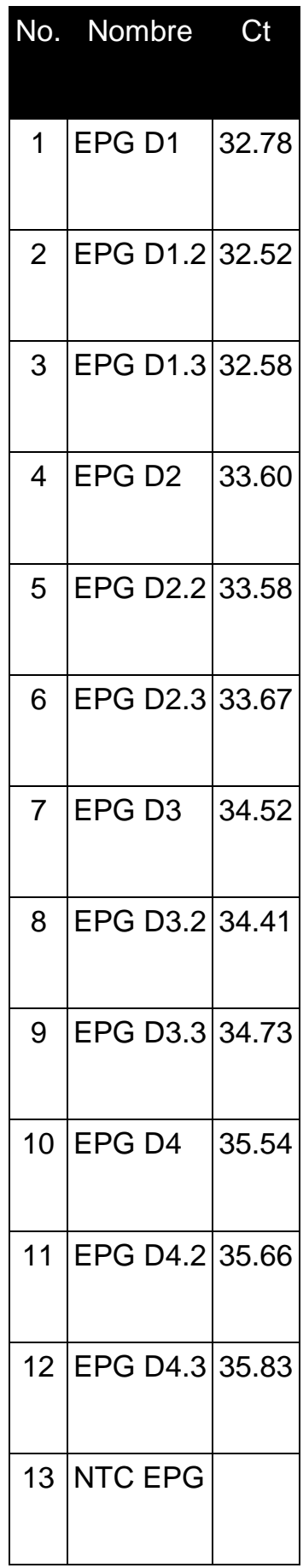


Tabla 3. Valores de Ct obtenidos para la determinación de la eficiencia de amplificación del gen $18 \mathrm{~S}$

\begin{tabular}{|c|l|c|}
\hline \multicolumn{2}{|c}{ No. Nombre } & Ct \\
\hline 1 & $18 S$ D1 & 13.87 \\
\hline 2 & 18 S D1.2 & 14.02 \\
\hline 3 & $18 S$ D1.3 & 13.71 \\
\hline 4 & $18 S$ D2 & 14.99 \\
\hline 5 & $18 S$ D2.2 & 14.77 \\
\hline 6 & $18 S$ D2.3 & 14.74 \\
\hline 7 & $18 S$ D3 & 15.90 \\
\hline 8 & $18 S$ D3.2 & 15.89 \\
\hline 9 & $18 S$ D3.3 & 15.82 \\
\hline 10 & $18 S$ D4 & 16.90 \\
\hline 11 & $18 S$ D4.2 & 16.88 \\
\hline 12 & $18 S$ D4.3 & 16.86 \\
\hline 13 & control negativo & \\
\hline
\end{tabular}




\section{Anexo 3.}

Tabla 1. Valores de Ct obtenidos en el PCR cuantitativo para el gen EPG en muestras del crecimiento anaerobio de K. marxianus CDBBL-278

\begin{tabular}{|l|l|l|l|}
\hline No. & \multicolumn{2}{|c|}{ Nombre } & \multicolumn{2}{|c|}{ Tipo de muestra } \\
\hline 1 & anaerobia epg & Desconocido & 26.72 \\
\hline 2 & anaerobia epg & Desconocido & 26.83 \\
\hline 3 & anaerobia epg & Desconocido & 26.99 \\
\hline 4 & anaerobia 18S & Desconocido & 9.89 \\
\hline 5 & anaerobia 18S & Desconocido & 9.82 \\
\hline 6 & anaerobia 18S & Desconocido & 9.59 \\
\hline 7 & anaerobia actina & Desconocido & 27.61 \\
\hline 8 & anaerobia actina & Desconocido & 27.46 \\
\hline 9 & anaerobia actina & Desconocido & 27.28 \\
\hline 10 & anaerobia epg & Desconocido & 28.10 \\
\hline 11 & anaerobia epg & Desconocido & 28.04 \\
\hline 12 & anaerobia epg & Desconocido & 28.34 \\
\hline 13 & anaerobia 18S & Desconocido & 10.69 \\
\hline 14 & anaerobia 18S & Desconocido & 10.64 \\
\hline 15 & anaerobia 18S & Desconocido & 12.11 \\
\hline 16 & anaerobia actina & Desconocido & 28.35 \\
\hline 17 & anaerobia actina & Desconocido & 28.43 \\
\hline 18 & anaerobia actina & Desconocido & 28.15 \\
\hline
\end{tabular}




\begin{tabular}{|l|l|l|l|} 
No. & \multicolumn{1}{|c|}{ Nombre } & \multicolumn{2}{c|}{ Tipo de muestra Ct } \\
\hline 20 & ntc actina & NTC & \\
\hline 21 & ntc 18S & NTC & \\
\hline 22 & neg (1) epg & Control negativo & \\
\hline 23 & neg (1) act & Control negativo & \\
\hline 24 & neg(1) 18S & Control negativo & \\
\hline 25 & neg (2) epg & Control negativo & \\
\hline 26 & neg (2) act & Control negativo & \\
\hline 27 & neg (2) 18S & Control negativo & 38.70 \\
\hline
\end{tabular}

Continuación tabla 1 
Tabla 2. Valores de Ct obtenidos en el PCR cuantitativo para el gen EPG en muestras de crecimiento aerobio de K. marxianus CDBBL-278

\begin{tabular}{|l|l|l|l|}
\hline \multicolumn{2}{|c|}{ No. } & \multicolumn{2}{c}{ Thbo } \\
\hline 1 & aerobia EPG & Desconocido & 33.54 \\
\hline 2 & aerobia epg & Desconocido & 33.85 \\
\hline 3 & aerobia epg & Desconocido & 33.35 \\
\hline 4 & aerobia act & Desconocido & 28.88 \\
\hline 5 & aerobia act & Desconocido & 28.91 \\
\hline 6 & aerobia act & Desconocido & 28.72 \\
\hline 7 & aerobia 18S & Desconocido & 12.15 \\
\hline 8 & aerobia 18S & Desconocido & 12.24 \\
\hline 9 & aerobia 18S & Desconocido & 12.26 \\
\hline 10 & aerobia epg & Desconocido & 30.76 \\
\hline 11 & aerobia epg & Desconocido & 30.66 \\
\hline 12 & aerobia epg & Desconocido & 30.87 \\
\hline 13 & aerobia act & Desconocido & 27.67 \\
\hline 14 & aerobia act & Desconocido & 27.51 \\
\hline 15 & aerobia act & Desconocido & 27.57 \\
\hline 16 & aerobia 18S & Desconocido & 11.51 \\
\hline 17 & aerobia 18S & Desconocido & 11.32 \\
\hline 18 & aerobia 18S & Desconocido & 11.29 \\
\hline 20 & negativo epg & Control negativo & \\
\hline
\end{tabular}




\begin{tabular}{|l|l|l|l|}
\hline No. Nombre & \multicolumn{2}{c|}{ Tipo } \\
\hline 21 & negativo 18S & Control negativo & 32.10 \\
\hline 22 & negativo epg & Control Negativo & \\
\hline 23 & negativo act & Control Negativo & \\
\hline 24 & negativo 18S & Control Negativo & 34.23 \\
\hline 25 & NTC epg & NTC (control negativo) & \\
\hline 26 & NTC act & NTC & \\
\hline 27 & NTC 18S & NTC & \\
\hline
\end{tabular}

Continuación tabla 2. 


\title{
12. PUBLICACIÓN CIENTÍFICA
}

Vol. 16, No. 2 (2017) 399-404

I- Revista Mexicana de Ingeniería Química

ENDOPOLYGALACTURONASE FROM Kluyveromyces marxianus CDBB-L-278: A

COMPARATIVE STUDY OF GENE EXPRESSION AND ENZYME ACTIVITY UNDER AEROBIC AND ANAEROBIC CONDITIONS

\section{ENDOPOLIGALACTURONASA DE Kluyveromyces marxianus CDBB-L-278: UN ESTUDIO COMPARATATIVO DE LA EXPRESIÓN DEL GEN Y DE LA ACTIVIDAD ENZIMÁTICA BAJO CONDICIONES AEROBIAS Y ANAEROBIAS}

\author{
A. Rivera-Noriega', A.E. Cruz-Guerrero', A.I. Morales-Estrada', L. Gómez-Ruiz', \\ M. López-Perez ${ }^{2}$, M. García-Garibay ${ }^{1.3 *}$ \\ 'Departamento de Biotecnología, Universidad Autónoma Metropolitana, Iztapalapa, Av. San Rafael Atlixco I86 Col. Vicentina, \\ Ciudad de México, 09340 México. \\ ${ }^{2}$ Departmento de Ciencias Ambientales, Universidad Autónoma Metropolitana, Lerma, Av. Hidalgo Poniente 46, Col. La \\ Estación, Lerma Edo, de México, 52006. \\ ${ }^{3}$ Departmento de Ciencias de la Alimentación, Universidad Autónoma Metropolitana, Lerma, Av. Hidalgo Poniente 46, Col. La \\ Estación, Lerma Edo. de México. 520006 México. \\ Received January 21, 2017; Accepted March 16, 2017
}

\begin{abstract}
The yeast strain Kluyveromyces marxianus CDBB-L-278 is an outstanding producer of endopolygalacturonase (EC. 3.2.1.15); it has been reported that its production is repressed under high dissolved oxygen tension. The expression of the endopolygalacturonase gene $(E P G)$ from this yeast was compared under both aerobic and anaerobic conditions and was related to the enzyme activity. Specific enzyme production under anaerobic conditions $\left(0.233 \mathrm{uPG} \mathrm{mg}^{-1}\right)$ was five times higher than that obtained under aerobic conditions $\left(0.048\right.$ uPG $\left.\mathrm{mg}^{-1}\right)$, demonstrating that anaerobic growth promotes the synthesis of endo-PG; relative quantification of EPG gene expression was 21.19 times higher in anaerobic culture, suggesting that production of endo-PG under anaerobic culture conditions is a consequence of the regulation of the EPG gene by dissolved oxygen saturation in the growth medium. Results point out that the higher production of endo-PG under anaerobic culture conditions is a consequence of the regulation of $E P G$ gene.

Keywords: dissolved oxygen regulation, endopolygalacturonase, EPG gene, Kluyveromyces marxianus, pectinase.

\section{Resumen}

La cepa de levadura Kluyvenomyces marxianus CDBB-L-278 es una extraordinaria productora de endopoligalacturonasa (EC. 3.2.1.15); se ha reportado que esta producción se reprime bajo una alta tensión de oxígeno. La expresión del gen de la endopoligalacturonasa ( $E P G)$ de esta levadura se comparó bajo condiciones aerobias y anaerobias y se relacionó con la actividad enzimática. La producción específica bajo condiciones anaerobias $\left(0.233 \mathrm{uPG} \mathrm{mg}^{-1}\right)$ fue cinco veces mayor que la actividad específica obtenida bajo condiciones aerobias $\left(0.048 \mathrm{uPG} \mathrm{mg}^{-1}\right)$, demostrando que el crecimiento anaerobio promueve la síntesis de la endo-PG; la cuantificación relativa de la expresión del gen EPG fue 21.19 veces mayor en el cultivo anaerobio, sugiriendo que la producción de la endopoligalacturonasa bajo condiciones anaerobias es consecuencia de la regulación del gen $E P G$ por las condiciones de saturación de oxígeno disuelto en el medio de cultivo. Los resultados demuestran que el aumento de la producción de endo-PG bajo condiciones anaerobias es consecuencia de la regulación del gen $E P G$.

Palabras clave: dissolved oxygen regulation, endopolygalacturonase, EPG gene, Kluyveromyces marxianus, pectinase.
\end{abstract}

Corresponding author. E-mail: jmgg(axanum, uam.mx

Tel. $+(52)(55) 5804-4720$

Publicado por la Academia Mexicana de Investigación y Docencia en Ingeniería Química A.C. 


\section{Introduction}

Kluyveromyces marxianus is a food grade yeast that has been used commercially for the production of single cell protein, alcohol, lactase and other goods, and its potential in food biotechnology is even wider (Fonseca et al.. 2008; Pérez et al., 2013; MartínezCorona et al.. 2015). For instance, it has a great potential in the production of enzymes (Espinoza et al., 1992), such as endo-polygalacturonase (endo-PG, EC. 3.2.1.15), an efficient pectin-degrading enzyme that cleaves the internal $\alpha-1,4-\mathrm{D}$ glycosidic linkages displaying macerative properties in vegetable tissues (Espinoza et al., 1992; Alimardani et al., 2011); this pectinase has been studied since long ago (Luh and Phaf, 1951; Luh and Phaf, 1954) and its use in the process of clarification of apple juice has been successfully demonstrated (Gómez-Ruiz et al., 1988). Particularly, the strain $K$. marxianus CDDB-L-278 has demonstrated to be an exceptional producer of endo-PG showing notably higher activity of pectinase than any other $K$. marxianus strain tested by our group (Espinoza et al., 1992). Production studies of endo-PG by $K$. marxianus have demonstrated that synthesis is repressed by dissolved oxygen (DO) in the growth medium (Wimborne and Rickard, 1978; García-Garibay et al., 1987). A later study by CruzGuerrero et al., (1999) found that $3.3 \mathrm{mgL}^{-1}$ of DO was the threshold for the repression of enzyme production in the strain $K$. marxianus CDBB-L-278.

Beyond these physiological studies, there are no reports regarding the expression of $E P G$ gene related to DO level in the medium; the current paper deals with the effect of DO in the expression of the EPG gene of $K$. marxianus CDBB-L-278 and the resulting activity of endo-PG. The study of the influence of DO on expression of $E P G$ gene is important in order to allow an improved control on the production of endoPG by the yeast, and will contribute to understand the interesting mechanism of gene control expression by oxygen, which, as far as we know, has not been studied.

\section{Materials and methods}

\subsection{Strain}

K. marxianus CDBB-L-278 was obtained from de Culture Collection of the Centre for Research and Advanced Studies (CINVESTAV) at the National Polytechnic Institute, Mexico City. This strain was maintained on potato-dextrose agar slants (Bioxon. Mexico).

\subsection{Culture medium}

A synthetic medium was used containing (g 100 $\mathrm{ml}^{-1}$ ): glucose 2, $\left(\mathrm{NH}_{4}\right)_{2} \mathrm{SO}_{4} 0.2, \mathrm{KH}_{2} \mathrm{PO}_{4} \quad 0.05$, $\mathrm{MgSO}_{4} 0.05$ and yeast extract 0.2 ; glucose and salts were from J.T. Baker (Mexico), and yeast extract was from Bioxon (Mexico). Medium $\mathrm{pH}$ was adjusted to 5 and autoclaved for $15 \mathrm{~min}$ at $121^{\circ} \mathrm{C}$.

\subsection{Culture conditions}

Inoculum was prepared in Erlenmeyer flasks containing $50 \mathrm{ml}$ of culture medium in a New Brunswich G-24 rotatory shaker $\left(200 \mathrm{rpm}, 30^{\circ} \mathrm{C}\right)$ and growth 16-18 h. Fermentations were conducted in a New Brunswick BioFlo IIc fermenter with I I of medium at $30^{\circ} \mathrm{C}$ during $9 \mathrm{~h}$, using $50 \mathrm{ml}$ of inoculum with an optical density of 1.8 (measured at $650 \mathrm{~nm}$ ). Aerobic fermentations were performed with an air flow of $2 \mathrm{vvm}$; the dissolved oxygen saturation was automatically controlled at $60 \%$ by adjustments in the stirring rate. Anaerobic fermentations were performed without air flow and a stirring rate of 50 rpm. Samples of $15 \mathrm{ml}$ were taken at $0,3,6$ and $9 \mathrm{~h}$; biomass was determined by turbidity at $650 \mathrm{~nm}$ and reported as dry weight basis biomass using a standard curve as reported by Garcia-Garibay et al., (1987); samples were centrifuged at $3020 \mathrm{~g}$ for $5 \mathrm{~min}$, and enzymatic activity was measured in the supernatant; cells were diluted in $1 \mathrm{ml}$ of sterile DEPC-water (diethyl pyrocarbonate, Sigma) and maintained at $70^{\circ} \mathrm{C}$ for RNA extraction.

\subsection{Adjustment of yeast growth}

Experimental data of yeast growth were adjusted by Ec. (1) according to the logistic model of VelhurstPearl using the Solver tool of Excel (Microsoft Office 2007).

$$
X(t)=\frac{X_{\max }}{1+\frac{X_{\max }-X_{o}}{X_{o}} \exp ^{-\mu t}}
$$

Where:

$X_{o}=$ initial biomass concentration $\mathrm{g} \mathrm{I}^{-1}$

$X_{\max }=$ maximal biomass concentration $\mathrm{g}^{-1}$

$\mu=$ specific growth rate $\mathrm{h}^{-1}$

$t=$ time $\mathrm{h}$ 


\subsection{Endo-PG activity}

It was measured by the increase in reducing groups release from a polygalacturonic acid solution (Sigma) (García-Garibay et al., 1987). One unit of endo-PG was defined as the amount of enzyme which releases $1 \mu \mathrm{mol}$ of reducing groups per minute (uPG $\mathrm{ml}^{-1}$ ). Specific activity was defined as the enzymatic activity

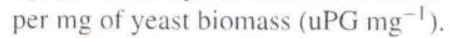

\subsection{RNA isolation and reverse transcription}

RNA was isolated from $9 \mathrm{~h}$ aerobic and anaerobic culture samples using Purelink RNA minikit (Ambion), following manufacturer's instructions. Cell disruption was done using 400-600 $\mu \mathrm{m}$ acid washed glass beads (Sigma). RNA quality was evaluated through 1\% agarose gel electrophoresis performed in a Thermo EC Minicell chamber (USA) using constant voltage of $60 \mathrm{~V}, 90 \mathrm{~min}$; the running buffer was TAE IX prepared with DEPECwater; gels were stained with GelRed (Biotium, USA) and the bands were visualized by means of an image analyzer (MiniLumi DNR, Bio-Imaging Systems Ltd, Jerusalem, Israel). RNA purity was also confirmed measuring the absorbance ratio at 260/280, with NanoDrop 2000/2000c (Thermo Scientific): absorbance at $260 \mathrm{~nm}$ was used to determine RNA concentration.

RNA samples were treated with RQI RNaseFree DNase (Promega) to remove any residual DNA contamination; total mixture reaction $(20 \mu \mathrm{l})$ contained 100 ng of total RNA, DNase buffer and DEPC-water; it was incubated at $30^{\circ} \mathrm{C}, 1 \mathrm{~h}$; then buffer DNAsa stop was added and was incubated at $65^{\circ} \mathrm{C}, 10 \mathrm{~min}$. Conventional PCR was performed to check the absence of genomic DNA (gDNA). When necessary, the DNAse treatment was repeated. RNA was converted into cDNA (complementary DNA) using Quantitec Reverse Transcription Kit (Qiagen Hilden, Germany) incubating at $42^{\circ} \mathrm{C}, 30 \mathrm{~min}$ and then at $95^{\circ} \mathrm{C}$ for $3 \mathrm{~min}$.

\subsection{Optimization of reaction conditions for quantitative real time PCR ( $q P C R)$}

The oligonucleotide primers were designed by Integrated DNA technologies (IDT https://www idtdna.com/). The following sequences were considered for primer design: GenBank accession numbers AY426825, the $K$. marxianus EPG1-2 gene: and as normalizing genes: AB054675, the $K$. marxianus $18 \mathrm{~S}$ gene, and $\mathrm{AJ} 389078$, the $K$. marxianus actin gene (ACT1).

Primer specificity was checked by end point PCR with 10-25 ng of gDNA as template amplifying a 163 bp fragment, sequence fw primer (cac ttc ttg tcc aac act atc t) and rw primer (ctg taa gcg gaa gag tca ac) for the EPG target gene; a 123 bp fragment, sequence fw primer (aat tcc agc tcc agt age gt) and rw primer (gaa gga aag atc cgg ttg aa) for the $18 \mathrm{~S}$ normalized gene; and a $125 \mathrm{bp}$ fragment, sequence fw primer (aag aaa $\operatorname{tgc}$ aaa $\mathrm{ccg} \mathrm{ctt} \mathrm{ct}$ ) and rw primer (aac aga tgg tgg aac aaa $g c)$ for the ACTI gene. Reaction conditions were $94^{\circ} \mathrm{C}, 2 \mathrm{~min}$ for denaturation step; 30 cycles at $94^{\circ} \mathrm{C}$, $1 \mathrm{~min}$ for melting; temperature gradient for annealing step $52-60^{\circ} \mathrm{C}$, I $\mathrm{min}$ for each primer; $72^{\circ} \mathrm{C}, 5 \mathrm{~min}$ for extension step. After the annealing temperature gradient testing, only at $54^{\circ} \mathrm{C}$ a single amplification product with the expected size was detected; hence. this temperature was selected to perform RT-PCR.

In order to check the specificity of the TaqMan probes (Applied Biosystems) amplification reactions were performed by triplicate RT-PCR (Rotor gene 5 . Corbett Life Science) using both the specific primers and the designed probes ( $E P G$ gene FAM-agg tag caa ggt cec aat cac caa-TAMRA; $18 \mathrm{~S}$ gene FAM-acc ggc caa cca gac cca aa-TAMRA; ACT1 gene FAM-cca atg gtg ata act tga cca tct ggc-TAMRA). Reaction volume was $25 \mu \mathrm{l}$ with the following reagents: TaqMan PCR Universal master mix $1 \mathrm{X}$. primers $0.15 \mu \mathrm{M}$. probe 0.05 $\mu \mathrm{M}$ and cDNA $4 \mu \mathrm{l}$. Reaction conditions were $50^{\circ} \mathrm{C}, 2$ min; $95^{\circ} \mathrm{C}, 10 \mathrm{~min}$ and 40 cycles at $95^{\circ} \mathrm{C}, 15 \mathrm{~s}$ and $54^{\circ} \mathrm{C} .1 \mathrm{~min}$.

The efficiency of EPG, 18S and ACTI genes was determined in aerobic growth conditions using four dilutions of cDNA of known concentration. The amplification efficiency, the correlation coefficient and the slope were calculated by the Rotor-gene 2000 software version 4.7 (Corbett Life Technology).

\subsection{Relative quantification of EPG gene}

Quantification was done from the cDNA; samples were amplified by triplicate, and a negative control of reactives (without cDNA) was done. Fluorescence threshold for all the samples was 0.05 RFU. The threshold reaction cycle of the product was defined as Ct. Relative expression rate of the target gene was calculated according to Hellemans et al., (2007). 


\subsection{Statistical analysis}

A t-Student test was performed $(P<0.05)$ to compare the total and specific enzymatic activity between the aerobic and anaerobic fermentations using Excel (Microsoft Office 2007).

\section{Results and discussion}

\subsection{Growth and endo-PG activity under aerobic and anaerobic conditions}

Fig. I shows that maximal growth of $K$. marxianus CDBB-L-278 under aerobic conditions $(60 \%$ DO saturation) was $2.56 \mathrm{mg} \mathrm{ml}^{-1}$, while under anaerobic conditions was $0.71 \mathrm{mg} \mathrm{ml}^{-1}$. The microbial growth adjusted to the logistic model lead to a correlation of 0.97 for aerobic conditions and 0.99 for anaerobic conditions. Additionally, specific growth rate $(\mu)$ was $0.85 \mathrm{~h}^{-1}$ and $0.53 \mathrm{~h}^{-1}$ for aerobic and anaerobic conditions respectively, suggesting that aerobic conditions led to a more favorable production and rate of biomass. In spite that Fig. 2A does not show difference for total enzymatic activity between aerobic and anaerobic cultures, considering the remarkable difference in growth, the specific enzymatic activity was five times higher under anaerobic conditions ( 0.233 vs. 0.048 uPG mg biomass $^{-1}$ ) (Fig. 2B). These results demonstrated that under anaerobic growth the synthesis of endo-PG was promoted as reported previously (Wimborne and Rickard 1978; GarcíaGaribay et al., 1987; Cruz-Guerrero et al., 1999).

\subsection{Quantitative real time PCR (qPCR)}

Amplification efficiency for EPG gene was 0.98 $(r=0.9948)$ and a slope of -3.34 ; amplification efficiency data and the slope for $18 \mathrm{~S}$ and $\mathrm{ACT} 1$ genes were $0.99(\mathrm{r}=0.997)$ and -3.34 ; and $1.01(\mathrm{r}=0.999)$ and -3.29 respectively, suggesting a good amplification efficiency (Sellars et al., 2007) in all cases. The 18S gene and the ACTI gene were chosen as normalized genes because they did not show any differences in expression under the studied growth conditions.

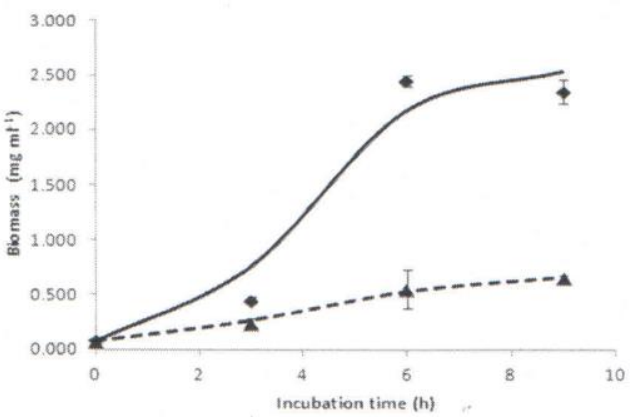

Fig. 1. Cell growth of Kluyveromyces marxianus CDBBL-278 in anaerobic (filled triangle) and aerobic (filled diamond) conditions. Dotted line represents anaerobic growth while solid line represents aerobic growth data adjusted to the logistic model.

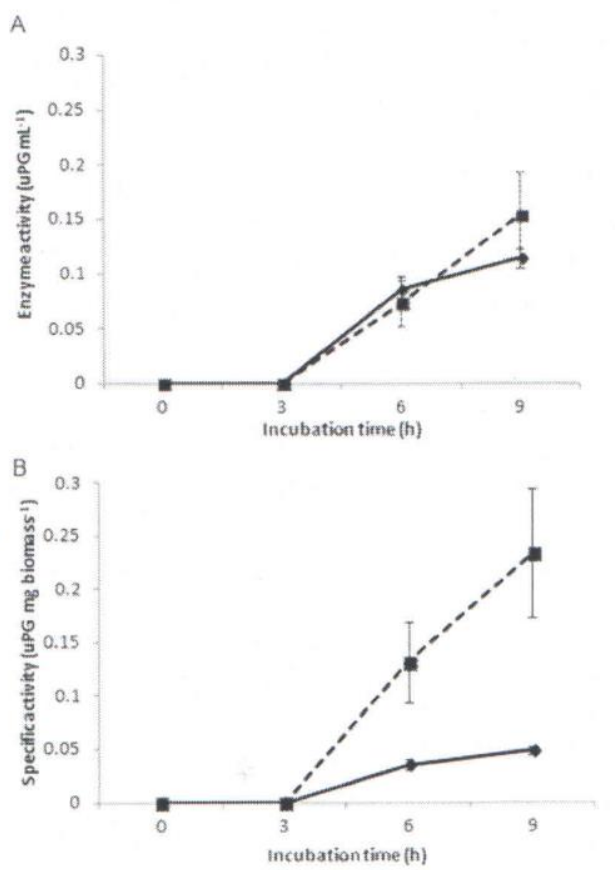

Fig. 2. Enzymatic activity (a) and specific enzymatic activity (b) from $K$. marxianus CDBB-L-278 in aerobic (filled diamond, solid line) and anaerobic growth (filled square, dotted line). 


\subsection{Quantification of EPG gene expression under aerobic and anaerobic growth conditions}

The $\mathrm{Ct}$ value obtained at $9 \mathrm{~h}$ for anaerobic growth was $27.94 \pm 0.87$. while that for the aerobic growth at the same time was $32.69 \pm 1.34$; as the Ct value is inversely proportional to the initial value of cDNA, this means a higher expression of the $E P G$ gene under anaerobic conditions. These results confirm that diminishing DO saturation in the growth medium leads to an induction of the gene expression, resulting in an increase of endo-PG activity. Relative quantification of $E P G$ gene expression was calculated by the equation reported by Hellemans et al. (2007); results showed an increase of 21.19 times of EPG gene expression under anaerobic conditions with respect to the aerobic ones. Due to the increment in EPG gene expression of $K$. marxianus observed under anaerobic conditions, it could be supposed that this regulation takes place at transcriptional level; namely, it could be regulated by some factors related to the adaptation of the yeast to anaerobic growth conditions or stress factors, such as the case of the PGUI gene in Saccharomyces cerevisiae which encodes an endo-PG, whose expression has been observed to be regulated by transcriptional factors that also regulate genes responsible for flocculation and pseudomycelium formation under starvation stress conditions (Louw et al., 2010).

It was also observed that the specific activity of endo-PG increased five times at $9 \mathrm{~h}$ under anaerobic conditions compared with aerobic conditions, which is related to the expression of the gene. The fact that gene expression level is higher than the increment in enzymatic activity under anaerobic conditions, could be due to translational aspects denoting that not all the mRNA is translated to protein (Shah et al., 2013).

Wimborne and Rickard (1978) established that the production of endo-PG by $K$. marxianus is partially constitutive, since it is repressed by aerobic conditions, while Schwan et al. (1996) pointed out that it is constitutive and not subject to carbone catabolite repression. The expression of the $E P G$ gene is rather a complex question, since it is repressed by oxygen, but has been demonstrated to be induced by pectin under aerobic conditions (García-Garibay et al., 1987); therefore, it worth to continue studying the several aspects involved in the repression-activation of this gene, which seems to be unique and multifactorial.

\section{Conclusions}

Anaerobic growth conditions resulted in the promotion of endo-PG activity as well as of the expression of $E P G$ gene; these results point out that the higher production of endo-PG under anaerobic culture conditions is a consequence of the regulation of $E P G$ gene by DO saturation in the growth medium.

\section{Acknowledgement}

Authors Alicia Rivera-Noriega acknowledge a doctoral grant and Aurea I. Morales-Estrada a postdoctoral fellowship from the National Council of Science and Technology (CONACyT), Mexico.

\section{References}

Alimardani-Theuil, P., Gainvors-Claisse, A., and Duchiron, F. (2011). Yeasts: An attractive source of pectinases-From gene expression to potential applications: A review. Process Biochemistry 46, 1525-1537.

Cruz-Guerrero, A., Bárzana, E., García-Garibay. M., and Gómez-Ruiz, L. (1999). Dissolved oxygen threshold for the repression of endo-polygalacturonase production by Kluyveromyces marxianus. Process Biochemistry 34, 621-624.

Espinoza, P., Bárzana, E., García-Garibay, M., and Gomez-Ruiz, L. (1992). Evaluation of Kluyveromyces marxianus for the production of lactase simultaneously to pectinase or inulinase. Biotechnology Letters 14, 1053-1058.

Fonseca, G.G., Heinzle, E., Wittmann, C.. and Gombert. A.K. (2008). The yeast Kluyveromyces marxianus and its biotechnological potential. Applied Microbiology and Biotechnology 79, 339-354.

García-Garibay, M., Gómez-Ruiz, L., and Bárzana, E. (1987). Studies on the simultaneous production of single-cell protein and endopolygalacturonaase from Kluyveromyces fragilis. Biotechnology Letters 9, 411-416.

Gómez-Ruiz, L., García-Garibay, M., and Bárzana, E. (1988). Utilization of endopolygalacturonase from Kluyveromyces fragilis in the clarification of apple juice. Journal of Food Science 53, 1236-1237, 1240. 
Rivera-Noriega et al./ Revista Mexicana de Ingenieria Química Vol. 16, No. 2 (2017) 399-404

Hellemans, J., Mortier, G., De Paepe, A., Speleman, F., and Vandesompele, J. (2007). qBase relative quantification framework and software for management and automated analysis of realtime quantitative PCR data. Genome Biology 8 , R19.

Louw, C., Young, P.R., Van Rensburg, P., and Divol, B. (2010). Regulation of endopolygalacturonase activity in Saccharomyces cerevisiae. FEMS Yeast Research 10, 44-57.

Luh, B.S., and Phaf, H.J. (1951). Studies on polygal acturonase of certain yeast. Archives of Biochemistry and Biophysics 33, 212- 227.

Luh, B.S., and Phaf, H.J. (1954). Properties of yeast polygalacturonase. Archives of Biochemistry and Biophysics 48, 23-37.

Martinez-Corona, R., González-Hernández, J.C., Radames-Trejo, V., Cortés-Penagos, C., Chávez-Parga, M.C., and Zamudio-Jaramillo, M.A. (2015). Effect of initial substrate concentration and agitation on xylitol production by fermentation of hydrolyzed tamarind seed media with Kluyveromyces marxianus. Revista Mexicana de Ingeniería Química 14, 393-403.

Pérez, E., González-Hernández, J.C., ChávezParga, M.C., and Cortés-Penagos, C. (2013).
Caracterización fermentativa de levaduras productoras de etanol a partir de jugo de Agave cupreata en la elaboración de mezcal. Revista Mexicana de Ingenieria Química 12, 451-461.

Schwan, R.F., Cooper, R.M., and Wheals, A.E. (1996). Endopolygalacturonase of the yeast Kluyveromyces marxianus is constitutive, highly active on native pectin and is the main extacellular protein. In: Pectins and Pectinases, Proceedings of an International Symposium, (J. Visser and A.G.J. Voragen, eds.), Pp. 861-868. Elsevier Science Publisher, New York.

Sellars, M.J., Vuocolo, T., Leeton, L.A., Coman, G.J., Degnan, B.M., and Preston, N.P. (2007). Real time RT-PCR quantification of kuruma shrimp transcripts: A comparison of relative and absolute quantification procedures. Journal of Biotechnology 129, 391-399.

Shah, P., Ding, Y., Niemczyk, M., Kudla, G., and Plotkin, J.B. (2013). Rate-limiting steps in yeast protein transiation. Cell 13, 1589-1601.

Wimborne, M.P., and Rickard, P.A.D. (1978). Pectinolytic activity of Saccharomyces fragilis cultured in controlled environments. Biotechnology and Bioengineering 20, 231-242. 